\title{
IntechOpen
}

\section{Modern Slavery and Human Trafficking}

Edited by Jane Reeves

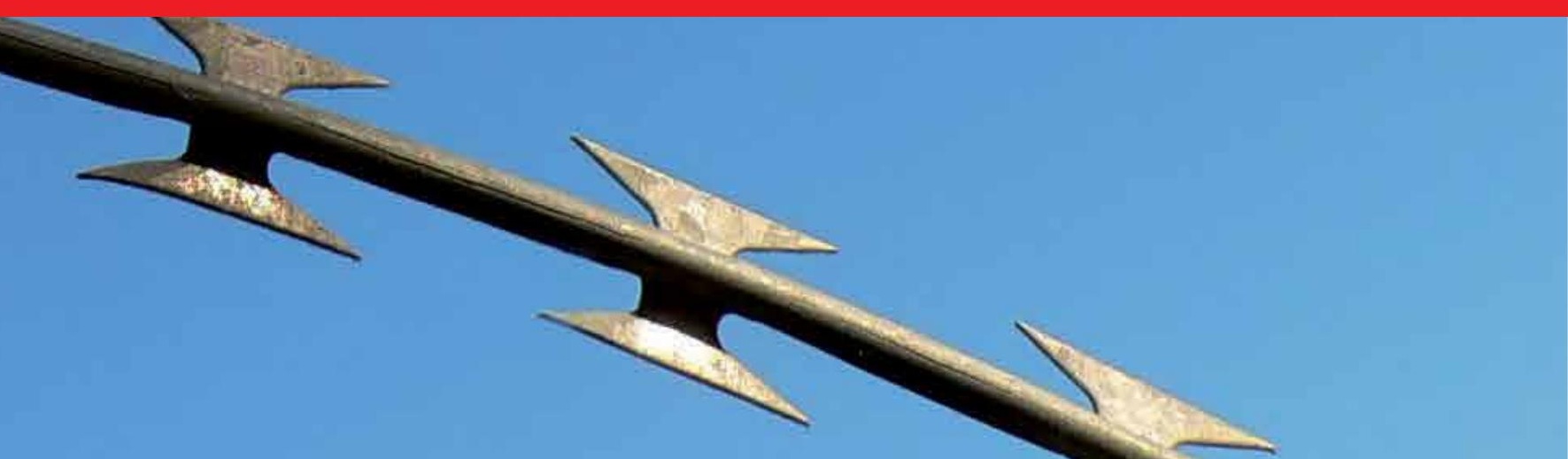





\section{Modern Slavery and Human Trafficking \\ Edited by Jane Reeves}



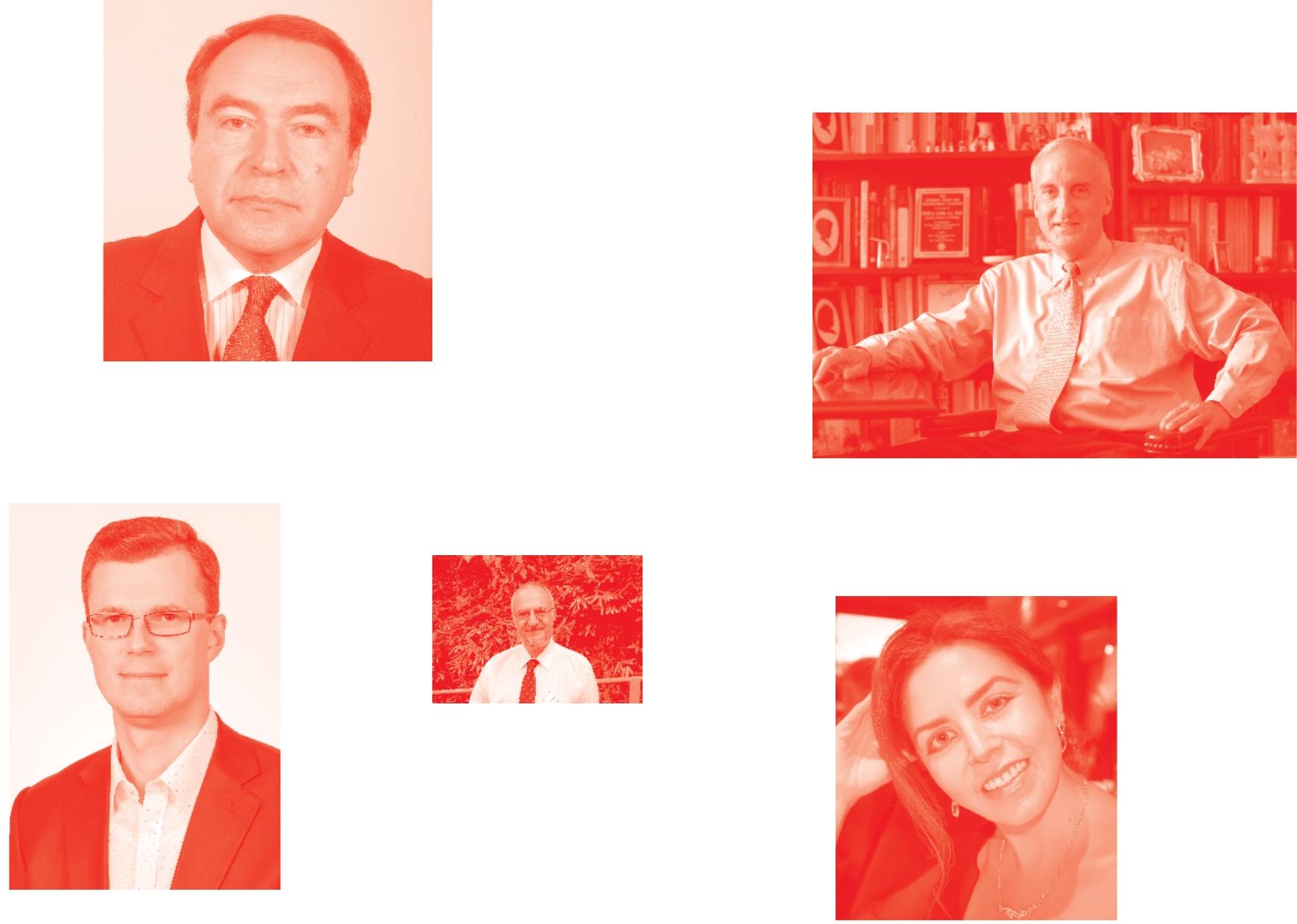

Supporting open minds since 2005
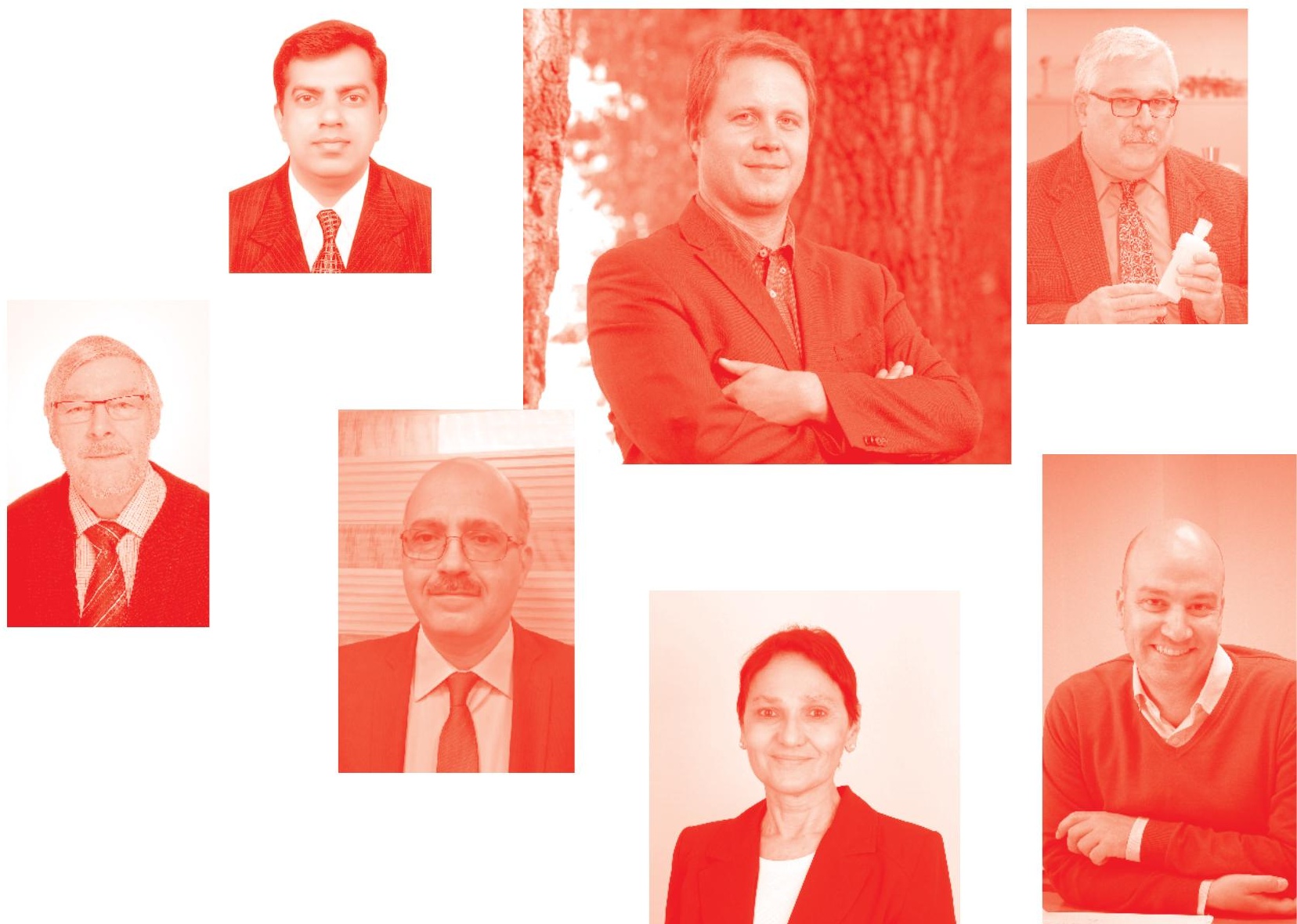
Modern Slavery and Human Trafficking

http : //dx. doi . org/10.5772/intechopen. 77619

Edited by Jane Reeves

\section{Contributors}

Chris Jones, Adewale Olutola, Paul Bello, Giuseppe Patisso, Fausto Ermete Carbone, Jennifer Okeke, Rosaleen McElvaney, Mel Duffy, Waldimeiry Correa Da Silva, Carla Cingorlani, Paula Cristina Martins

๑) The Editor(s) and the Author(s) 2021

The rights of the editor(s) and the author(s) have been asserted in accordance with the Copyright, Designs and Patents Act 1988. All rights to the book as a whole are reserved by INTECHOPEN LIMITED . The book as a whole (compilation) cannot be reproduced, distributed or used for commercial or non-commercial purposes without INTECHOPEN LIMITED's written permission. Enquiries concerning the use of the book should be directed to INTECHOPEN LIMITED rights and permissions department (permissions@intechopen.com).

Violations are liable to prosecution under the governing Copyright Law .

\section{(cc) BY}

Individual chapters of this publication are distributed under the terms of the Creative Commons Attribution 3. (0 Unported License which permits commercial use, distribution and reproduction of the individual chapters, provided the original author(s) and source publication are appropriately acknowledged. If so indicated, certain images may not be included under the Creative Commons license. In such cases users will need to obtain permission from the license holder to reproduce the material. More details and guidelines concerning content reuse and adaptation can be found at http : //www . intechopen . com/copyright-policy. html.

Notice

Statements and opinions expressed in the chapters are these of the individual contributors and not necessarily those of the editors or publisher. No responsibility is accepted for the accuracy of information contained in the published chapters. The publisher assumes no responsibility for any damage or injury to persons or property arising out of the use of any materials, instructions, methods or ideas contained in the book.

First published in London, United Kingdom, 2021 by IntechOpen

IntechOpen is the global imprint of INTECHOPEN LIMITED, registered in England and Wales, registration number: 11086078 , 5 Princes Gate Court, London, SW7 2QJ, United Kingdom Printed in Croatia

British Library Cataloguing-in-Publication Data

A catalogue record for this book is available from the British Library

Additional hard and PDF copies can be obtained from orders@intechopen.com

Modern Slavery and Human Trafficking

Edited by Jane Reeves

p. cm.

Print ISBN 978-1-78923-853-2

Online ISBN 978-1-78923-854-9

eBook (PDF) ISBN 978-1-83880-483-1 


\section{We are IntechOpen, \\ the world's leading publisher of Open Access books}

\section{Built by scientists, for scientists}

\section{$5,100+$}

Open access books available

156

Countries delivered to
$127,000+$

International authors and editors
$145 \mathrm{M}+$

Downloads

Our authors are among the

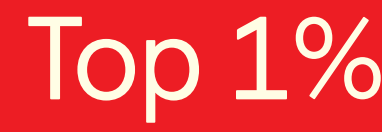

most cited scientists

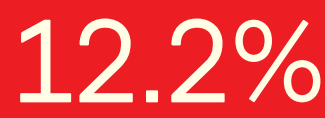

Contributors from top 500 universities

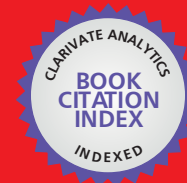

WEB OF SCIENCE ${ }^{\mathrm{TM}}$

Selection of our books indexed in the Book Citation Index in Web of Science ${ }^{\mathrm{TM}}$ Core Collection (BKCI)

Interested in publishing with us?

Contact book.department@intechopen.com

Numbers displayed above are based on latest data collected.

For more information visit www.intechopen.com

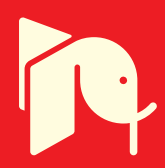





\section{Meet the editor}

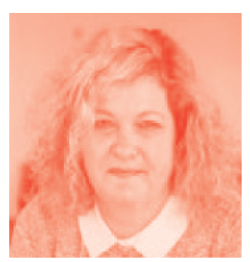

Jane Reeves is an Emeritus Professor in teaching-learning and innovation at the Centre for Child Protection and was one of the founding Directors of the Centre. She is a qualified social worker. As a Co-Director of CCP she worked with many stakeholders to co-write immersive simulations that tackle complex child protection issues including sexual abuse ('Rosie 1'); neglect ('Rosie 2'); radicalization and extremism ('Zak'; 'Behind Closed Doors'); paedophilia ('Elliot'); child sexual exploitation ('Looking out for Lottie'); and 'Rosie goes to court'. The simulations are widely used across the UK and internationally by professionals and young people. She has led innovative projects funded by the DfE and Innovate UK and has worked on an Erasmus project with the University of Stirling, protecting children across Europe through modernising the social work curriculum. She is currently leading a global EVAC Project on online sexual exploitation and trafficking which is designing a serious digital game for children and young people in Thailand and Cambodia. 



\section{Contents}

$\begin{array}{lll}\text { Preface } & \text { XIII }\end{array}$

Chapter 1

South African Perspective on Sexual Slavery, Sex Work and Exploitation

by Chris Jones

Chapter 2

The Conundrum of Human Trafficking in Africa

by Paul O. Bello and Adewale A. Olutola

Chapter 3

Labour Trafficking and Exploitation in Rural Andalusia

by Waldimeiry Correa da Silva and Carla Cingolani

Chapter 4

Slavery and Slave Codes in Overseas Empires

by Giuseppe Patisso and Fausto Ermete Carbone

Chapter 5

Traffickers: Are They Business People, Psychopaths or Both?

by Jennifer Okeke, Mel Duffy and Rosaleen McElvaney

Chapter 6

Child Trafficking: The Construction of a Social Problem

by Paula Cristina Martins 



\section{Preface}

This edited volume is a collection of reviewed and relevant research chapters concerning the developments within the modern slavery and human trafficking field of study. The book includes scholarly contributions by various authors and edited by a group of experts pertinent to modern slavery and human trafficking topics. Each contribution comes as a separate chapter complete in itself but directly related to the book's topics and objectives.

The book includes chapters dealing with the following topics: "South African Perspective on Sexual Slavery, Sex Work and Exploitation", "The Conundrum of Human Trafficking in Africa", "Slavery and Slave Codes in Overseas Empires", “Traffickers: Are They Business People, Psychopaths or Both?”, "Labour Trafficking and Exploitation in Rural Andalusia", and "Child Trafficking: The Construction of a Social Problem".

The target audience comprises scholars and specialists in the field. 



\title{
South African Perspective on Sexual Slavery, Sex Work and Exploitation
}

\author{
Chris Jones
}

\begin{abstract}
After millennia, formal slavery in most jurisdictions worldwide eventually came to an end by the middle of the nineteenth century. Yet, all kinds of trapped forms of labour took its place, among others sexual slavery-one of the most serious organised crimes of our time and historically one of the oldest human practices of gender inequality and exploitation. This chapter starts with broad, introductory remarks on the possible causes of sexual slavery and exploitation as well as what we as a society can do to collectively address this pressing issue. It then looks in more detail at the extent of this problem in South Africa. The chapter then moves on to consider antihuman trafficking legislation in South Africa and what it entails; a distinction is made between sexual slavery and sex work; and the reasons, effects and value of decriminalising sex work are referred to. A short account is given of the mythologised life of Sara Baartman, one of the most famous, but also least known, South African woman of her day and what we can learn from her about gender inequality, sexual slavery and exploitation.
\end{abstract}

Keywords: sexual slavery, exploitation, antihuman trafficking legislation, sex work, decriminalisation of sex work, Sara Baartman, gender

\section{Introduction}

Sexual slavery and exploitation have been a worldwide problem for a very long time. This specifically applies to women and children due to factors which include a lack of employment, education and opportunities to improve their living conditions [1].

Social instability and conflict drive people to embrace desperate measures in order to survive. Despair, hunger, frustration and anxiety render some women vulnerable and gullible to the empty promises made by traffickers. Instead of promised jobs or study opportunities, they find themselves forced into servitude or prostitution.

Syndicates that deal with human trafficking consist of greedy, unscrupulous, predatory, self-centred violent men and women who are involved in coercion, fraud and deception. They commit trafficking offences with impunity. Trafficking is their source of income. They are daring and slippery. They avoid being arrested at all costs. These are men for whom honour and nobility are meaningless words [1]. 
Despite human solidarity and a common humanity, gender inequality globally flourishes, and many women experience exclusion, marginalisation, denigration, abuse and violence at the hands of "macho" men [1]. Patriarchy and male domination thrive in many societies. Evidence strongly suggests that there are men who experience entertainment and self-gratification at the expense of women, while women and girls, who become the victims of these men, experience shame, humiliation, indignity, loss of self-respect and meaninglessness [1].

Statistically, according to Kristof and Wudunn, more "women and girls are now shipped into brothels each year than were slaves from Africa shipped each year into slave plantations in the early eighteenth and nineteenth centuries" [2]. According to a Global Report on Trafficking in Persons by the United Nations Office on Drugs and Crime (UNODC), “[a]bout 23,000 victims trafficked for sexual exploitation were detected and reported between 2012 and 2014" [3]. Of these victims trafficked for sexual exploitation during this period in 71 countries, $96 \%$ were female: women or girls [3]. In this respect it is important to refer to the Sustainable Development Goals of the United Nations that explicitly addresses in its 169 associated targets the elimination (Target 5.2) of "all forms of violence against all women and girls in the public and private spheres, including trafficking and sexual and other types of exploitation" [4] by 2030.

It is argued [1] that we should collectively call for responsibility, greater awareness and participative engagement in order to tackle this multi-faceted problem of slavery for sexual exploitation. Leaders must constantly be called upon to prevent trafficking to the extent they can and to keep perpetrators accountable. According to Tlhagale the "enslavement of human beings, especially women and children, in this day and age, simply weakens humanity's claim to human progress and civilisation" [1].

Following these introductory remarks, the aim of this chapter is to explore the extent of sex slavery, sex work and exploitation in South Africa. It evaluates the latest statistics available and deals with the most reliable resources on this matter. There are however weaknesses in South African literature in this respect. There is a shortage of primary research and data regarding this issue [5], although this is slowly changing. Popular publications in this regard were mostly avoided due to doubtful information they may contain. Part of the aim of this chapter is thus to gain a foundational overview of sex slavery and exploitation in South Africa. Definitions regarding sex work and sex slavery are briefly discussed, and the antitrafficking law in South Africa is looked at-in order to protect the victims of sex slavery and prosecute the perpetrators. The necessity of decriminalising sex work in South Africa, among others, to respect the dignity of sex workers, is also discussed. Then Sara Baartman, a famous South African woman on her day, who was seen by Westerners as "attractive" and primitive, while reflecting their fears and suppressed desires, is brought into the discussion. Who was this illusive figure who confronts us with gender inequality and violence, and what can we learn from her narrative? This chapter demonstrates how, despite global interconnectedness and human solidarity, gender inequality and slavery for sexual exploitation are still a reality. It shows how essential it is for the way forward to design more extensive and representative investigations (although difficult) into sexual slavery and exploitation in South Africa in order to address this problem more effectively.

The chapter starts with the contextualisation and extent of sexual slavery in South Africa.

\section{The extent of trafficking in South Africa}

There are organisations and individuals who claim that as many as 30,000 children are "trafficked" into the sex trade every year in South Africa. According 
to media articles (The Times and Pretoria News), 50\% of these 30,000 children trafficked and prostituted annually in South Africa are under the age of 14 . This claim was attributed to Rawlins of Freedom Climb, "a project that works with trafficked people around the globe" [6]. In May 2013, Stafford, who is the coordinator for the Salvation Army's anti-trafficking campaign, said that in "2010, we had 20,000-30,000 children prostituted-now the figure stands at 45000" [7]. In the run-up to the Soccer World Cup in South Africa in 2010, aid groups estimated that some 38,000 children were trapped in the sex trade in South Africa [6]. According to an IOL News article it was believed that 40,000 women and children were trafficked during the World Cup in Germany in 2006, and it was estimated that close to 100,000 could have been affected in 2010 during the Soccer World Cup in South Africa. But research showed that there had only been five cases directly linked to the Germany Soccer World Cup [8]. Although there was anxiety that sex trafficking would remarkably increase with the advent of the 2010 Soccer World Cup in South Africa, "little attention was paid to the fact that research showed no changes to the sex industry. In fact, not a single case of human trafficking was found by the Department of Justice during the World Cup period" [9].

Overestimated claims in this respect are not new. Gould ${ }^{1}$, a South African researcher at the Institute for Security Studies and author of a book outlining research about the sex work industry, suggests no one knows "for certain the size of the problem, and argued that the 40000 figure was 'unfounded"' [10]. This was supported by Khokhar from the International Organisation for Migration who said this "figure had been nothing but 'hype"” [10]. Pharaoh states that one has to look critically at this data. She refers to Kelly who alludes to

the possibility of what have been called "advocacy numbers", where estimates are inflated (if not deliberately, then through conscious neglect of sound methodological practice) for awareness and fundraising purposes. It could also simply be that the issue is an emotive one and that sensationalism sells $[5,11]$.

According to Gould and Fick, research on trafficking especially in South Africa is "frequently methodologically weak and resorts to the reiteration of commonly agreed myths about the nature of the activity" [12]. For them the question arose: "is "trafficking' a useful lens through which to consider issues of exploitation and abuse in the sex work industry?" [12]. In total their research “identified eight women (of 164 canvassed) who could possibly be considered victims of trafficking" [12]. The research was carried out to "gather data about the sex industry in Cape Town and about any evidence of human trafficking into the industry" [13]. They came to the following conclusion: "We acknowledge that some cases of trafficking may have escaped our notice, but on the strength of the evidence we gathered we have to conclude that in Cape Town the incidence of trafficking for the purposes of prostitution is very low" [12].

The United Nations Office on Drugs and Crime's 2012 Global Report on Trafficking in Persons confirms that "there is little tangible evidence available that human trafficking within South Africa plays a large part in the sex trade" [6]. It states that

between 2010 and March 2011, South Africa's National Prosecuting Authority reported that 235 adults and 13 children were victims of human trafficking. Of those

\footnotetext{
${ }^{1}$ Her book on Selling Sex in Cape Town: Sex Work and Human Trafficking in a South African City can be read at: https://oldsite.issafrica.org/publications/books/selling-sex-in-cape-town-sex-work-and-humantrafficking-in-a-south-african-city. It examines the sex work industry in South Africa and the evidence for human trafficking in the industry.
} 
victims, 132 were trafficked for the purposes of sexual exploitation and 106 for use as forced labour. In 10 cases the purpose of the trafficking was listed as "unknown" [6].

During 2016 " 150 women were rescued from being sold into slavery in South Africa... in operations across the country in co-ordination with authorities from the US and neighbouring countries" [14]. Research done by Wilkinson and Chiumia (2013) estimates that the

\begin{abstract}
number of human trafficking victims reported... is exaggerated and sensational.... Such overestimations, while successful in capturing public attention and generating moral outrage, do not provide a sound basis for policy-making and resource allocation....

There is a need for real, reliable data to enable the implementation of government policies and the proper allocation of resources to combat genuine cases of human trafficking. NGOs that cry wolf to secure donor funding and newspapers that publish sensational reports without interrogating the figures hurt efforts to combat a real problem [6].
\end{abstract}

However, we cannot deny the fact that there is probably more trafficking taking place in South Africa than we are aware of. The reason for this is that there are no reliable enough or indeed enough research done on this issue. A very important finding in this respect by Motseki ${ }^{2}$ has to do with the modus operandi of perpetrators on human trafficking in three selected areas of the Gauteng province in South Africa. He indicates that these perpetrators have become "so organised that many victims are not even aware that they have been trafficked..." [15]. The participants, when asked about the modus operandi of these perpetrators, "explained that social media is mostly used by perpetrators to lure the victims. They emphasised that the perpetrators use the media to advise fake jobs, scholarships, modelling opportunities and employment opportunities" [15]. Motseki further notes that "it emerged that the majority of perpetrators were mostly Nigerians, Somalians, [and] Chinese followed by South Africans" [15].

To fight human trafficking, effective legislation and protective rights are needed.

\title{
3. Antihuman trafficking legislation in South Africa
}

South Africa was very slow to criminalise human trafficking. South Africa's former President, Jacob Zuma, "signed into law the country's first comprehensive legislation on human trafficking, the Prevention and Combating of Trafficking in Persons Bill (PCTPB), which, among other goals, seeks to implement South Africa's international obligations with respect to the problem" [16].

The legislation deals with a general definition of what constitutes trafficking. It includes

the delivery, recruitment, procurement, capture, removal, transportation, transfer, harbouring, sale, exchange, lease, disposal or receiving of a person or the adoption of a child facilitated or secured through legal or illegal means, within or across the borders of the Republic, of a person trafficked or of an immediate family member of the person trafficked, by ... [various] means [including threat of harm, fraud or abuse of power]... [16].

According to the Global Legal Monitor, the "legislation criminalizes various acts that constitute or relate to trafficking in persons and imposes harsh penalties for

\footnotetext{
${ }^{2}$ Read more about emerging themes and recommendations in his article [15].
} 
violations" [16]. It further refers to the fact that "legislation gives South African courts extra-territorial jurisdiction in certain circumstances" [16] including that "the suspect or victim is a South African citizen and present in South Africa; the suspect is a juridical person registered in South Africa [and] not extradited from South Africa..." [16]. This legislation also provides protection for victims of human trafficking, including persons coming from another country [16]. It provides that

\begin{abstract}
a victim of trafficking may not be charged for violating immigration law, for carrying forged documents or for other crimes that he/she was compelled to commit by his/her captors. It affords alien trafficking victims the same right of access to public healthcare services as that available to citizens. The legislation requires the Department of Home Affairs to grant alien victims of trafficking permission to remain in South Africa for a non-renewable 90-day term, as a recovery and reflection period [16].
\end{abstract}

In this regard it is also important to refer to certain instruments, rights and laws that protect children against sexual exploitation in South Africa. Compared to a number of sub-Saharan African countries,

\begin{abstract}
The South African government's political commitment to children is demonstrated in the entrenchment of children's rights in South Africa's Constitution and the country's ratification of a number of international and regional Child Rights instruments including the Convention on the Rights of the Child; the Optional Protocol on the Sale of Children, Child Prostitution and Child Pornography; and the African Charter on the Rights and Welfare of the Child. Domestic legislations such as The Children's Act 38 of 2005, the Sexual Offences Act 32 of 2007, Trafficking In Person (TIP) Act and the Child Justice Act provide a framework for the legal protection of children in South Africa [17].
\end{abstract}

In addressing this issue in a credible way, it is important to distinguish between human trafficking into sexual slavery and sex work. According to Ditmore "even those who mean well sometimes confuse the human rights abuse of trafficking in persons with the human occupation of prostitution, or sex work" [18]. She accentuates that the "trafficking of women and children into sexual slavery is undeniably a gross abuse of human rights. Like all trafficking, it involves coercion or trickery or both. Sex trafficking is an odious form of trafficking..." [18]. When a person on the other hand willingly takes part in the sale of sex and it is consensual, it is called sex work [19].

However, the difference between sexual slavery and sex work can almost be invisible. On the one hand you may not recognise the trafficked girl or woman, because she may look like someone who is looking for "work," but in reality she is not. On the other hand women's oppression, unemployment, lack of education, poverty and social and economic challenges (as in South Africa) may slide and force certain women into sex work, while the "outsider" may not be aware of this. In other words, it is not as voluntary as one may sometimes think [19].

The important question that should be asked is how should we think about sex work and the law if we distinguish it in principle from human trafficking and if we want to respect the dignity of sex workers?

\title{
4. Sex work, the law and its decriminalisation
}

There are approximately “ 182,000 sex workers who make a living selling sexual services in South Africa", and they "remain vulnerable to abuse and have no resource 
if they experience violence" [20]. ${ }^{3}$ Of these sex workers, specifically in South Africa, $90 \%$ are female and $10 \%$ are male or transgender [22, 23]. "All aspects of sex work are illegal in our country. The basis for the criminalisation of sex work has been seen as a social ill that needs to be eradicated". However, sex work despite prosecution and severe penalties continues. "Criminalising sex work has proved ineffective, maintaining high levels of violence, exploitation and abuse, and leads to the spread of illness" [21].

"An outdated criminal legal framework regarding sex work like ours in South Africa, can easily drive sex workers underground" and away from services [24], "increases stigma, discrimination and social exclusion, creates obstacles to accessing health and social programmes, and reduces sex workers' power, rendering them vulnerable to human rights violence and corruption" [21, 25].

There are however good reasons to decriminalise sex work in South Africa. Among others, "it reflects respect for human rights [26] and personal dignity... $[21,27]$; it reduces police abuse and violence" [21, 27, 28]; it promotes safer working conditions [21]; it increases access to health and social services [27]; and it reduces sex workers' risk of HIV and other STIs [27]. "Sex workers in South Africa are heavily affected by HIV and other sexually transmitted infections (STIs). HIV and STI prevalence among sex workers is higher than among other population groups. It is estimated that $60 \%$ of female sex workers in South Africa are infected with HIV [29]. An estimated $20 \%$ of the 350,000 people annually infected with HIV are connected with sex work. Approximately $6 \%$ of all new infections are estimated to occur among sex workers and $14 \%$ among sex worker clients or the sexual partners of the clients of sex workers [30]. In some settings, half to two thirds of sex workers have a curable STI at any time" [31, 32]. Decriminalising sex work further challenges stigma, discrimination and the consequences of having a criminal record [27]; it is argued that it does not result in an increase in the population of sex workers $[27,33,34]$; it facilitates effective responses to trafficking [27]; and it challenges state control over bodies and sexuality. Decriminalisation is an issue of gender equality, sexual rights and freedom ${ }^{4}$ and the right to bodily and psychological integrity [27].

"Where sex work is recognised as 'work,' workers experience the full protection of labour and occupational health laws, they have access to the necessary police services, could visit clinics without fear of harassment, and could work in any location" [21].

The first country in the world to decriminalise sex work was New Zealand in 2003. "In a review 5 years after the implementation of the new legislation sex workers reported that their working conditions and well-being had improved, they felt safer, and they were more likely to report abuse to the police" [21, 27, 36-38].

"Furthermore, researchers found that sex workers were generally practising safer sex, there was no increase in the number of sex workers in the industry, and many of the social evils predicted by some who opposed decriminalization have not occurred" [21]. There are many supporting bodies that assist women (and others) who are sexually exploited such as, among others, the Commission for Gender Equality in South Africa.

The current legal system criminalising sex work in its entirety is impractical and ineffective. The law needs to be reformed to make it consistent with South Africa's constitutional obligations from a human right perspective.

Gould reasons that

[c] hanging the Sexual Offences Act to decriminalise sex work would not of itself ensure that all sex workers are treated equally and fairly. However such a change would ensure that the basic rights of an employee are guaranteed by law and these rights could then be insisted upon [12].

\footnotetext{
3 This part of the chapter comes from an article written by the author [21].

${ }^{4}$ For more information on African women's sexual freedom, see Ref. [35].
} 
Changing the law would be a huge symbolic act of inclusion, although it is understood that stigmatisation of sex workers will not change overnight. If this happens it will make South Africa the first African country to decriminalise sex work.

This now brings us to one of South Africa's most iconic and mythologised sex slaves of all times. Many women trapped in sex slavery would probably strongly relate with her experience regarding gender inequality, sexual exploitation and abuse, humiliation and indignity.

\section{The Saartjie Baartman story}

Our South African history is characterised by sexual slavery and exploitation. A prominent story formerly unknown for many South Africans came to light in 1994 after former President Nelson Mandela requested that the remains of Saartjie Baartman be returned to South Africa.

In short her story goes as follows: at the beginning of the nineteenth century, this Khoikhoi woman, a mere 20-year-old, was taken from the Cape to England and Ireland by William Dunlop and Hendrik Cezar to work as a "domestic servant, and be exhibited for entertainment purposes" [39]. She was exhibited almost completely naked in a cage in various circuses under the artistic name Hottentot Venus, although she never wanted to pose naked [40]. But "she became an attraction for people from various parts of Europe" [39]. In France she was exhibited in a "cage alongside a baby rhinoceros" [39]. Baartman was especially popular with the general public because of her physique. She was exploited for most of her life, as well as humiliated, and after her death, a plaster cast was made of her body, and her brain and genitals were pickled in jars and placed on display until 1974. Baartman was used "to help emphasize the stereotype that Africans were oversexed and a lesser race" [39]. Following the African National Congress's victory in the 1994 elections

President Nelson Mandela requested that the French government return the remains of Sara Baartman so that she could be laid to rest. Finally on the 9 March 2002, Sara Baartman was brought back home to South Africa where she was buried. On 9 August 2002, Women's Day, a public holiday in South Africa, Sara was buried at Hankey in the Eastern Cape Province [39].

\subsection{What do we learn from the Sara Baartman story?}

According to Crais and Scully in their well-documented book Sara Baartman and the Hottentot Venus: A Ghost Story and a Biography, Sara was always seen as a symbol and never as a human being. "In the Museé de l'Homme a simple plaque read by millions memorialised an illusion, a spectral being, someone who never existed except in the minds of others" [41].

Sara Baartman has well into the twentieth century shaped French culture, particularly with regard to female sexuality. "Writers on prostitution consistently tied it to the savage woman, the 'terrible voluptuousness' of the 'wild Venus,' according to a 1930 play" [41]. Sara was especially known for her bottom, according to Simenon as quoted by Crais and Scully, "the most famous bottom in the world. It must be the only bottom which has become the centre of a cult. And it is everywhere" [41-43].

Sara Baartman has been reduced to men's image, not only of her body but of her genitals and "the ways the organs of sexual pleasure stood for character, her very being. White women, even the most civilised, were liable to fall victim to their animal instincts and passions, to revert to their Hottentot selves" [41]. This led 
to European prostitutes becoming degenerate women, "literally women who had become more Hottentot" [41].

People were fascinated by these women's genitals, even their rough faces [41]. In light of this, laws throughout Europe have been devised by politicians and bureaucrats to

control the biological deviance of prostitutes and female sexuality. In Europe and in the United States, doctors cut or burned women's clitorises off with acid. Surgeons destroyed women's genitals to make them less pronounced, less like the Hottentot Venus to control their sexual cravings and brute drives of these "unmanageable" women. In some cases, doctors argued, castration was warranted; in the United States the practice continued through the 1950s [41, 44, 45].

Even today, just in Africa, approximately 2 million cases of genital mutilation are performed on women every year 5 [46, 47].

Sara Baartman's story became the story, actually the story of what menespecially white men-do to women, especially innocent black women. In this sense it's firmly part of global feminism.

What happened to Baartman happened to women all the time, the world over. Men perpetrated violence on women's bodies, dispossessed their bodies through violent appropriations and worked out their fantasies through stories, songs and scalpels. For good reason Sara Baartman's story became a history of human rights and their all-too-frequent violation, the body as a narrative of the ignominies of science, an eighteenth century and early nineteenth-century woman a testament to the great and enduring disgraces of Western civilisation.... In life, death and now in her resurrection as a person, Baartman remained desire's cypher [41].

Sara Baartman was repatriated not to her family, but to a nation. According to a final report of the Department of Arts and Culture, "[i]t was victory over colonialism, racism and sexism. It very visibly and publically restored the dignity of a South African woman exploited and humiliated in her lifetime" [41]. In laying to rest Sara's remains, many women flew from all over the world to attend the ceremony. Although she has become a national symbol, icon and a symbol for women all over, the ceremonies largely entailed men "speaking on behalf of women and their rights as South African citizens" [41]. Laying her to rest on National Women's Day reminded South Africans and the world of the long history of women's oppression. At her funeral, Thabo Mbeki, then State President of South Africa, spoke of "the persistence of gender violence and of the necessity of gender equality to realising a truly democratic South Africa" [41]. The restoration of the dignity of Sara Baartman implied the restoration of the dignity of black South Africans, especially of the Khoisan.

Sadly her grave was vandalised, and today it is surrounded by tall green metal bars. The important question to be asked: although Sara Baartman returned to South Africa, is not she still behind bars, imprisoned-like so many other sexually exploited and trafficked women? [41].

\section{Gender}

Sara Baartman, this famous South African woman, confronts the historical past of South Africa with current gender inequality, exploitation, violence, humiliation and indignity. ${ }^{6}$ There might be many women today who could identify with

\footnotetext{
${ }^{5}$ For information see [46].

${ }^{6}$ For more information about the power dynamics in sex work, see Gould [48].
} 
what happened to her, and (re)telling her story will hopefully connect her not only with her descendants but also with other women who are trapped in some form of sex slavery, especially those who are forced to work between and among different cultures to earn an income [41].

Some of the important drivers of human trafficking and sexual slavery are poverty, oppression and a lack of equal human rights for women, like we have seen in the case of Sara Baartman. "Worldwide prevention has to begin at these points" [47]. According to Schirrmacher, "women are frequently affected by unemployment, low wages, violence, and economic hardship. Through the general lack of prospects, women are drawn into situations where they can be exploited by human traffickers" [47].

In a place like South Africa, with so many young people and huge gap between the rich and the poor, it really becomes a battle with poverty, patriarchy and economic justice. "If we do not deal with some of the push factors, such as gross poverty, vulnerable women and children will continue to be exploited by outsiders and their own alike" [49].

In this regard, without discussing it in detail, it will increasingly be important for South Africans to deal with gender as a cultural concept. We are not born with gender roles and they are not biologically determined. Rakoczy reasons that as cultural beings, discrimination is in the first place played out in our bodies which usually results in the objectification of women [50].

Men can easily "assert power over women by using violence" which could make women "silent and submissive" [49]. As South Africa constantly pushes for gender equality, there is still in many respects inequality that has to be addressed and transformed. South Africa's Gender Inequality Index score (2017) is 0.389 which places our country at 90 out of 143 countries [51]. According to O'Connor, "gender equality and empowering women in South Africa must not be seen just to promote economic and social development and sustainable peace and security but as a human rights issue" [49]. She further states that this "necessitates that women's issues are kept on the public agenda and that both men and women work together at meaningful transformation of conditions that govern the lives of both" [49].

South Africa will also have to deal with traditional practices that lend themselves to the trafficking of women and girls. In light of the South African Constitution that protects women's rights to equality and prohibits any form of discrimination, certain traditional practices will have to be addressed which include myths, forced marriages, female genital mutilation or cutting, virginity testing and priority in educating boys, to name a few. Although the Children's Act of 2005 safeguards the rights of children and "traditional institutions are subject to the principles of the constitution and promulgated laws... civil law is at times ineffective in replacing the prevailing customary law, particularly in rural areas" [1]. This causes such practices to continue especially to oppress females. If we are serious, in South Africa as well as globally, to address gender inequality effectively in order to combat sex slavery, we need to challenge the abovementioned practices but also the gender inequalities which we so often find in so many South African faith-based contexts [49].

Some of the key elements to enhance gender equality and address sexual slavery is education-to convey critical important information, honest law enforcement, political will, responsible government action in trying to create the best and most viable solution to sexual slavery and economic support for all the role players involved in addressing this important issue and in rehabilitating survivors of sexual slavery.

In addressing these elements, government, communities and organisations follow the prevention, protection and prosecution approach. This includes more specifically capacity building workshops, counter-trafficking committees, networking between concerned role players, awareness campaigns, challenging unethical 
traditional practices and a national hotline, to name a few. The South African government, through a multidimensional programme, further promote "gender equality in all spheres of life... [and] basic human rights..." which includes "the right to the necessities of survival and development". This programme "is set out in various laws" and in the "National Policy Framework for Women's Empowerment and Gender Equality” [1].

Motseki argues that a "focus on vulnerability will enhance the human rights component of trafficking prevention policies" and that an "improved cohesion between relevant role-players, would go a long way to align day-to-day tactics into... long term anti-trafficking strategies and national responses" [15]. He further pleads for a "multi-disciplinary unit within the Directorate for Priority Crime Investigation" which includes officials from different relevant departments, services and authorities [15].

However, Bello ${ }^{7}$ argues in this respect that as currently structured, "the South African criminal justice system cannot effect long-term combating strategies against human trafficking" [53]. He refers to findings that "indicate that the solution to the precipitating factors that fuel the trade in human commodity lies outside the scope and mandate of the criminal justice system" [53]. For an effective response, he continues, "it is expedient for the State to first address the socio-economic, cultural and political nuances that fuel the trade, rather than mount impracticable pressure on its criminal justice institutions to perform an unrealistic task" [53]. Unfortunately, according to him, "since the enactment of the anti-trafficking law in 2013, and its implementation in 2015, the South African criminal justice system have not really made headway in the fight against this heinous crime" [53].

However, gender justice presupposes equality of outcome and opportunity which has clear consequences for sex slavery, sex work and exploitation. South Africa's Constitution reflects sighs from around the world to promote gender justice. The South African Human Rights Commission has been awarded to support constitutional democracy through promoting, protecting and monitoring the attainment of everyone's human rights, including women and children, in South Africa without fear, favour or prejudice.

The Sustainable Development Goals of the United Nations has as one of its objectives "a world in which every woman and girl enjoys full gender equality" [4]. South Africa is a signatory to this quest. To further augment this journey South African politics has elevated gender justice to the highest echelons of decision-making by establishing a Department of Women in the Presidency tasked to "champion the advancement of women's socio-economic empowerment and the promotion of gender equality" [54].

\section{Conclusion}

In order to achieve an ongoing analysis of the extent of the problem of sex slavery and exploitation in South Africa, we need much more reliable data and well-researched literature to establish a platform for reform and progress. ${ }^{8}$ Antitrafficking legislation in South Africa "requires annual reports to Parliament on the implementation of the Act and the number of cases of human trafficking" [6]. If done properly on an ongoing basis, it must consequently result in more reliable data and research by (academic) scholars in order to learn more about the prevalence and nature of trafficking in South Africa—to fill the knowledgeable gap. This can

\footnotetext{
7 In this regard also read [52].

${ }^{8}$ For general recommendations for action by the state regarding the exploitation of sex work, see [55].
} 
unfortunately create a situation in which "policies may be made and resources be allocated on the basis of what may not be an accurate reflection of the reality of the problem" [5]. Opposed to this, there is a need for reliable data on the extent of sex slavery, the profile and motivations of victims and traffickers, how many South Africans are trafficked to other countries, the nature of the exploitation, the environment in which it occurs, activities to prevent sex slavery and what kind of support infrastructure is available to victims, to name a few [5]. According to Geldenhuys [56] "there should [also] be intensified training of police officials and other role players in identification and policing of trafficking" [57].

It is crucially important that South Africa will learn from international literature, reports and studies on sex slavery, exploitation and gender justice. This will help us to adopt a more sophisticated approach in this regard, although it must be stated that there are (methodological) weaknesses in some of the international literature and studies on sex slavery and exploitation. Discernment is needed in order to study this and other literature critically for a better analysis regarding the extent of sex slavery and exploitation in South Africa [5].

With regard to the way forward, it must be acknowledged that it is very difficult to access sex slavery victims and/or to infiltrate trafficking networks to gather more comprehensive data. Thorough unemotional research is however needed to further ground and stimulate this debate with credibility in South Africa.

\section{Author details}

Chris Jones

Faculty of Theology, Stellenbosch University, Stellenbosch, South Africa

*Address all correspondence to: chrisjones@sun.ac.za

IntechOpen

(C) 2019 The Author(s). Licensee IntechOpen. This chapter is distributed under the terms of the Creative Commons Attribution License (http://creativecommons.org/licenses/ by/3.0), which permits unrestricted use, distribution, and reproduction in any medium, provided the original work is properly cited. (cc) BY 


\section{References}

[1] Tlhagale B. In: O’Connor M, editor. The Church and Human Trafficking. Dorpspruit: Cluster Publications; 2013. pp. ix, x; 90-95; 100-101

[2] Kristof N, Wudunn S. Half the Sky. London: Virago Press; 2010. p. 12

[3] Available from: https://www.unodc. org/documents/data-and-analysis/ glotip/2016_Global_Report_on_ Trafficking_in_Persons.pdf [Accessed: 28 December 2018]

[4] Available from: https:// sustainabledevelopment.un.org/sdgs [Accessed: 28 December 2018]

[5] Pharoah R. Getting to Grips with Trafficking. Reflections on Human Trafficking Research in South Africa. Brooklyn, Pretoria: Institute for Security Studies; 2006. pp. 48-49; 76-78

[6] Available from: https://africacheck. org/reports/are-30000-kids-traffickedinto-south-africas-sex-trade-everyyear-the-claim-exaggerates-theproblem/ [Accessed: 4 October 2018]

[7] Available from: https://www.iol. co.za/news/45-000-kids-prostitutedin-sa-1521439/ [Accessed: 9 October 2018]

[8] Available from: https://www.iol. co.za/news/south-africa/traffickingof-people-the-cup-crisis-that-neverwas-490109/ [Accessed: 11 October 2018]

[9] Available from: http://www.sweat. org.za/wp-content/uploads/2016/02/ Position-Paper-on-Sex-Work-inSouth-Africa-2015-1.pdf/ [Accessed: 19 October 2018]

[10] Available from: https://www.iol. co.za/news/south-africa/traffickingof-people-the-cup-crisis-that-neverwas-490109/ [Accessed: 19 October 2018]
[11] Kelly L. You can find anything you want: A critical reflection on research on trafficking. In: Data and Research on Human Trafficking: A Global Survey. Geneva: International Organisation for Migration (IOM); 2005. p. 239

[12] Gould C. Selling Sex in Cape Town: Sex Work and Human Trafficking in a South African City. Institute for Security Studies (ISS); 2008. pp. 104, 105, 150-151. Available from: https:// oldsite.issafrica.org/publications/books/ selling-sex-in-cape-town-sex-workand-human-trafficking-in-a-southafrican-city/. [Accessed: 4 November 2018]

[13] Available from: http://www. ngopulse.org/resource/selling-sex-capetown [Accessed: 16 January 2019]

[14] Available from: https://www.iol. co.za/news/human-trafficking-a-crimehidden-in-plain-sight-2055073

[15] Motseki M. An evaluation of perpetrators modus operandi on human trafficking in three selected areas of Gauteng province, South Africa. In: International Journal of Social Sciences and Humanity Studies. 2018;10(1): 180, 184, 186

[16] Goitom. 2013. Available from: http://www.loc.gov/law/foreign-news/ article/south-africa-anti-humantrafficking-legislation-signed-into-law/, n.p., [Accessed: 8 November 2018]

[17] Available from: http:// childwelfaresa.org.za/sexualexploitation-and-trafficking/ [Accessed: 12 November 2018]

[18] Ditmore. 2008. Available from: https://www.alternet.org/story/84987/ sex_work_vs._trafficking\%3A_ understanding_the_difference/ n.p., [Accessed: 24 October 2018] 
[19] Available from: https://www. stopthetraffik.org/sex-trafficking-vssex-work-understanding-difference/ [Accessed: 18 January 2019]

[20] Available from: http://www. sweat.org.za/sexworkiswork/\#, p.2, [Accessed: 26 October 2018]

[21] Jones C. Criminalising sex work wholly unconstitutional. Cape Argus; 16 March 2018 [Accessed: 24 October 2018]

[22] Konstant TL, Rangasami J, Stacey MJ, Stewart ML, Nogoduka C. Estimating the number of sex workers in South Africa: Rapid population size estimation. AIDS Behav. 2015;19(Suppl 1):S3-S15

[23] Richter M, Chersich MF, Temmerman M, Luchters S. Characteristics, sexual behaviour and risk factors of female, male and transgender sex workers in South Africa. South African Medical Journal. 2013;103(4):246-251

[24] Gable et al. HIV/AIDS, reproductive and sexual health, and the law.

American Journal of Public Health. 2008

[25] Scorgie F et al. Socio-demographic characteristics and behavioural risk factors of female sex workers in subSaharan Africa: A systematic review. AIDS and Behaviour. 2012;16:920-933

[26] International Committee on the Rights of Sex Workers in Europe. Declaration of the Rights of Sex Workers in Europe. 2005. Available at http://www.sexworkeurope. org/en/resources-mainmenu-189/ declarationmainmenu-199

[27] Available from: https://www. opensocietyfoundations.org/sites/ default/files/decriminalize-sexwork-20120713.pdf/, pp. 2-5, [Accessed: 25 October 2018]
[28] Gould C. Selling Sex in Cape Town: Sex Work and Human Trafficking in a South African City. Woodstock: ISS; 2008. pp. 55-61

[29] Baral S, Beyrer C, Muessig K, Poteat T, Wirtz AL, Decker MR, et al. Burden of HIV among female sex workers in low-income and middle-income countries: A systematic review and meta-analysis. The Lancet Infectious Diseases. 2012;3099, 12:1-12. DOI: 10.1016/S1473-3099(12)70066-X

[30] SACEMA. The Modes of Transmission of HIV in South Africa. Report; 2009

[31] Dunkle KL, Beksinska ME, Rees HV, Ballard R, Htun Y, Wilson M. Risk factors for HIV infection among sex workers in Johannesburg, South Africa. International Journal of STD and AIDS. 2005;16:256-261

[32] Available from: http://www.sweat. org.za/wp-content/uploads/2016/02/ National-Sex-Worker-Strategy-plan-forHIV-Prevention-1.pdf/, p.4, [Accessed: 24 October 2018]

[33] Harcourt C, Egger S, Donovan B. Sex work and the law. Sexual Health. 2005;2:121-128

[34] Abel G, Fitzgerald L, Brunton C. The impact of decriminalisation on the number of sex workers in New Zealand. Journal of Social Policy. 2009;38(3):515-531

[35] du Toit L. Human rights discourse: Friend or foe of African women's sexual freedoms? Acta Academia. 2014;46(4):49-70

[36] Slamah K, Winter S, Ordek K. Stigma and violence against transgender sex workers. RH Reality Check. 16 Dec. 2010. Available from: http://www. rhrealitycheck.org/blog/2010/12/16/ stigma-exclusion-violence-againsttransworkers 
[37] New Zealand Ministry of Justice. Report of the Prostitution Law Review Committee on the Operation of the Prostitution Reform Act. 2003. Available from: http://www.justice.govt. $\mathrm{nz} /$ policy/commercial-property-andregulatory/prostitution/prostitutionlaw-reviewcommittee/publications/ plrc-report/documents/report.pdf

[38] Commission for Gender Equality. Decriminalising sex work in South Africa; 2013

[39] Available from: https://www. sahistory.org.za/people/sara-saartjiebaartman/ [Accessed: 21 October 2018]

[40] Available from: https://www.litnet. co.za/sarah-baartman-hoekom-sy-hoekomhaar-graf/ [Accessed: 17 January 2019]

[41] Crais C, Scully P. Sarah Baartman and the Hottentot Venus. A Ghost Story and a Biography. Johannesburg: Wits University Press; 2009 pp. 142, 146, 147, 158, 160-162, 164, 166, 168

[42] Stuart A. Showgirls. London: J. Cape; 1996

[43] Gale M, Stokes J. The Cambridge Companion to the Actress. Cambridge: Cambridge University Press; 2007

[44] Gilman S. Difference and Pathology: Stereotypes of Sexuality, Race and Madness. Ithaca, N.Y.: Cornell University Press; 1985

[45] Showalter E. The Female Malady. New York: Pantheon Books; 1985

[46] Dora TT. The Role of the Church in Ending Female Genital Mutilation/ Cutting in order to Promote the Flourishing of Women: A Case Study of the Wolaita Kale Heywet Church, Southern Ethiopia. M.T. Stellenbosch: University of Stellenbosch; 2018

[47] Schirrmacher T. Human Trafficking. The Return to Slavery. Bonn: VKW; 2013 p. 34,53
[48] Gould C. Selling Sex in Cape Town: Sex Work and Human Trafficking in a South African City. Woodstock: ISS; 2008. pp. 156-158

[49] O'Connor M. The Church and Human Trafficking. Dorpspruit: Cluster Publications; 2013. pp. 55, 58-67, 102

[50] Rakoczy S. In Her Name: Women Doing Theology. Pietermaritzburg: Cluster Publications; 2004. pp. 280-284

[51] Available from: http://hdr.undp. org/en/composite/GII/ [Accessed: 15 November 2018]

[52] Bello PO, Olutola AA. The enforcement of anti-human trafficking law in South Africa: A case of an aircraft without a pilot. Police Practice and Research. 2018;19(3)

[53] Bello PO. Long-term criminal justice response to human trafficking in South Africa: An impossible mission. Contemporary Justice Review, Issues in Criminal, Social, and Restorative Justice. 2018;21:475-476

[54] Available from: http://www.women. gov.za/ [Accessed: 19 December 2018]

[55] Gould C. Selling Sex in Cape Town: Sex Work and Human Trafficking in a South African City. Woodstock: ISS; 2008. pp. $161-168$

[56] Geldenhuys ICH. A Critical Understanding of the Policing of Trafficking in Persons. Pretoria: University of South Africa; 2017. Available from: http://hdl.handle. net $/ 10500 / 23126$

[57] Available from: https://www. timeslive.co.za/news/south-africa/201805-30-human-trafficking-is-silentlytearing-south-africa-apart-experts-say/ 


\title{
Chapter 2
}

\section{The Conundrum of Human Trafficking in Africa}

\author{
Paul O. Bello and Adewale A. Olutola
}

\begin{abstract}
This chapter explores the nature, extent and mystification of human trafficking in Africa. While human trafficking is an age-long, border-less crime of global proportion, its current form and dimensions have enormous negativity on the human race (generally), and pose enormous threats to peace and security on the African continent (specifically). Such consternation has engendered various stakeholders to introduce policy measures to curb the spread; however, rather than diminishing, it is ever increasing. From a positional standpoint, using document analysis, this chapter provides a synopsis of human trafficking in Africa, in recent times, and offers suggestions on pragmatic steps that could help address both the demand and supply end of this illicit criminal enterprise in twenty-first (21st) century Africa.
\end{abstract}

Keywords: human trafficking, crime, globalisation, Africa

\section{Introduction}

Human trafficking is a global issue that affects people from virtually every part of the world. Though statistics on the extent of the crime is hard to prove, anecdotal reports suggest that it is increasing [1]. For instance, more than 500 different trafficking flows were detected between 2012 and 2014 across the globe [1]. Similarly, from a recent global survey on human trafficking published by International Labour Organization (ILO) and the Walk Free Foundation, an estimated 40.3 million people were reported to be in modern slavery in 2017 [2]. While the total annual revenue accruing from human trafficking varies, depending on the source, but it is estimated to be between US\$ 5 and US\$42 billion [3].

Although human trafficking is common in different continents of the world, it is endemic in Africa. Africa has been bedevilled with a number of crisis, including high levels of unemployment, poverty, hunger, corruption, political and economic instabilities, to mention a few $[4,5]$. These problems are exacerbated by tensions and insurrections, which have led to internal displacements of people. The quest for survival in the midst of these socio-political and economic crises have engendered high migration flow from one African State to another; from one African region to another, and from Africa to other continents. While some migration activities are legal, many others are carried out illegally. Meanwhile criminals regularly deceive migrants and traffick them into a world of different dimensions of exploitation. While the exact numbers and demographics of trafficked persons from Africa are unknown, the United Nations Office on Drugs and Crime (UNODC) reports often provide guestimates of the realities [6]. For instance, according to UNODC report 
in 2016, a total of 69 countries detected human trafficking victims from SubSaharan Africa between 2012 and 2014 [1].

The scale of human trafficking in Africa came from alarm raised by activists, civil societies and Non-Governmental Organisations (NGOs), especially in Nigeria, Togo, South Africa, Benin Republic, to mention a few in the latter 1990s [7-10]. For instance, anecdotal reports indicated that human trafficking in West Africa has assumed alarming proportion since the mid-1990s $[8,11,12]$. Child trafficking also became prominent in West Africa when international media focused on the exposure of a ship code-named Etireno which was found on 17 April 2001 with children between the ages of 3 and 13 who were trafficked to Libreville, Gabon, from Lagos in Nigeria [11]. While there have been considerable efforts at international, national and regional levels at combating human trafficking in Africa, unfortunately, limited successes have been recorded $[11,13]$.

The purpose of this chapter is to discuss the nature, extent and the complexities of human trafficking in Africa. It draws from a review of literature on human trafficking in different parts of Africa and beyond. The chapter begins with the conceptualisation of human trafficking, and moves onto an overview of human trafficking in Africa; the factors engendering human trafficking in Africa, and suggestions for effective response to it.

\section{Human trafficking: conceptual clarifications}

Defining human trafficking is relatively contentious $[2,11,14,15]$. Part of the controversy revolves around the array of activities that are involved in it. This could be part of the reasons why Gould [16] described it as 'a slipping concept' that is very difficult to pin down. Moreover, the controversy between traditional practices and modernisation sometimes blur the understanding and definition of the concept. Portrayals of human trafficking in Western democracies may be different from that of Africa [6]. For instance, a child hawking goods in public could be construed as a form of exploitation, but in some Western African societies, it could be part of the routines of a child in order to assist his/her parents [11].

The definition of human trafficking varies from scholar to scholar, and country to country. Most of the debates are rooted in divergent worldview, historical backgrounds and findings from studies conducted by scholars [17]. Trafficking in persons (human trafficking) is defined in article 2(a) of the 2000 Protocol to Prevent, Suppress and Punish Trafficking in Persons, Especially Women and Children (Palermo Protocol), supplementing the United Nations Convention against Transnational Organized Crime, as:

The recruitment, transportation, transfer, harbouring or receipt of persons, by means of the threat or use of force or other forms of coercion, of abduction, of fraud, of deception, of the abuse of power or of a position of vulnerability or of the giving or receiving of payments or benefits to achieve the consent of a person having control over another person, for the purpose of exploitation.

Exploitation includes, at a minimum, the exploitation of the prostitution of others or other forms of sexual exploitation, forced labour or services, slavery or practices similar to slavery, servitude or the removal of organs. The consent of a victim of trafficking in persons to the intended exploitation... shall be irrelevant where any of the... [fore-mentioned] means...have been used. The recruitment, transfer, harbouring or receipt of a child for the purpose of exploitation shall be considered 'trafficking in persons', even if it does not involve ... [any of the above listed means]. 
'Child' shall mean any person under eighteen years of age (Article 3) (UNODC, 2004, p. 42).

For the purpose of this article, human trafficking is defined as the deception, recruitment, transportation and transfer of persons, for the purpose of exploitation.

\section{Human trafficking: an overview of human trafficking in Africa}

The end of the Cold War resulted in the rise of regional conflicts in Africa and the decline of borders, leading to an increased number of economic and political refugees $[18,19]$. Since then, the rates of human trafficking in different parts of Africa have also increased considerably due to capacity gaps in the management of sub-regional economic cooperation and regional integration initiatives among African states [18]. This situation led to several interventions by policy makers and other stakeholders at the continental, regional and national levels. However, many African countries are still finding it very challenging to combat human trafficking due to ineffective policies and capacity, even where legislation is in place. The combination(s) of lack of political will, political and institutional corruption, and a range of other underlying perennial socio-economic problems that these countries are confronted with have made the fight against human trafficking almost insurmountable $[7,18]$.

Human trafficking is a dynamic phenomenon with a range of interlocking forces, factors and processes [6]. Trafficking issues and challenges often revolve around three variables, (though with two extreme ends) - the demand for cheap labour and exploitation on one hand, and the willingness to meet basic economic needs for survival on the other ([20], p. 7). It will be erroneous to describe human trafficking essentially as an economic cum security issue, perhaps due to the factors that entrap people into it.

Trafficking features in West Africa is complex, so are its routes. Countries like Nigeria, Ghana, Cameroon and Senegal are source, transit, and destination countries for trafficked women and children [1]. Trafficking of young girls from rural areas in countries such as Mali, Benin, Burkina Faso, Togo, and Ghana to work in Cocoa plantations in Urban Cote D'Ivoire are also documented in literature [1]. Trafficking from and through eastern Nigeria to Gabon have increased in recent years [1]. According to United Nations International Children's Emergency Fund (UNICEF) 2017 report, children made up over a quarter of detected trafficking victims in the world, and out of this, 64\% are from sub-Saharan Africa. This figure would have increased in recent times due to current political and economic challenges in sub-Saharan Africa that have compelled several people, including women and children to leave their homes in search of new opportunities in neighbouring countries [21-29].

Similar to the experience in West Africa, human trafficking is prevalent in Southern Africa. Countries such as South Africa, Mozambique, Zambia, and Lesotho are source, transit and destination countries for human trafficking [9]. However, unlike the West African scenario where the flow is multidimensionalone country could serve as the source, while another serve as the transit and destination point-trafficking geography in Southern Africa is relatively complicated. It involves complex trafficking flows from diverse countries of origin from Africa and the rest of the world [10]. In this region, South Africa serves as the rallying point. In addition to its status as the powerhouse of the sub-region, South Africa also serves as an economic hub on the African continent. Until recently, has the largest 
economy in Africa [30], South Africa also serves as a major hub for trade in human commodity $[6,31]$. It provides an enabling environment and market for the services of trafficked persons from the regional and extra-regional level [32]. Incessant crises that ravaged the Continent, such as political instabilities, insurrections, poverty, hunger, unemployment, kidnapping, terrorism, amongst others, make South Africa a magnet that attracts migration flows from other African countries [6, 33].

It is imperative to state that in the Southern African axis, South Africa serves mainly as the destination point. This is not to infer that South Africa is not a source or transit country for human trafficking, but as the economic hub of the region, South Africa is the main destination points for Southern African sub regional and extra-regional flows. Within South Africa, women and children are recruited and transported from the rural areas to cities, such as Johannesburg, Pretoria, Bloemfontein, Cape Town and Durban, for exploitation [6]. While most girls work as domestic servants in wealthy homes, majority of the boys serve as street vendors, waiters, beggars on the roads, street urchins, labourers on farm lands and plantations, and for other criminal activities [6].

According to United States Department of State Trafficking in Persons Report [34], West African syndicates dominate and control the commercial sex business in Hillbrow (Johannesburg) and other urban centres across the State, local criminal rings control child prostitution in the country. While Russian and Bulgarian crime syndicates control prostitution business in the Cape Town axis, the Chinese nationals organise and coordinate the sex trafficking of Asian nationals [34].

Children are trafficked to South Africa from Lesotho's border towns; women and girls trafficked from Mozambique are destined for South Africa's Gauteng and Kwa-Zulu Natal provinces [10]. In Malawi, women and girls are trafficked to northern Europe and South Africa. In addition to these configurations, women are also trafficked from Thailand, China, and Eastern Europe [35]. Ethnically based criminal syndicates in South Africa's refugee camps recruit and transport their victims, usually married women from their home countries.

In Lesotho, traffickers often recruit male and female street children, victims of physical and sexual abuse at home, or children orphaned by AIDS [7]. Such children normally migrate from rural areas and border towns to Maseru, the capital, from where they are trafficked by mostly South African white Afrikaans to work in farms in Eastern Cape. In Mozambique, men, women and children are trafficked from Maputo to Durban or Johannesburg for various exploitative purposes. While women and children are trafficked to provide sexual services to miners at West Rand, men are trafficked for labour related task at the mines [7, 35].

In East African axis, Ugandan and Kenyan women are trafficked for prostitution in the Gulf States. The incessant crises in Uganda created an avenue for rebel leaders to kidnap children, young girls and women from the opposition camps [34]. In addition to the locals, victims of trafficking in Uganda are from the Democratic of Congo (Congo DRC), Burundi, Kenya, Tanzania, Rwanda and South Sudan [34]. While girls, young ladies and women are forced into prostitution, boys and men work in agricultural, construction and other labour related industries in Uganda [34] Similarly, Kenya serves as a source, transit and destination country for trafficking of young girls and women to and from Europe [34].

Human trafficking also thrives in North Africa. Virtually all countries in this region of Africa are source, transit and destination countries for trade in human commodity [7]. However, there may be variations in the volume of trafficked victims are transported from and into each of the countries in the region [7]. For instance, Algeria is more of a transit and destination country than a source country, unlike other countries in the region like Egypt, Morocco and Tunisia that are essentially a source, transit and destination countries for human trafficking [34]. 
Traffickers in this region of Africa target undocumented (illegal) migrants from sub-Saharan Africa, like Mali, Niger, Cameroon and Nigeria. The illegal status of such migrants and language barriers make them vulnerable to various forms of exploitation by traffickers who often deceive them with a view to make them fill the available vacancies in the labour and sexual trafficking industries [6]. Contrastively, illegal migrants often fall prey to traffickers in North Africa while trying to cross the borders of some of the countries in the region en route Europe with the perception of improving their lives. While Europe is their ultimate destination, travelling long distances through the desert, especially Sahara desert en route Europe make them vulnerable to exploitation. Due to the long distances they are to cover, and the cost of transportation, these illegal migrants often run out of money, seek avenues to survive. Traffickers, aware of their vulnerabilities subject them to labour and sexual exploitation (USTIP Report, 2016). In addition, in Egypt (precisely), women and children are vulnerable to labour and sexual exploitation (USTIP Report, 2016). Men from United Arab Emirates (UAE), Kuwait and Saudi Arabia often purchase summer (temporary) marriages for commercial sexual exploitations. There are documentations of child sex tourism in Cairo, Luxor and Alexandria in Egypt (USTIP Report, 2016).

Studies have indicated an increase in migration flows across the world. Most of these flows are largely attributed to myriad of factors ranging from political upheaval, to economic-crises, ethnic discrimination, communal inequalities, civil wars to lack of viable means of livelihood ([7], p. 83; [36], p. 11; [37], p. 7). For people ensnared by hunger and poverty, migration through what Maggy Lee described as 'irregular channels of smuggling and trafficking' become an alternative means of survival or an escape route ([37], p. 7).

\section{The nexus between human trafficking in Africa and globalisation}

In Africa, human trafficking is of two dimensions - internal and external trafficking $[1,19]$. Although there have been debates on the validity of this assertion, studies on human trafficking have shown that a country could serve as origin (source), transit and destination for trafficking operations [19]. For instance, citizens of countries as Canada, United Kingdom and New Zealand may find it difficult to accept that human trafficking thrives in their countries due to their tight border and sophisticated immigration control, however, studies have shown that virtually all country of the world is implicated in human trafficking web [19].

The market for this criminal trade is wide, owing to the lucrative nature of this business. The markets are often driven by highly sophisticated criminal gangs with network that span across States frontiers. The expansion of global market for trade and investment necessitated an increase in the demand and supply of people ([36], p. 26). Such expansion often culminates in high migration flow, and hibernating in the exodus of these individuals is this illicit trade (human trafficking). Similarly, globalisation created demographic disparities among the less-developed, developing and the developed countries, resulting in what Shelley referred to as 'the feminization of poverty' and 'marginalisation of rural communities' ([19], p. 3).

Globalisation has been enhanced considerably by the internet and the so called 'dark web' $[1,2]$. Such platforms have often been exploited by traffickers to advertise and lure people into the trafficking world $[2,19]$. Through the internet, several girls and ladies have been lured by traffickers (under the pretext of providing immigration services) to unknown destinations, where they are raped, and exploited [1]. Child pornography, online sex chats and other forms of illicit services, have been rendered by traffickers to different clients across the globe ([36], p. 130). Human 
trafficking has also been linked with sporting events ([36], p. 141). However, there are arguments and counter-arguments about its actual estimate.

The wave of natural disasters that swept through several countries of the world due to global warming has left many people homeless, displaced and impoverished. Examples of these natural disasters include the tsunami that swept through the Southeast Asian countries, the hurricane Katrina in New Orleans, drought in Sudan, and earthquake in Haiti [36]. Unfortunately, humanitarian responses to most of these emergency situations have often been undermined by corruption [1, 15]. According to Shelley [19] most of the assistance programmes and initiatives to assist disaster victims have largely been inadequate, with most of the needed aid too often, have been diverted by corrupt officials. The combination of the loss of their lands-both commercial lands and residential lands, and the uncertainty of securing any opportunity in other sector of their national economy, these distressed people often become vulnerable, and easy prey for traffickers ([19], p. 38).

\section{Forms of human trafficking in Africa and the criminals (forces) involved}

In Africa, trafficking in Persons is of two different types. Literatures on the phenomenon suggest the internal and external trafficking $[38,39]$. Internal trafficking takes place within a country's territory (domestic trafficking). It usually takes the form of recruitment and movement of people from the rural to urban centres for various forms of exploitative work and or activities such as: prostitution, forced labour (as domestic servants), factory workers, workers in plantations and construction companies, drug peddlers, pick-pockets, waiters, among several others ([40], p. 4).

In contrast to the internal dimension, international trafficking takes the form of recruitment and movement of people from one country to another (cross-border trafficking) for the purpose of exploitation. The nature of exploitation in this form is also similar to the domestic form but in greater proportion. The demands are higher so also are the costs and implications. For most of the cross-border dimensions, the flows are usually between countries within the same region or neighbouring countries. Thus, the cross-border flow is not usually a distance one. However, there are instances of continental and intercontinental flows as well. According to United Nations Office on Drugs and Crime (UNDOC), contemporarily, there are evidences of victims of human trafficking from the East Asian States found in over twenty (20) countries in regions across the globe, including the Americas, the Middle East, Europe, Central Asia and Africa ([41], p. 11).

The running of this global criminal enterprise is spearheaded by transnational criminal groups that cut across the continents of the world [1,34]. These mafia groups combine drug trafficking, arms trafficking, money laundering and other forms of transnational crime with human trafficking - for both labour and sexual exploitation. According to Shelley, a combination of criminal gangs/organisations such as the Thai mafia, Indian criminal rings, Nigerian gang, Mexican group, Russian-speaking criminal ring, Albanian group and the Balkan criminal gang dominate the general human trafficking trade on a global scale [15, 34].

Regarding human trafficking for sexual exploitation, the combination of the Italian mafia families, Russian-speaking gang, Thai gang, Japanese Yakuza, the Triads, Jaotou, Jao Phro, Indian group, Sindikets (Syndicates in Malaysia), Fuk Ching in the United States dominate the trade $[15,34]$. Other lesser mafia groups that dominate the sex trafficking market include the Dominican, Filipino and Turkish gang, amongst other trafficking entrepreneurs across the globe [15, 34, 42]. 
Most of these mafia organisations, especially those from the Asian axis have a turf, a hierarchical structure, restricted membership and often use violence to enforce compliance and exert authority $[15,34]$.

Contrastively, some other criminal networks of persons in human trade and other forms of transnational organised crime operate on an ad hoc basis, with no definite structure. It is instructive to state that most of these criminal groups have built strong empires of wealth and remained in the scene. Such vibrant structures were not necessarily fabricated due to the clandestine nature of the trade, but owing largely to the loopholes in most States structures and institutions (criminal justice), especially the police and border officials through corruption.

It is instructive to state at this juncture that the scale of research on human trafficking globally has been flooded with issues of sexual exploitation. Though a relatively appreciable volume also focus on the labour aspect, and few on organ harvesting, but the proportion of sexual domain is larger. The fact, however, is that the vast majority of modern day research findings have shown swelling incidences of trafficking of persons for labour exploitation in-agriculture, manufacturing industries, block factories, mining, fishing, domestic servants, carmel jockeys, pick-pockets, street vending, to mention a few [40].

The proportion of labour exploitation varies from State to State, from person to person, and often a function of the nature of task or work to be done (by trafficked victims). Labour exploitation often manifest itself in restriction of movement, seizure and confiscation of passport, daily verbal intimidation, cycles of abuses (rape, torture, beating, etc.), low wages, deduction or no pay at all, amongst others.

Contemporarily, the issue of human trafficking in Africa is taking a new dimension with the evolving menace of human trafficking into baby factories (or 'baby farms') for baby making coming to the centre stage. Onuoha [43] revealed this new wave of human trafficking in recent times. Though he argued that the incidence has been going-on for a while now in some parts of the world, but it is rising in a crescendo manner in Nigeria. However, it is very challenging to define the concept'baby factory', 'baby farming' and 'baby harvesting' as they mean the same thing in this context, and as used by Onuoha.

Moreover, there is no legal definition for these terms since they are emerging concepts. However, according to Onuoha [43], baby factories 'are locations where young ladies or girls, some teenagers or little above that, are harboured and deliberately encouraged or forced to become pregnant and subsequently give up their babies for sale'. Put differently, baby factory is an apartment or a form of accommodation in which teenagers and/or young ladies are kept (either voluntarily or by coercion), copulated, impregnated, and after delivery, their babies are taken away from them and sold to clients, agents or couples in need of babies. This could be done sometimes with or without the consent of the victims. This episode therefore brings to the fore a new concept in the human trafficking discourse: baby trafficking.

\section{Factors contributing human trafficking in Africa}

It is pertinent to state at this juncture that the problem of trafficking often do not begin with the traffickers, but with the circumstances that force victims to seek better living conditions in environments that render them vulnerable to exploitation [44]. Contrary to the popular embellished image of trafficked persons as either kidnapped, or coerced into leaving their homes, more often than not, the initial decision to migrate is often a conscious one [6]. Such decisions are further heightened by some of the factors that bedevilled Africa as earlier indicated. 
Trafficking business thrives in Africa due to a range of precipitating factors can be broadly grouped into two-the 'push' and 'pull' factors $[6,9,10]$. The push and pull factors are two sides of the same coin-the causes of one can also be the consequence of another. While the push factors are those issues and circumstances that drive or force people into accepting demands that render them susceptible to trafficking, the pull factors encapsulate those that influence people into accepting dehumanising offers. The push factors that contribute to human trafficking in Africa include, but are not limited to poverty, political instability, greed, peer pressure, and lack of legitimate and sustainable employment opportunities and corruption [6, 45-47]. The pull factors include but are not limited to high demand for organs and body parts, the demand for cheap and low-skilled labour, the effect of globalisation, weak border control, economic disparities between developed and developing countries [19, 48-51]. It is imperative to indicate that counter-trafficking measures in many African States have considerably been ineffective because most of the strategies have rested on the tripod stand of arrest, punishment and incarceration [17]. While these measures could thrive in addressing the proximate causes of the crime, the remote causes will require proactive measures that will facilitate the process of finding a durable solution its root causes.

\section{Suggestions and conclusion}

This chapter began by underscoring the global resonance of human trafficking and its debilitating impacts on human lives, and international peace and security. It further explored the dynamics of human trafficking in Africa and the impacts of globalisation in engendering the rise and growth of trafficking businesses, in Africa as well as in other parts of the world. The factors and forces that created the artificial structures for trafficking to thrive in different parts of Africa were also identified and discussed. In addition, the root causes of human trafficking were highlighted. It also was indicated that except proactive and enduring measures are put in place at addressing those age-long root causes factors, State response to human trafficking in contemporary African States will be not be successful.

From the foregoing, to address the scourge of human trafficking in Africa, each State should first consider and find solution to the underlying or root causes of the crime. These factors are embedded in the countries' socio-economic, political, and cultural milieus. If the various African countries address these factors, it will serve as trajectories to combating the phenomenon. Such task is however a collective responsibility of all relevant stakeholders, which include, the Government, Non-Governmental Organisations (NGOs), parents, civil societies, religious and educational institutions, and human rights groups, to mention a few. 
The Conundrum of Human Trafficking in Africa

DOI: $h$ ttp://dx.doi.org/10.5772/intechopen.83820

\section{Author details}

Paul O. Bello and Adewale A. Olutola*

Department of Safety and Security Management, College of Humanities, Tshwane University of Technology, Pretoria, South Africa

*Address all correspondence to: olutolaaa@tut.ac.za

\section{IntechOpen}

(c) 2020 The Author(s). Licensee IntechOpen. This chapter is distributed under the terms of the Creative Commons Attribution License (http://creativecommons.org/licenses/ by/3.0), which permits unrestricted use, distribution, and reproduction in any medium, provided the original work is properly cited. $(\mathrm{cc}) \mathrm{BY}$ 


\section{References}

[1] UNODC. Global Report on Trafficking in Persons. New York: UNODC; 2016

[2] Walk Free Foundation. The global slavery index. 2018. Available from: https://downloads.globalslaveryindex. org/ephemeral/GSI-2018_FNL_180907_ Digital-small-p-1544412802.pdf [Accessed: 11 December 2018]

[3] Shabanju T. Human Trafficking. Workshop Report. Pretoria: IDASA; 2010

[4] Nwadike F, Ekeanyanwu N. Building sustainable peace in Africa: Nigeria in perspective. African Media and Democracy Journal. 2012;11(1). Available from: http://www. amdcjournal.net [Accessed: 30 April 2014]

[5] Bello PO, Olutola AA. Community policing as a mechanism in combating human trafficking in South Africa: Getting the priorities right. Politeia. 2016;33(1):41-60. DOI: $10.25159 / 0256-8845 / 1521$

[6] Bello PO. Examining human trafficking and the response of the South African criminal justice system [unpublished $\mathrm{PhD}$ thesis]. Pretoria: Tshwane University of Technology; 2015

[7] Adepoju A. Review of research and data on human trafficking in subSaharan Africa. International Migration. 2005;43(1/2):75-98

[8] Bello PO. Modern-day slavery: The experience of child trafficked victims in Nigeria. Child Abuse Research: A South African Journal. 2017;18(1):11-20. Available from: https://journals.co.za/ content/journal/10520/EJC-77dc174df [Accessed: 22 January 2017]

[9] HSRC. Tsireledzani: Understanding the dimensions of human trafficking in South Africa. 2010. Available from: http://www.hsrc.ac.za/en/researchdata/ktree-doc/8277 [Accessed: 20 June 2015]

[10] Mollema N. Combating human trafficking in South Africa: A comparative legal study [an unpublished doctoral thesis]. Pretoria: UNISA; 2013

[11] Oluwaniyi O. Internal Child Trafficking in Nigeria: Transcending Legal Borders. Children and Youth in the Labour Process in Africa. Dakar: CODESRIA; 2009. pp. 81-110

[12] UNESCO. Human trafficking in Nigeria: Root causes and recommendations. Policy Paper 2006;142(E)27. Paris: UNESCO. Available from: http://unesdoc.unesco. org/images/0014/001478/147844e.pdf [Accessed: 8 December 2017]

[13] United States Department of State. Trafficking in persons report. 2017. Available from: https://www.state.gov/ documents/organization/271339.pdf [Accessed: 4 October 2017]

[14] Di Nicola A. Researching into human trafficking: Issues and problems. In: Lee M, editor. Human Trafficking. Canada: Willan Publishing; 2007. pp. $49-72$

[15] Shelley L. Human Smuggling and Trafficking into Europe. A Comparative Perspective. Washington, DC: Migration Policy Institute; 2014

[16] Gould C. Cheap lives-Countering human trafficking: Considerations and constraints. South African Crime Quarterly. 2006;16:19-25

[17] Bello PO, Olutola AA. The enforcement of anti-trafficking law in South Africa: A case of an aircraft without a pilot. Police Practice and Research: An International 
Journal. 2018;18(5):1-14. DOI: 10.1080/15614263.2017.1387783

[18] Adetula V. African Conflicts, Development and Regional Organisations in Post-Cold War International System. The Annual Claude Ake Memorial Lecture. The Nordic Africa Institute: Uppsala, Sweden; 2014

[19] Shelley L. Human Trafficking: A Global Perspective. Cambridge: Cambridge; 2010

[20] UNESCO. Human trafficking in South Africa: Root causes and recommendations. Policy Paper 2007;14.5(E). Available from: http://www.unesdoc.unesco.org/ images/0014/001478/147844E.pdf [Accessed: 30 May 2013]

[21] Krieg SH. Trafficking in human beings: The European Union approach between border control law enforcement and human rights. European Law Journal. 2009;15:775-790

[22] Liebermann S, Landman K. A Manual for Community Based Crime Prevention: Making South Africa Safe. Pretoria: CSIR; 2000

[23] Luiz JM, Stewart C. Corruption, South African multinational enterprise and institutions in Africa. Journal of Business Ethics. 2014;124:383-398. DOI: 10.1007/s10551-013-1878-9 [Accessed: 8 October 2015]

[24] Onyeonoru I. Push factors in sex trafficking for internal commercial sex work and gender implications: A study of Benin, Edo State. African Journal of Peace and Conflict Studies. 2003;1:1-19

[25] Picarelli JT. Historical approaches to the trade in human beings. In: Lee M, editor. Human Trafficking. Cullompton, Devon: Willan Publishing; 2007. pp. 26-48

[26] Najemy L. South Africa's approach to the global human trafficking crisis.
An analysis of the proposed legislation and prospects of implementation. Washington Universities Global Studies Law Review. 2010;9(1)

[27] Olateru-Olagbegi B, Ikpeme A. Review of Legislations and Polices in Nigeria on Human Trafficking and Forced Labour: Action Programme Against Trafficking and Forced Labour in West Africa. Lagos: International Labour Organisation; 2006

[28] UNODC. Toolkit to Combat Trafficking in Persons. Global Programme Against Trafficking in Human Beings. Vienna: United Nations Office on Drugs and Crime; 2006

[29] Yee RJ. Capturing Tacit Knowledge: Documenting and Understanding Recent Methodological Innovation Used in Design Doctorate in Order to Inform Postgraduate Training Provision. EKSIG 2009. Newcastle: Northumbria University; 2009

[30] BBC Business News. Nigeria becomes Africa's biggest economy. 2014. Available from: http://www.bbc.com/ news/business-26913497 [Accessed: 30 May 2014]

[31] Bello PO. Criminal justice response to human trafficking in Nigeria and South Africa: Suggestions for effective performance. Contemporary Justice Review: Issues in Criminal, Social and Restorative Justice. 2018;21(2):140-158. DOI: $10.1080 / 10282580.2018 .1455507$

[32] Rossi E. Trafficking in Human Beings, Especially Women and Children in Africa. Florence, Italy: UNICEF, Innocenti Research Centre; 2003

[33] Kreston S. Trafficking in children in South Africa: An analysis of pending legislation. Child Abuse Research in South Africa. 2007;8(1):35-50

[34] United States Department of States. Trafficking in persons report. 2018. 
Available from: https://www.state.gov/ documents/organization/pdf [Accessed: 11 December 2018]

[35] International Organisation for Migration. Seduction, Sale and Slavery: Trafficking in Women and Children for Sexual Exploitation in Southern Africa. Pretoria: IOM; 2003

[36] Aronowitz A. Human Trafficking, Human Misery: The Global Trade in Human Beings. Westport CT: Praeger; 2009

[37] Lee M. Human Trafficking. Cullompton, Devon: Willan Publishing; 2007

[38] United State Department of State Report 2014. Trafficking in persons report. Available from: http://www.state.gov/documents/ organization/226844.pdf [Accessed: 13 November 2014]

[39] United State Department of State Report 2015. Trafficking in persons report. Available from: http://www.state.gov/documents/ organization/243557.pdf [Accessed: 13 November 2014]

[40] Bello P. Human trafficking as a form of human rights violation in Lagos State [unpublished dissertation]. Ibadan: University of Ibadan; 2009

[41] UNODC. 2008 Global Trends: Refugees, Asylum-Seekers, Returnees, Internally Displaced and Stateless Persons. Geneva: United Nations High Commissioner for Refugees; 2009

[42] UN.GIFT. Transnational Organised Crime: Impacts from Source to Destinations. The Vienna Forum to Fight Human Trafficking (13-15 February 2008). Vienna: UN.GIFT; 2008

[43] Onuoha FC. The evolving menace of baby factories and trafficking in Nigeria. African Security

Review. 2014;23(4):405-411. DOI:

$10.1080 / 10246029$

[44] Chuang J. Beyond a snapshot: Preventing human trafficking in the global economy. Indiana Journal of Global Legal Studies. 2006;13(1):136163. Available from: http://muse. jhu.edu/journals/gls/summary/ v013/13.1chuand.html

[45] Agbu O. Corruption and human trafficking: The Nigerian case. West African Review. 2003;43

[46] Elechi O, Okosun T, Ngwe JE. Factors vitiating against the effectiveness of the Nigeria police in combating the criminal exploitation of children and women. African Journal of Criminology and Justice Studies. 2007;3(1):1-49

[47] Adesina O. Modern day slavery: Poverty and child trafficking in Nigeria. African Identities. 2014;12:1-15

[48] Anderson B, Davidson J. Trafficking-A Demand-Led Problem? Stockholm: Save the Children; 2002

[49] Bales K. Understanding Global Slavery. Berkeley: University of California Press; 2005

[50] Hughes D. The "Natasha" trade: The transnational shadow market of trafficking in women. Journal of International Affairs. 2000;53

[51] Wheaton EM, Schauer EJ, Galli TV. Economic of human trafficking. International Migration. 2010;48(4):1-28 


\title{
Chapter 3
}

\section{Labour Trafficking and Exploitation in Rural Andalusia}

\author{
Waldimeiry Correa da Silva and Carla Cingolani
}

\begin{abstract}
This chapter presents the preliminary results of a research project, called "Research on the Vulnerability of Human Rights in Andalusian Rural Areas: Migration, Labour Treatment, and Other Forms of Exploitation for the Strengthening of Andalusian Development Agents". In the mentioned research, we analyse the trafficking in persons for the purpose of labour exploitation (labour trafficking) and labour exploitation in the rural context of Andalusia. For this, the research focuses on three (3) provinces of Andalusia in which the fieldwork is carried out in rural areas of the provinces of Almeria, Seville and Huelva. For that purpose, this study will be structured in four sections: first, the realisation of a conceptual introduction on "labour trafficking", its connection with contemporary forms of slavery and exposure of the factors that favour the development of this phenomenon in the Andalusian context; second, presentation of the partial data that allow us to make a localised diagnosis through the contextual approach of labour exploitation and labour trafficking in Andalusia; third, analysis of the results; and fourth, conclusions on the confrontation with the labour treatment in Spain.
\end{abstract}

Keywords: trafficking in human beings, labour trafficking, labour exploitation, key actors, development and mobility, human rights

\section{Introduction}

The internationally accepted definition of human trafficking [HT] or trafficking in persons is recent (established in 2000), wide (it does not bind the behaviours which define it) and complex (it involves a process made up of three stages: an action that has coercive, violent or fraudulent means that ultimately results in exploitation $^{1}$ ). Based on this, HT is observed to be an action which involves the

\footnotetext{
${ }^{1}$ The concept of Human Trafficking is defined in Protocol to Prevent, Suppress and Punish Trafficking in Persons Especially Women and Children, supplementing the United Nations Convention against Transnational Organised Crime, adopted and opened for signature, ratification and accession by General Assembly Resolution 55/25 of 15 November 2000 (Palermo Protocol). In its Article $3^{\circ}$ decreed (a) 'Trafficking in persons' shall mean the recruitment, transportation, transfer, harbouring or receipt of persons, by means of the threat or use of force or other forms of coercion, of abduction, of fraud, of deception, of the abuse of power or of a position of vulnerability or of the giving or receiving of payments or benefits to achieve the consent of a person having control over another person, for the purpose of exploitation. Exploitation shall include, at a minimum, the exploitation of the prostitution of others or other forms of sexual exploitation, forced labour or services, slavery or practices similar to slavery, servitude or the removal of organs".
} 
movement of persons (transfer, reception, accommodation, etc.) by coercive, violent or fraudulent means, with the intention of directly or indirectly exploiting them [1]. The movement generally occurs within a migratory context, either regular or irregular. This can lead to confusion with other legal categories, such as illegal migration, trafficking in persons or international asylum. ${ }^{2}$

As previously mentioned, the definition of HT provided by the Palermo Protocol contains three base elements: an action, the means and a purpose of exploitation. These elements are all interrelated. Therefore, we start with a definition of HT that does not describe one solitary act with a specific result but rather an entire process of capture, transport and control, which can be organised in multiple ways and involve a range of different actions and results ([2], p. 11). In its entirety, the definition specifies that the process begins with a specific action of a trafficker who utilises deceptive means to take advantage of a situation of vulnerability originated in a context of personal insecurity. These two initial actions ultimately determine the process of exploitation. The human being is reified, and their rights to not be enslaved are violated, as well as their rights against inhuman and degrading treatment. This reinforces the threatening situation to a person's security and generates vulnerability.

For an integral approach to HT, it is necessary to understand the systemic factors as well as the actions which lead to their causes. These are generally related to poverty, discrimination against women and the political and institutional inability to protect victims and persecute traffickers $[1,3]$. Thus, when discussing HT, it is important to take into consideration the complexity and the multidimensional nature of this phenomenon. When confronting this issue, it is also essential to start from a multidisciplinary perspective, which extends beyond the migratory problem or unlawful activity that entails the practice of a crime or a violation of rights. It is also important not to discount the fact that this involves a violation of rights that is legitimised by a lack of conscience, sociocultural behaviour and lucrative economical transactions for exploitation.

From the basis of the concept of HT, we will analyse human trafficking for labour exploitation (labour trafficking) and labour exploitation in rural Andalusia. This will be from the context of human mobility in three provinces of the region (Seville, Huelva and Almeria). We will present a conceptual and contextual framework that enables the possibility of the existence of HT in Andalusia. As well, we will propose that to eradicate this social scourge; there is a necessity for the proactive participation of different social actors. Their assistance will aid in tackling the inter-sectorial and multidimensional challenge that entails human trafficking.

\section{Conceptual framework about human trafficking for labour exploitation (labour trafficking)}

One of the criticisms to the Palermo Protocol is that it does not define terms such as "exploitation". It does not specify what "labour trafficking" is or that it is a means in itself. The protocol alludes to "slavery, servitude and forced labour" as being the main manifestations of this type of trafficking [1]. The above-mentioned behaviours point to the current internationally recognised legal concepts that let us prosecute the labour trafficking crime. Based on this, this study

\footnotetext{
${ }^{2}$ For more information on the relationship between trafficking in persons and migration in the context of human mobility $[1,3]$.
} 
considers labour trafficking to be the capture of people with the purpose to subject them to forced labour or services, servitude or a contemporary version of slavery, by means of coercion, trickery, force, abuse of power or state of vulnerability ${ }^{3}$.

In practice, the distinction between the concepts of forced work, slavery and practices similar to slavery and servitude is subtle and not very helpful with respect to human rights protection [4] \$282. Based on these considerations, five characteristics should be taken into account to determine whether a case is to be considered as labour exploitation:

- First: Threat of physical, sexual or emotional violence. For example, in the instance of emotional violence, this could include blackmail, reproaches and/or insults.

- Second: Restriction of victim's movements to a limited zone or imprisonment in their workplace [4] $\$ 116-120$.

- Third: Servitude due to debts or servile work [5]§145, retention of salary or refusal of payment.

- Fourth: Seizure of passports and identity documents, so that the worker cannot leave or confirm their identity and situation [4] $\mathbb{9} 93^{4}$.

- Fifth: Threat of report to authorities [6] \ 281.

To evaluate the existence of labour trafficking, it is helpful to consider that an apparent "voluntary offer" of a worker or victim can derive from manipulation and not be based on an informed decision. Likewise, it is possible that the exploited person is recruited willingly and that the coercive actions to maintain a person in a state of restraint or exploitation arise afterwards.

Presently, this is one of the most common forms of labour trafficking ${ }^{5}$. It is therefore important to name the most common types of crimes and violations of human rights which can be sourced from the Palermo Protocol. In the European context, these are included in the three most severe forms of labour exploitation: slavery, servitude and forced or compulsory work ${ }^{6}$. In national legislations, labour

\footnotetext{
${ }^{3}$ This direction also directs the International Organisation for Migration [7]. Available in <http://www. iom.int/files/live/sites/iom/files/pbn/docs/INFORME_OIM.pdf>.

${ }^{4}$ In 2005, the ECHR verified the merit of the case in which the plaintiff alleges that I had her passport withheld, worked without pay, suffered cultural, physical and mental isolation. He adds that the fact that his situation has not been a temporary and occasional event (as generally occurs in terms of "forced or compulsory labour"). Her freedom to come and go was limited, she was in a precarious situation and administrative irregularity with the constant fear of being arrested and deported. Given the facts, he adds that the situation of contemporary slavery is characterised by (a) exploitation of unpaid work by a person, (b) status or condition of exercising control over the life of the person, (c) degree of restriction or freedom of movement and (d) The power to freely make decisions [4] §93-96.

${ }^{5}$ According to the UNDOC report, 2016, 38\% of detected cases of HT are for labour exploitation. However, there are areas, such as Eastern Europe or Central Asia, which is the equivalent of $64 \%$ of detected cases. In South America 29\%, North America 39\%, in Africa 53\%, Central Europe and the South $30 \%$ two cases [8].

${ }^{6}$ Included in Article 5 of the European Charter of Fundamental Rights, which corresponds to Article 4 of the European Convention on Human Rights.
} 
exploitation is considered to be an independent crime ${ }^{7}$. A person is sanctioned for illegally directly or indirectly obtaining unjustifiable benefits of an economic nature or otherwise; making use of other's labour; subjecting workers to practices that are offensive to their dignity, for example, dangerous or unhealthy conditions; where there is an evident disproportion between the amount of work completed by workers and the amount they are paid; or when the salary is below the legal minimum.

In the mentioned cases, the four types of labour trafficking are described: forced labour, exhausting work day, degrading work conditions and servitude due to debt. In the first type, forced labour occurs when a person is coerced into exploitative work conditions, where they lack the ability to leave the workplace either due to debts, threats or physical or psychological violence. The second, the exhausting work day, refers to a draining job which extends beyond working overtime. This ultimately places the physical integrity of a worker at risk as the interval between shifts is not sufficient for the worker to rest and regain their energy. In many cases, the weekly break is not even observed, which prevents the worker from maintaining a social or family life. The third type, servitude due to debt, refers to allegedly illegal debts acquired from transport, food, rent and work tool expenses. Through this exploitative artifice, all these different items are charged in an excessive manner and discounted from the worker's salary, who thus remains burdened by a fraudulent debt. This conduct, similar to slavery, is also understood to be a form of aggravated forced labour which involves the following four elements: (i) that "the work is voluntarily accepted, (ii) that the value of the work is insufficient to settle the debt, (iii) that the duration of the work is unlimited and (iv) that the nature of the service is indefinite" (IACHR: Trabalhadores da Fazenda Brasil Verde vs. Brasil, 2016, \$ $231)^{8}$. This only concerns the types of debt that are uncertain, lack a time limit and eventually become unpayable. The fourth type, the degrading conditions ${ }^{9}$, is defined as a set of irregular contraptions that offends their dignity and characterises the precariousness of the living conditions workers are subjected to. This includes precarious accommodation, lack of medical assistance, deplorable food, lack of basic sanitation and drinking water ${ }^{10}$, violence and mistreatment, as well as other aspects which curtail the worker's freedom such as retention of pay, geographical isolation and retention of identity documents ${ }^{11}$. Therefore, we begin from "the interconnectedness of the practices of exploitation, namely,

\footnotetext{
7 In the Spanish case, the purpose of labour exploitation, regardless of sexual activity, must be framed within the following modalities, as defined by article 177bis. 1, a): "the imposition of forced labour or services, slavery or practices similar to slavery or bondage or begging” [9].

8 See also [4] $₫ 82$ to 149.

9 In accordance of Inter-American Court of Human Rights (IACHR): [5] § 145.

${ }^{10}$ As ruled in the judgement of the IACHR [4]: Trabalhadores da Fazenda Brasil Verde vs. Brasil: "Ao chegar à fazenda, os trabalhadores são alojados em barracas cobertas de plástico e palha, sem proteção lateral [...] A água que bebem [...] não é própria para consumo humano, pois serve de local de banho e bebedouro de animais da fazenda [...] A alimentação, como a carne exposta aos insetos e à intempérie $[\ldots] ” .(2016, \$ 145)$. See also $\$ 160$.

${ }^{11}$ IACHR: Audiência Pública. Trabajadores de la Hacienda Brasil Verde vs. Brazil. Parte 2. Available in<https://vimeo.com/156347137>. Especially the statement of the expert Raquel Dodge. See also "part 1" where the expert Leonardo Sakamoto exposes the permissive Brazilian systemic context to this practice and also the exposition of the perito Cesar Rodriguez Garavito on the clarification of concepts related to the contemporary forms of slavery and forced labour. Available in <https://vimeo.com/156320295>.
} 
the overlapping of questions of citizenship, migratory status, precarious work conditions and/or lack of protection at the workplace" [10]. Nonetheless, as we said before, we do not consider them to be practices of similar nature, though they can overlap and establish negative synergy [1]. Studies regarding labour trafficking address five common assumptions of this crime [11]. The first is that labour trafficking does not occur in a large scale. This is an incorrect assumption, though labour trafficking is overshadowed by other types of HT, such as sexual trafficking and exploitation ${ }^{12}$. The second is the lack of realisation that labour trafficking may derive from a frustrated migratory process. It can be observed that there is no official data certifying how many people involved in the context of human migration have possibly been dragged into labour trafficking, either victims of trafficking, asylum seekers, illegal migration or forced displacement. The third is the lack of leadership from states regarding this type of trafficking. This generates underreporting and subsequently renders the victims of labour trafficking invisible. The fourth is the lack of an "organised group" 13 and the "fraudulent and/or coercive means". In the majority of cases, the worker is indirectly contracted by an agency, to which they have been referred by family members or directly by the employer [12]. The fifth refers to the second constitutional element of HT, the means. In this instance, there may be no direct threat of violence or coercion. Nevertheless, servitude, seizure of documents, intimidation and constant threats are used which restrict the freedom and autonomy of an individual.

\begin{abstract}
"The above-mentioned specific knowledge concerning the crime's true nature substantiates that (i) the crime does exist and in a significant portion of the labour market; (ii) it is not necessarily part of illegal migration, including (a) entry in a country through legal channels, (b) victims may work legally or reside legally but work illegally and (c) victims may also be nationals; (iii) women, men and boys can be victims; (iv) perpetrators are individuals as well as criminal groups; and (v) generally more subtle means are deployed than in women trafficking for sexual exploitation. These findings provide a true appreciation of the crime and provoke, from this perspective, an examination of current national legislation and adjudication, as follows" [11].
\end{abstract}

\footnotetext{
${ }_{12}$ In Voorhout's words: "Moreover, the victims of this crime, both female and male, are to be found in almost all sectors and industries imaginable.36 For instance: (i) domestic work, including care/nursing, au pairs and in forced marriages working for different 'relatives'; (ii) construction work, also renovation; (iii) hospitality services, e.g. restaurants, bars, cafeterias, and night shops; (iv) agriculture and horticulture, e.g. the fruit sector and greenhouse farming, in the Netherlands; (v) food industry work, ranging from food processing and packaging to slaughter work; (vi) automotive and ship work, such as professional transport by road, cabs, car washes, and work in ports; (vii) the textile industry, such as laundry work and sorting out second-hand clothes. Some were forced to commit crimes, for instance, shoplifting, pick-pocketing and the sale of pirate CDs and DVDs. Additionally, anecdotal information is available on cleaning companies, private employment agencies including illegal labour subcontractors, door-to-door distribution of advertisement leaflets and exploitation of foreign football players, in Belgium" [11].

${ }^{13}$ For example, objectives under policy subarea 1 in the evaluation of EU policies on freedom, security and justice (COM/2006/0332 final), and point 45 , under 1.3.2. on the report on the implementation of the Hague programme for 2005 (COM/2006/0333 final) [2, 13-17].
} 
In Spain, the penal laws on labour trafficking also pose problems in other legal fields, such as labour ${ }^{14}$, migration and human rights. ${ }^{15}$ As regards to the exploitation of immigrants, their irregular situation constitutes an important risk factor for Spain. ${ }^{16}$ In the case of Spain, the main economic sectors where labour trafficking prevails are agriculture, forestry, fishing, hospitality and domestic work [18].

This negative synergy exists all around the world. Nevertheless, it is more complex within the EU. The EU citizenship allows its residents to move freely within its member-states [13]. Subsequently, it does not have border controls for its workers, who enjoy standards of labour and social protection-which are based on human rights. The starting premise is that immigration to the UE is restricted, with the aim of protecting the area of free movement. This clashes with the paradox of labour markets which demand more unskilled workers, to work in areas (e.g. rural) where the local workforce is not willing to go.

Though there may seem to be an apparent difficulty, the EU has up-to-date tools to proactively confront the problem of labour trafficking. For this to be effective at a domestic level, regional and national tools must be harmonised for a coordinated action that defends the rights to dignified work. Criminal investigations can be facilitated, for example, by transnational cooperation between the joint investigation teams of the security corps and forces of member states. They can also be assisted by the EU by virtue of Europol, the European police agency. ${ }^{17}$ This can also encompass (a) monetary investigations regarding legal entities which allow criminal earnings to be confiscated $[19]^{18}$ and (b) actions which are directed to criminal organisations [20]. The combined efforts of the prosecutors and Eurojust [21] provide an effective means of combat. Both could possibly make use of Europe-wide arrest warrants that allow judiciary authorities to execute warrants issued by other member states against alleged traffickers ${ }^{19}$. Lastly, the UE measures should also be judged. A large assistance and protection body exists for victims, though it cannot be considered entirely satisfactory. It appears that it prefers to carry out a criminal investigation rather than providing effective protection for victims ${ }^{20}$. Both reasons indicate that it is necessary to come to a uniform interpretation of the definition.

\footnotetext{
${ }^{14}$ Article 311 of the Spanish Penal Code criminalises the imposition to workers by deception or abuse of necessity, of working conditions that harm, suppress or restrict their rights. Similarly, article 312 criminalises trafficking in illegal labour (L.O 1/2015), delves into the protection of workers' rights and introduces specific precautions for foreign citizens and minors (311bis). Article 177bis, expressly criminalises the recruitment, transportation, transfer or reception of national or foreign persons, through violence, intimidation or deception, or abusing a situation of superiority, necessity or vulnerability of the victim in order to impose forced labour or services, slavery or practices similar to slavery, servitude or begging or sexually exploit, including pornography.

15 El artículo 607 bis (10) del Código Penal Español castiga la esclavitud como un crimen de lesa humanidad. Este delito se castiga con pena de prisión de cuatro a ocho años.

16 According to the report of the European Agency of Fundamental Rights: "Severe labour exploitation: workers moving within or into the European Union". Available in: http://fra.europa.eu/en/ publication/2015/severe-labour-exploitation-workers-moving-within-or-european-union.

17 Eurojust. Annual Report 2006. Eurojust and human trafficking, the state of affairs. Produced for Eurojust, under auspices of the Dutch Desk at Eurojust Boudewijn de Jonge, October 2005, p.25. Available in https://polis.osce.org/node/7956.

${ }^{18}$ However, not all EU member states have uniform sentences; see Section 4.

19 Article 2 Council Framework Decision (2002/584/JHA, OJ L 190/1, 18.7.2002).

${ }^{20}$ Council Framework Decision (2001/220/JHA, OJ L 82/1, 22.3.2001) and Joint Action 98/733/

JHA. Implementation by all EU member states of the COE Convention, which offers more victim and witness protection, is recommended.
} 


\section{Participative and collaborative methodology}

This study used a plan to gather data from key public and private actors and exploited workers, in conjunction with fieldwork. Through a contextual approach, a localised diagnostic study was produced, with the objective of discovering labour exploitation and labour trafficking in Andalusia. It also aimed to emphasise the importance of development agents ${ }^{21}$. To prepare for this diagnostic study, a work programme was designed. This programme aimed to compile, organise and analyse the information given by stakeholders capable of detecting and giving access to justice and assistance to victims of labour trafficking. This programme also utilised information from other sources, such as academic studies and non-governmental research.

\subsection{Stages of the investigation}

The investigation was planned to be conducted between May 2017 and September 2019. The investigation was divided into four stages and utilised the following methods:

1. The first stage was an office investigation which revised all available documents for the three provinces of the region. It also examined the specific types of HT which aimed to exploit workers. The information reviewed was sourced from governmental bodies: trafficking unit (General Office of Prosecution); Security Forces and Corps, Department of Migratory Policies/Labour, Women's Institute; and non-governmental organisations from Seville, Huelva and Almeria.

2. The second stage consisted of 13 semi-structured interviews. They were carried out with the assistance of civil workers who had an understanding of the topic of HT for sexual exploitation but knew little of the topic of labour trafficking. In this stage, youth workshops were also conducted across the three provinces. During the workshops, formative and summative questionnaires were completed by 436 youths from five institutions ${ }^{22}$ that participated in these workshops.

3. The third stage was a non-participative observation. It consisted of 4 workshops with 11 women who had migrated to the province of Almeria.

4. The fourth stage comprised of workshops with youth from the three provinces.

In this chapter we focused on the third stage. In this step, it is being concurrently implemented and looks to characterise and explore scenarios of labour trafficking in rural Andalusia. This will facilitate:

a. The characterisation of scenarios that are auspicious to human trafficking with the intent of labour exploitation

\footnotetext{
${ }^{21}$ Development agents are a relatively new profession in Spain which aims to focus and encourage development projects in different issues.

${ }^{22}$ The institutions that were surveyed among the young population have been the Universidad Pablo de Olavide, Universidad de Huelva, Universidad Loyola Andalucía, and Universidad de Almería. The course or grade of students has been professional training courses Isbylia. Twelve different degrees: international relations (IR), business management + IR, political science, social sciences, communication + IR, criminology, law + IR, economy +RRII, child education, social education, social integration and social work.
} 
b.Information of victims which could be interviewed in this investigation

c. Work with key development agents to amplify awareness and understanding of labour trafficking and exploitation in the rural contexts of Andalusia

For this, 2 workshops have already been conducted in Almeria, where 15 migrant women participated in 4 sessions. Similarly, 4 workshops were run in Huelva, where 10 women participated. No workshops with potential HT victims were able to be organised within the province of Seville as there was no possibility to access the selected agricultural farms ${ }^{23}$.

The information was sourced in the first stage between September 2017 and August 2018. However, preparatory work occurred in the previous months, including gathering of bibliography, legislation and news regarding the matter. In this stage, various institutions were contacted, and meetings took place to coordinate and identify interviewees. The second and third stages were carried out between March and October of 2018.

\section{Preliminary fieldwork results: workshops with migrant women}

Two techniques were utilised for the first and second stages. Firstly, a questionnaire was developed for institutions and civil organisations who are in contact with the phenomenon of labour trafficking. The questionnaire aimed to evaluate this issue and to obtain information about specific cases identified. In particular, the behaviour and characteristics are most common to them, as well as the services offered and the needs detected. This questionnaire was complemented with semi-structured interviews with key actors who work in different fields to combat trafficking. The interviews' main objective was to evaluate how much certain institutions know about this phenomenon. It also aimed to comprehend the various perceptions exhibited by the participants involved in this process. Thus, public service institutions were contacted, including police, judiciary and workplace inspection institutions and non-government institutions such as unions, migrant associations and civilian organisations.

In the third stage, workshops in the provinces of Huelva and Almeria were conducted with potential victims of labour trafficking or other forms of exploitation. The objective was to determine whether the migrant population working in the agricultural fields of Almeria was susceptible to becoming victims of labour trafficking. For these sessions, two approaches were used. On one part, a lawyer of $\mathrm{MZC}^{24}$ Almeria, accompanied by an intern student, carried out personal interviews with each of the participants. Utilising the labour trafficking indicators dictated by the International Labour Organization $(2009)^{25}$, she extracted information regarding the indicators of oppression, exploitation, resilience and vulnerability.

At the same time, as the personal interviews, a psychologist from the Almeria organisation, and an intern student, conducted group sessions with different

\footnotetext{
${ }^{23}$ MZC has been requested to the Red Cross, an entity that enters in the rural setting in Seville, which we could meet to raise synergies and be able to access the population of these areas, but finally there was no response. Therefore, from MZC we have seen the possibility of covering this lack with interviews to the different entities and institutions of the province of Seville.

24 TN: Mujeres en Zona de Conflicto, NGO who works with women in conflict zones.

25 Available in: http://www.ilo.org/wcmsp5/groups/public/@ed_norm/@declaration/documents/publication/wcms_10 5023.pdf.
} 

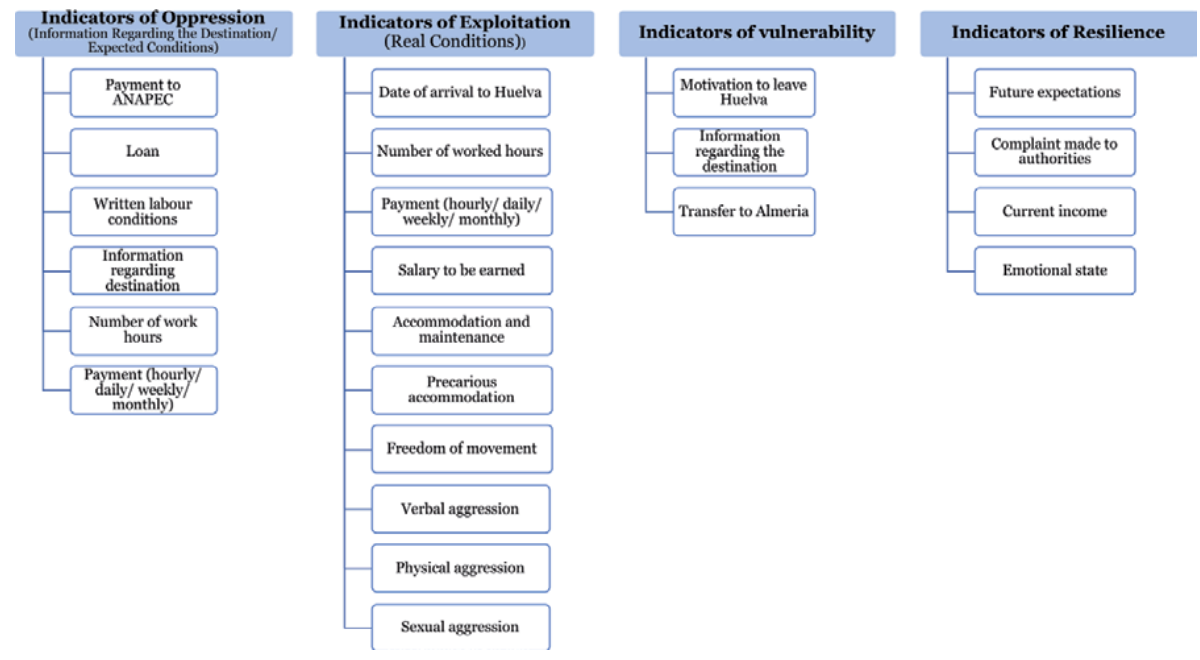

Figure 1.

Labour exploitation indicators in rural Andalusia. Based on the indicators of labour trafficking and offered by the International Labour Organisation [http://www.ilo.org/wcmsp5/groups/public/@ed_norm/@declaration/ documents/publication/woms_105023.pdf] and the workshops held with women workers, the authors have elaborated this diagram. ANAPEC Maroc, Moroccan institution that seeks to promote employment and skills.

activities. These included language classes, different migration projects and the expectations and reality of living in Spain. These sessions had some limitations, with the main one being language. None of the participants spoke Spanish.

Therefore, we had to contact Moroccan interpreters which sometimes hindered the intervention. The second limitation that we discovered was that the women did not trust their colleagues. Hence, we were able to obtain more precise information from the personal fieldwork with the participants. This could then be contrasted to, or complemented with, the information obtained in the group sessions.

We conducted a total of 9 sessions and interviewed 11 women. According to the workshops' results, we make two observations which allow us to interpret the indicators of labour trafficking and/or labour exploitation. Figure 1 illustrates these indicators. Firstly, it can be confirmed that the profile of victims of labour trafficking are women, usually in an irregular administrative situation, or that have their permit nearly expired, married or separated, with dependent children.

Secondly, it is noted that there is a possible initial irregularity within the hiring process. This is because the women (a) are not given a written contract; (b) are not aware of how many hours they will work, how many they will be given for rest, how they will be paid (per hour/daily/weekly/monthly) or the agreed rate for their completed work; (c) are not informed of the destination where they will be working $^{26}$; and (d) denounce that their employer does not meet their obligation to provide adequate accommodation. The women confirmed that they lived in overcrowded conditions, without any running water, electricity or waste management facilities (unhealthy conditions and lack of hygiene). Similarly, the sector fails to give their workers access to medical services. Many of the women have no doctor to go to. The majority of the women suffer from verbal and physical abuse from their supervisors. There have also been reports of sexual abuse from the people in

\footnotetext{
${ }^{26}$ Según confirma las mujeres trabajadoras, no saben que van a Huelva, solo que van a trabajar en España.
} 
charge. ${ }^{27}$ Similarly, two relevant clues can be added. Firstly, women have been fired before the end of their work contract as "there was no more work", or they have left the workplace due to conditions they considered to be exploitative. Secondly, there is a confirmed transit of seasonal workers from Huelva to Almeria. Nonetheless, it is not known how the idea that work can be found in Almeria disseminates. It is not known either how this transfer of workforce between the two regions is organised. It is believed that the majority occurs through private taxis. In this sense, it is necessary to further investigate how the information of work in Almeria circulates and this phenomenon of using private taxis, as they are very expensive.

We cannot present the results of the study without commenting on the obstacles we encountered during the investigation. These, in turn, have undoubtedly affected the results of the study. It is essential to mention certain aspects as they must be taken into consideration during the final evaluation of the study. These are related to the very topic of analysis and the circumstances of development of the project.

The main methodological limitation of the study originates from the understanding and use of term "human trafficking". This confusion of terminology is due to the legal Spanish definition of the term as well as operational issues. The term trafficking in persons was used in the Spanish legal framework (until 2015) to describe a situation of human trafficking, according to the definition of international legal instruments. This will be further analysed in a future stage of this study. For the purpose of this publication, the internationally accepted definitions of "human trafficking" and "trafficking in persons" were utilised, as defined in Article 3 of the Protocol to Prevent, Suppress and Punish Trafficking in Persons Especially Women and Children and in Article 3 of the Protocol against the Smuggling of Migrants by Land, Sea and Air, supplementing the United Nations Convention against Transnational Organised Crime of 2000, respectively. Throughout the study, we were able to verify that both mass media and many people who participated in workshops or had been interviewed as representatives of the institutions fighting against HT did not seem to have internalised these concepts. This is an important restriction when delineating the limit between both concepts. It also limits the demarcation of aspects that identify and characterise labour trafficking.

On the other hand, the fact that this phenomenon has not been seriously considered by institutions or society in general makes extracting further information regarding the issue and its characteristics even more difficult. This is in spite of the fact that there exists an increasing concern about the issue from an international point of view. In the first place, it has been difficult to identify professionals who are active in this field and have a significant understanding of the phenomenon. Secondly, it has been challenging to interview an equivalent number of professionals from state-run institutions and society in general. A large percentage of the total number of organisations contacted for this study was reluctant to participate. This was due to the fact that many lacked specific information on the topic, did not know about any concrete cases or had a complete dearth of knowledge of the topic. Considering that this study deals with organisations who are in the field of immigration or fighting against HT, the fact that they are not connecting the violation of dignified work and the necessary interaction with the bodies of work inspection highlight the invisibility of the phenomenon. It also highlights the

\footnotetext{
${ }^{27}$ Se tiene la sospecha de que los “favores sexuales” son práctica habitual, para la obtención de mejoras en las condiciones laborales o a cambio de alimentos. Asimismo, un informe independiente realizado por la fundación CEPAIM constata abusos laborales y sexuales en la fresa de Huelva, cf.: https://www. elmundo.es/andalucia/2018/06/12/5b1eb051e2704e461b8b460c.html; https://www.elmundo.es/andaluci a/2019/04/22/5cbe025521efa07e488b46d3.html.
} 
practical difficulties for identifying and understanding the real situation of labour trafficking in Spain.

Lastly, as HT is an incredibly complex problem about which there is little knowledge $^{28}$, we have found it challenging to collect a significant amount of information in a short time frame. Correspondingly, we have not been able to delve into the obtained results and analyse the findings with as much detail and amplitude as possible. The gathering and sorting of information planned for the future will aid us in progressing with the study, further boosting the results and assisting in the evaluation of the proposal. As a consequence of all of this, this study should be considered as exploratory in nature and, most of all, as a step forward in the path of identifying the current situation of labour trafficking in Andalusia.

\section{Final reflections: challenges regarding the research topic and the path to knowledge}

Taking into account that the problem of labour trafficking has been minimally investigated, this study is merely of an exploratory nature. It has a clear disposition to approach the phenomenon of labour trafficking and exploitation in rural Andalusia. By means of systematising, integrating and analysing available data, this study contributes to lay the basis of understanding from the perspective of the Andalusian reality. In general terms, the exploratory nature of this study has permitted the elaboration of a state of this matter, starting from existing theoretical and conceptual elements, as well as the recounts and experiences of the interviewed persons, workshop participants and questionnaire respondents.

Additionally, we emphasise at least four obstacles encountered during the development of this investigation. First, the information on labour traffic available from the public administration and society in general is very limited. In this sense, the special attention which has traditionally been applied to human trafficking for the purpose of sexual exploitation can be one of the main reasons as to why there is a lack of acknowledgement and documentation on the topic of labour trafficking. From this, we observe a second limitation, constant scarcity of information, education and training regarding this type of human trafficking. Third, the institutions that are supposedly responsible for the prevention and suppression of this type of trafficking are still in the process of acquiring the abilities required to tackle in future the complexity of such a crime and all its manifestations; this is because it has recently been criminalised in the Spanish context (2015). In this sense, we observe that one of the most noticeable voids is the lack of mainstreaming of issues relating to labour trafficking. This has led institutions, such as the Attorney General of Spain and the security corps and forces, to have limited competences for investigating and prosecuting this crime.

\section{Acknowledgements}

The authors are grateful for the support of the Andalusian Agency for International Development Cooperation for the subsidy granted to support this project. The grant has made possible the realisation of this study which is part

\footnotetext{
${ }^{28}$ As noted by Cockbain et al. "Numerous and diverse barriers to tackling labour trafficking were reported, including inadequate resourcing, limited awareness, unmet training needs, insufficient information sharing, ineffective collaboration, corruption and confusion around what constitutes labour trafficking in the first place" [22].
} 
of the project "Investigación sobre la vulneración de los derechos humanos en zonas rurales andaluzas: migración, trata laboural, y otras formas de explotación, para el fortalecimiento de los agentes andaluces de desarrollo" Ref.: 0I008/2016. Subsidised by the "Agencia Andaluza de Cooperación Internacional al Desarrollo" (AACID), 2017-2019, in which the authors are the principal investigators.

\section{Author details}

Waldimeiry Correa da Silva ${ }^{1,2 *}$ and Carla Cingolani ${ }^{3}$

1 Department of International Studies, Universidad Loyola, Andalucía, Spain

$2 \mathrm{PhD}$ in International Public Law and International Relations

3 Asociación Mujeres en Zona de Conflicto (MZC), Spain

*Address all correspondence to: wcorrea@uloyola.es

\section{IntechOpen}

(C) 2020 The Author(s). Licensee IntechOpen. This chapter is distributed under the terms of the Creative Commons Attribution License (http://creativecommons.org/licenses/ by/3.0), which permits unrestricted use, distribution, and reproduction in any medium, provided the original work is properly cited. (cc) BY 


\section{References}

[1] Correa da Silva W. Regime Internacional de Enfrentamento ao Tráfico de Pessoas. Avanços e desafios para a proteção dos direitos humanos. Lumen Juris: Rio de Janeiro; 2018

[2] O'Connell Davidson J. Trafficking, modern slavery and the human security agenda. Human Security Journal. 2008;6

[3] Correa da Silva W. Tráfico Humano en el contexto de crisis migratoria del Mediterráneo: Riesgos y amenazas para la protección de los Derechos Humanos. In: Romero Velasco M, editor. Nuevos HorizontesY Perspectivas Para El Derecho En El Siglo XXI. Pamplona: Thomson Reuters Aranzadi; 2018. pp. 95-115

[4] ECHR. Case Siliadin Vs. Francia, No. $73316 / 01$. Sentencia de 26 de julio de 2005

[5] IACHR. Caso Trabalhadores da Fazenda Brasil Verde vs. Brasil. San Jose/ Costa Rica; 2016

[6] ECHR. Case Rantsev v. Cyprus and Russia. Application n. 25965/04. Judgment. Strasbourg; 07 January 2010

[7] OIM. La trata de personas en la modalidad de explotación laboral en Costa Rica. Costa Rica; 2011. Disponível em: http://www.iom.int/files/live/sites/ iom/files/pbn/docs/INFORME_OIM.pdf

[8] UNDOC. Global Report on Trafficking in Persons 2016. New York: United Nations; 2016. Disponible en: http://www.unodc.org/documents/ data-and-analysis/glotip/2016_Global_ Report_on_Trafficking_in_Persons.pdf

[9] Cintas EP. El delito de la trata de seres humanos con la finalidad de explotación laboral. RECPC. 2011;13-15

[10] Piper N, Segrave M, NapierMoore R. What's in a name?
Distinguishing forced labour, trafficking and slavery. Anti-Trafficking Review, Special Issue, Forced Labour and Human Trafficking. 2015;5

[11] Voorhout JEBC. Human trafficking for labour exploitation: Interpreting the crime. Ultrech law Review. 2007;3(2)

[12] Anderson B, O'Connell

Davidson J. Is Trafficking in Human

Beings Demand Driven?: A Multi-

Country Pilot Study. Geneva: OIM; 2003

[13] EUROJUST. Eurojust and human trafficking, the state of affairs. In:

Annual Report 2006. Produced for Eurojust, under auspices of the Dutch Desk at Eurojust Boudewijn de Jonge; October 2005. p. 25. Disponible en: https://polis.osce.org/node/7956

[14] European Commission.

The EU Strategy towards the Eradication of Trafficking in Human Beings 2012-2016. Brussels: European Commission; 2012

[15] European Commission. Report on the progress made in the fight against trafficking in human beings (2016) as required under Article 20 of Directive 2011/36/EU on preventing and combating trafficking in human beings and protecting its victims. 2016

[16] Gozdziak E, Bump M. Data and Research on Human Trafficking: Bibliography of Research-Based Literature. Washington, DC: Georgetown University; 2008

[17] OSCE. A Summary of Challenges Facing Legal Responses to Human Trafficking for Labour Exploitation in the OSCE Region. 2017

[18] ACCEM. La Trata de Personas con Fines de Explotación Laboral: Un estudio de aproximación a la realidad en España. 2006. 
[19] UE: 98/699/JHA, OJ L 333. 9.12.1998.

However, not all EU Member States have uniform sentences, see Section 4

[20] UE: 98/733/JHA, OJ L 351.

29.12.1998

[21] UE: Joint Action 98/428/JHA OJ L 191, 7.7.1998. pp. 4-7

[22] Cockbain E, Bowers K, Dimitrova G. Human trafficking for labour exploitation: The results of a two-phase systematic review mapping the European evidence base and synthesising key scientific research evidence. Journal of Experimental Criminology. 2018;14:319-360 


\title{
Chapter 4
}

\section{Slavery and Slave Codes in Overseas Empires}

\author{
Giuseppe Patisso and Fausto Ermete Carbone
}

\begin{abstract}
The paper proposed aims to analyze the slavery legislation born between the fifteenth and nineteenth centuries, the so-called Black Codes laws-enacted in all the greatest colonial powers of the Old Continent-which regulated life and transportation of slaves in the colonies. Spain, Portugal, England and France, between the sixteenth and seventeenth centuries, created legislative codes dedicated to the slave's management in the colonies, which regulated all aspects of their life: from religion to marriage, from cohabitation to imprisonment, from crimes to corporal punishment. Particularly widespread in the Caribbean colonies of the seventeenth century, these slave laws were soon in force in almost all American colonies of European monarchies, forming the legal basis on which the slave societies of the European empires were founded. In the wake of the Spanish, Portuguese, English and French slave codes, even states that had a marginal role in the process of overseas colonization enacted similar slave codes. It was the case, for example, of Denmark and Sweden that in the management of some of their ultramarine possessions adopted slave codes inspired by those of the greatest colonizing powers.
\end{abstract}

Keywords: overseas empires, Atlantic slavery, slave laws, colonization process, America, Caribbean

\section{Introduction}

Between the fifteenth and nineteenth centuries, many European states tried to build their own overseas empire. The political, economic, social and anthropological implications of this long and complex process were innumerable. New lands were discovered and colonized, new systems of government were instituted, and new social models were created. Many of the institutions that had governed the societies of the Old World for centuries experienced substantial transformations, among which was slavery [1].

Before the period of European colonial expansion, it cannot be said that slavery was an unknown phenomenon in European society [2-4]. It was, however, an institution profoundly different from the one that gradually emerged in overseas colonies. Slaves were mainly employed as domestic servants or as laborers in artisan workshops, rarely as workforce in plantations or mines. The reduction to slavery, trafficking and exploitation of slave labor were certainly widespread practices throughout medieval Europe, but their importance-in demographic and socioeconomic terms-was marginal when compared to that which Atlantic slavery would have. 
Before the period of European colonial expansion, in very few regions throughout the old continent, the number of slaves exceeds $10 \%$ of the entire population. Rarely was the employment of slaves crucial in the development of European economy. In other words, keeping in mind the distinction drawn by Moses Finley, we could say that medieval Europe was a mosaic of state entities classifiable as slave-owning societies [5]. In most of these realities, as we said, the institution of slavery was present and tolerated but not totally socially accepted. It was considered as a practice originated and perpetuated by historical contingencies (conflicts, wars of religion, pillages and raids), but it was in opposition to natural law and morally deplorable. Several medieval legislative bodies defined slavery in these very terms. In this Code, inspired by Roman law [4, 6-8], the slave was defined as "res"-an object subject to the will of his master-but his condition was considered unjust, a transitional phase toward the regaining of freedom. Also for this reason, many laws dedicated to the discipline of slavery appeared as veiled with humanity and aimed to protect the slave from masterly abuse. A clear example in this sense is represented by the Siete partidas (1265) by Alfonso X, one of the most complete and extensive legislative recompilations conceived in the Middle Ages.

This concept of slavery was going to be completely transformed after the first phases of European expansion, between the fifteenth and sixteenth centuries, when Spain and Portugal crossed the columns of Hercules and began to colonize some islands in the Atlantic (Canary Islands, Madeira, São Tomé) [9-11]. The need to cultivate the conquered lands, together with the constant shortage of work force, made the recourse to slave labor almost indispensable. It was in these islands that the Atlantic plantation economy originated, an economic system that would be adopted by the majority of the European colonies in the New World.

The lucrative speculation arising from extensive agricultural colonization aroused the interest of nobles, bankers, investors, insurers, merchants and craftsmen, each of whom tried to carve out his own percentage of profit. Many invested in transport, others in the purchase of products to resale onto the European market, and some others began to invest in finding the element without which the whole system could hardly survive: the slaves. Within a few decades, the recruitment and exploitation of the slave labor force became a major political and economic question. The more the revenue from this activity increased, the more the number of plantations increased and, consequently, the demand for slaves that was necessary for cultivation. The enormous availability of latifundia in the Americas and the growing European demand for exotic products (sugar, cocoa, coffee, tobacco, indigo, etc.) did the rest. The Atlantic slave trade was in its germination phase, but its profit-oriented and inhuman logic was already a reality.

With the experience gained in Madeira, São Tomé and the Canary Islands, when the Europeans crossed the Atlantic Ocean and founded the first exploitation colonies in America, they were well aware that the land could be a source of income of great value, at least as much as gold, silver and gems. In fact, within a short time after their landing in the New World, the Spanish and the Portuguese attempted to replicate in their respective possessions the successful economic model experimented in the islands along the west coast of Africa. As a result, the number of slaves, first native and then African, in the Lusitanian and Spanish colonies grew steadily between the fifteenth and sixteenth centuries $[1,10,12,13]$.

Already during the sixteenth century, in the imperial territories of Spain and Portugal, there were areas where slaves represented the majority of the population. In these settlements, a small number of colonists had to control an increasing number of enslaved people. The numerical disparity between free and subjugated forced the former to use, more and more often, the iron fist to maintain the control of the colonies. In such circumstances, violence and abuse were becoming a daily 
occurrence. This worsened the life of the slave, which was already a very painful one. He worked from dawn to dusk, and his daily life was marked by the sound of the scudiscus, which sometimes cut the air and snapped on his fatigued limbs, tearing him apart in body and spirit. This was, in the opinion of the colonists, the most effective way to properly exploit their land and their investments. Such harsh conditions frequently forced the slaves to disobey their masters, by escaping or revolting and killing their harassers [14]. The fear of the slave revolts became, in a short time, a phobia with which the master class had to continuously live [15]. These kinds of situations were uncommon throughout the Old Continent. The rebellions, the runaways, and the heinous crimes committed by the slaves were rare events in modern Europe societies.

In order to regulate this system, which aims to the brutal exploitation of the labor force, the ancient laws on slavery-contemplated in the medieval codes-turned out to be totally inadequate. There was then the need for more stringent provisions to regulate a new type of slavery, which was now emerging in the Atlantic. It was therefore in such contingencies that the need for a special legislation for slaves became more and more evident: a codification conceived to discipline every aspect of their existence: life, death, marriage, religion, movements, food, clothing and all the procedures and practices for the regaining of freedom [16-18]. These normative bodies, also known as Black Codes, would not be adopted exclusively in the colonial possessions of the Iberian powers. Between the sixteenth and seventeenth centuries, when slave trade became a global phenomenon and several European states took part in the colonization of America and Africa, each of these states would promulgate its own slave codes.

\section{New slaves, new codes: slavery legislation in the Spanish and Portuguese empires}

The Spaniards and the Portuguese were the protagonists of the first phase of the colonization of the New World. When they arrived in America, they immediately realized the potential of the conquered lands. The resources seemed never to end: silver, gold, precious stones, immense latifundia. The native populations were subdued with relative easiness, being enslaved. However, the enslavement of the natives did not bring the desired results to the Europeans. Their frail constitution did not make them a workforce capable of satisfying the conquerors: thousands of them were employed in mines and plantations and soon died of hardship and fatigue. Moreover, the Indians were particularly susceptible to the diseases brought by the Europeans: the smallpox epidemics alone were responsible for several hundred thousand deaths among the natives $[12,19,20]$.

The high mortality rates among the Amerindians soon forced the colonists to look for an alternative workforce. The choice fell, after some initial hesitation, on the African slaves who had been employed with good results in the colonies that the Spanish and the Portuguese had created in the Canaries, Madeira and São Tomé.

In the Spanish Empire, the massive import of slaves from the Black Continent began in 1518, when Charles V granted the asiento de negro to the Flemish nobleman Laurent de Gouvenot and the Portuguese merchant Jorge de Portugal. As Elliot wrote, the signature of these contracts implied the definitive opening of the Spanish Empire to the Atlantic trade [21]. The possessions of the Spanish Crown were soon filled with African slaves. In his Historia de las Indias, Bartolomé de las Casas says that after the year 1520 in the West Indies, about 100,000 slaves landed from the African coast, 30,000 of which landed on the island of Santo Domingo [22]. Probably the number of the imported subjects was lower than the one indicated by the Dominican father [23], but their arrival had a significant impact on the Spanish 
colonial society and in particular on the Dominican one. The importation of African slave labor further worsened the already precarious living conditions on the island. Food rations became more scarce and violence perpetrated against slaves became more frequent. The mistreatment and harassment suffered by the latter would soon lead them to turn against their oppressors.

Between 1519 and 1521, there were several slave revolts on Santo Domingo [13, 15]. One of these occurred in the plantations owned by Viceroy Diego Colombo, the eldest son of the famous explorer, governor of the island. The slaves who rose on Christmas Day 1521 committed all sorts of heinous crimes, assaulting the owners' property and murdering "todos los cristianos que pudiesen" [24]. The rebels were almost immediately defeated and killed by the Spanish armies, but the ferocity with which they acted led Columbus to issue special regulations to control and discipline the black slaves who lived in the Dominican colony.

The ordinance that he promulgated on January 6, 1522, entitled Provisión del virrey Diego Colon [23], can be considered one of the first examples of Black Code in colonial America. In the provision, the governor paid attention to the behavior that the slave had to adopt in the public sphere, severely punishing the delinquent actions considered dangerous for the survival of the colony and especially the possession of weapons, rebellion, and the runaway of slaves. In order to prevent any further turmoil, through the ordinance the governor constituted a sort of colonial police force that had the responsibility of constantly monitoring the slave population. With the same aim of enhancing the effectiveness of the control and to maintain public order, the viceroy ruled that the slaves should no longer have the freedom to move within the colony: every movement of the slaves should be approved, with a special permit, by the master. Very harsh were the punishments imposed on the subjects who held weapons: depending on the degree of violation committed, slaves could be punished by public flogging. Equally severe were the punishments of the so-called cimarrones $[25,26]$, the slaves who ran away from their master: those who refused to return to work, within a maximum of 10 or 20 days, could also be sentenced to death by hanging ("incurra el dicho esclavo en pena de muerte, la cual le sea dada de horca") [23].

The Provisión can, in a certain sense, be considered the archetype of all the slave legislations that was promulgated between the sixteenth and eighteenth centuries in the Spanish colonies. Some of the principles contained in it (the prohibition to carry weapons, the ferocious persecution of cimarronaje, and the establishment of police forces to ensure the monitoring of slaves) were included in each of the subsequent codes. For example, Las Ordenanzas para la sujeción de los esclavos negros [27], issued by the Cabildo of Santo Domingo on October 12, 1528, and judged by Marcos Andrade Jaramillo the first black code in America [28], were nothing more than a careful revision and integration of what the Viceroy Provisión of 1522 had already established [15, 17, 18, 29-31].

The Ordenanzas issued on Santo Domingo constituted the legal basis of the great slave codes that appeared in Spanish America during the eighteenth century [32]. Among these, according to Manuel Lucena Salmoral, the most important were: the Ordenanzas dirigidas a establecer las más proporcionadas providencias así para ocurrir a la deserción de los negros esclavos como para la sujeción y asistencia de éstos, better known as Código de Santo Domingo (April 25, 1768) [33]; the Código de legislación para el gobierno moral, político y económico de los negros de la isla española, also known as Código Negro Carolino (December 14, 1784) [34]; and the Real Cédula Instrucción circular sobre la educación, trato y ocupaciones de los esclavos en todos sus dominios de Indias e islas Filipinas (May 31, 1789) [35]. Each of the above-mentioned codes, as Sala-Molins has well pointed out, were re-elaborations of the slave laws enacted in the Spanish colonies between the sixteenth and seventeenth centuries [32]. 
The eighteenth-century codes above mentioned, partly a result of Bourbon reformism [36], had the objective of drawing up a slave laws apparatus that would make it possible to improve the efficiency of the system of exploitation in the overseas colonies, imitating what had been done by another great colonizing power: France. The model was that of the French Black Codes promulgated in 1685 and 1724, which will be better discussed later. The eighteenth-century Iberian Codes tried to regulate slavery by making it "more human" and acceptable: the sovereignty of the master over the slave was largely limited and placed under the supervision of colonial and metropolitan governing bodies. The draconian punishments imparted to the slave were moderated, and some rights were granted to them (they had to be dressed, fed, and educated to the precepts of the Catholic religion and they could denounce any abuses suffered). The enactment of such measures provoked real upheavals in the colonial ruling classes: in the view of the slave owners, grant rights to the slaves could be very dangerous and could led to the destruction of the established system of exploitation, based essentially upon the abuse and social alienation of slave workforce [18, 20, 31, 37, 38].

An exception to this general trend is the Código de Luisiana (1769) [39], issued by the Spanish Governor Alejandro O'Reilly after the sale of the colony from France to Spain, which took place with the secret Treaty of Fontainebleau (1762). The text was essentially identical to the French Black Code issued in Louisiana in 1724. O'Reilly decided to adopt this code because it was considered more efficient than the Spanish one, in terms of perpetuation of the slave system born in the former French colony. During his mandate, the governor decided to include only few measures to implement the old code, one of which concerned the right granted to slaves to buy their freedom, the so-called derecho de coartación, which was not contemplated in the 1724 Code Noir [40-42]. This concession alarmed the colonial ruling class, which tried in every way to obtain the revocation of this privilege. The protests, raised by the owners of the plantations, led to a new reformulation of the slave legislation in the colony. In 1777, King Charles III, who was quite disappointed by the discontent of the slave masters, agreed that the laws on slavery should be rewritten. Hence, the King charged the Governor Bernardo de Gálvez to proceed with the drafting of a new code. Gálvez commissioned Francisco María de Reggio and Joseph Ducros, both high-ranking officials of the New Orleans Cabildo and owners of large plantations within the colony, to draw up the legislative body. After a few months of study and research, the two officials presented to the Cabildo a text entitled Code noir ou Loi municipale, servant de règlement pour le gouvernement \& l'administration de la justice, police, discipline \& le commerce des esclaves négres, dans la province de la Louisianne [43]. In this text, de Reggio and Ducros affirmed the need to leave all questions concerning the management of slaves to the will of the master. In order to protect the interests of the ruling class, the code legitimized all sorts of abuses and oppressions: the master could torture, humiliate and hunger his slaves without suffering any consequences in the courts of law. In other words, the master's will was above the law [44].

The precepts contained in the Code noir ou Loi municipale represented a fundamental legal source for all the other slave laws that were adopted in Louisiana between the eighteenth and nineteenth centuries. When this possession was acquired by the United States, in fact, the regulations of de Reggio and Ducros, together with the 1724 Code Noir, were the models for the first United States Black Codes issued in the colony [45]. Even in this, the ruling class had a sort of "absolute power" over the slave workforce.

The question of the master's sovereignty is an important element to keep in mind in order to understand the phenomenon of slave legislation in European colonial possessions. Even if in some cases the authorities tried to interfere with 
the authority of the dominus, to moderate the mistreatment and to make the slave's condition more acceptable, the master's will remains the only true code actually in force. Within his plantations, in his farms, the slave owner had no superior authority. The experience of slavery in the ultramarine empires was therefore, according to the contexts examined, even significantly harder than the one prescribed and contemplated by the law. Any slave owner, facing the possibility of losing his/her life or seeing his/her interests being severely damaged, would have no hesitation in violating or circumventing the existing laws. Although this fact was well known to colonial and metropolitan administrations, none of the states that took part in the colonial expansion renounced to the attempt to regulate the newborn overseas slave societies.

When the slave trade, between the sixteenth and seventeenth centuries, became a global phenomenon, almost all states with colonies in the New World adopted slave codes. Several of these were inspired by those already enacted in Spanish possessions during the sixteenth century. Portugal, for instance, during the period in which the Portuguese and Spanish crowns were united (1580-1640), adopted Spain laws into its own legislation [45].

The Ordenações Filipinas [46], promulgated by Philip I in 1603, were the most important demonstration of the process described above. This body of laws is the most organic and structured example of the slave code in force in Portuguese possessions until the nineteenth century. In Brazil, where the use of slave labor was fundamental for the maintenance of the colony, the code remained in force until 1822, when the Brazilian possession gained independence from the mother country. Even after independence, many of the precepts contained in the Philippine corpus continued to represent the legal basis for regulating the relations between slave and master within the country, at least until 1888, when the slave system was definitively abolished $[46,47]$.

The principles on slavery stated in the Philippine ordinances were very similar to those contained in the Spanish Codes issued between the sixteenth and seventeenth centuries: there were numerous articles aiming at sanctioning the prohibition of the possession of weapons, the restrictions on freedom of movement and, more generally, the absolute social alienation of the slave. In exchange of the full control on his own workforce, the Philippine ordinances required from the master a certain moderation in his behavior: he should not punish the slave in an unmotivated way, and he should not either torture or physically abuse him. Even if in the Code the slave was not considered as a human being but as a good, and as such had to be inventoried, the Ordenações Filipinas tried to preserve his safety, by limiting the violence that he was often forced to suffer. Such conduct may perhaps have been useful in avoiding the outbreak of riots and unrest, but it was more likely to be conceived as a way to impose a limit on the sovereignty of the ruling class: through the law the state and its organs had to supervise and stop episodes of uncontrolled violence.

These attempts to delimit the power of the masters had very little impact on overseas slave societies. As Batista and Zaffaroni wrote, reflecting on the Brazilian colonial reality, at a local level, there was a sort of "poder punitivo doméstico" $[48,49]$, essentially based upon the master's arbitrariness. Batista and Zaffaroni's consideration can be judged suitable not only for Brazil but also for all Lusitanian domains and, more generally, for all European ultramarine possessions where an economic system based upon the exploitation of slavery was created.

This failure to delimit the master's arbitrariness had repercussions on the real effectiveness of the slave laws, which were-according to necessity-ignored, reinterpreted or deceived. For this reason, for example, the authorities-both metropolitan and colonial-were often forced to reaffirm, remodel and strengthen through specific measures some precepts that had already been widely stated in the 
issued Codes. Regarding the Portuguese colonial experience, this operation was carried out through the so-called Legislação Extravagante, that is, series of ordinances, provisions and decrees enacted in order to intervene on particular issues that arose in a particular possession $[46,50,51]$.

The provisions on slavery contained in the Legislação Extravagante tried to intervene on the most disparate aspects of the slave's life: from his treatment to his nourishment, from his transport to his employment within the colonial realities. Reading these ordinances, it is easy to understand how almost all the royal laws or provisions, promulgated with the intention of restraining abuse, did not find any acceptance in the daily life of colonial life. Merely as an example, we can mention the royal provisions issued by Afonso VI (September 23, 1664) [52] and Pedro II (March 18, 1684) [53] in order to regulate the transport of slaves taken from the African coasts. In these documents, attention was paid to the measures to be taken in order to ensure that navigation was not fatal for the slaves on board; in particular, the sovereigns established the minimum quantities of water and food that should be available on the slave ships in order to avoid the numerous deaths-due to hunger and dehydration - that sadly characterized the so-called middle passage. The royal prescriptions, as already mentioned, had a very modest impact on what were the behaviors of the Portuguese slave traders. Indeed, between the seventeenth and eighteenth centuries, due to the growing demand for workforce from the New World, the number of slaves deported increased significantly and the conditions in which they were transported worsened. Despite the provisions, it rarely happened that more than two-thirds of the slaves loaded on the slave ships could see the colony of destination. Many of these deaths, recorded during the crossing, continued to be attributable to a lack of water $[54,55]$.

What was said about the measures concerning the slave trade and transport can be extended to any other aspect that the slave legislation tried to regulate. Although the Philippine ordinances and the instructions given through the Legislação Extravagante categorically prohibited harassment and abuse, even in the nineteenth century (in the wake of the abolitionist era), the colonial ruling class continued to torture, mutilate, brand and whip its slaves even for apparently futile reasons, acting in total impunity [56].

\section{The slave codes in British and French ultramarine possessions}

Also other states that were involved in the colonization adopted, as anticipated, special codes for slavery. At first, this need became particularly urgent in the Caribbean colonies owned by England and France, where the sugar revolutionwhich took place in the mid-seventeenth century-brought a significant increase of the number of slaves deported in these domains [18, 57-59].

Regarding the British colonial experience, the creation of a large system of sugarcane plantations proved to be crucial for the emanation of the first exemplars of Black Codes [57]. The circumstances in which English colonial authorities enacted the Act for the better ordering and governing of Negroes (1661) [60, 61], better known in historiography as Barbadian Code or Barbados Slave Code, are indicative in this sense.

When the colonization of Barbados began in the second decade of the seventeenth century, the economic system of the estate was based upon the cultivation and commercialization of tobacco, trying to emulate the economic model born in Virginia. In these early stages, the core of the workforce on the island was made up of indentured workers who were mainly recruited from the mother country [61]. However, this plan of development failed to produce the expected results. 
The tobacco produced in Barbados could not compete in price and quality with the abundant Virginian production that already at the end of the 1630s had exhausted the demand of the London markets.

In these conditions, a large part of the plantations on the Caribbean island were then converted to cotton and indigo but without obtaining better results [62]. In order to overcome a growing economic recession, several landowners in Barbados then decided to experiment the extensive culture of sugarcane. As the cultivation of sugarcane spread over the island, white workers were more frequently replaced by African slaves, considered more suitable to support the hard work necessary to exploit the "white gold" plantations. The censuses of Barbados in the 1650 s were the last in which the white population was larger than the black population. Between 1652 and 1661, when the number of black slaves grew significantly within the colony, the African subjugates began to be perceived as a threat by the governing bodies of the island: because of the harsh conditions in which they lived, riots and disorders were feared. The creation of special rules for slavery, designed with the aim of maintaining public order in the colony, became a necessity at this point [61]. It was for these reasons that the Barbadian Code was created [63]. In the preamble of the Code, this latter need was clearly expressed by the legislators.

The authors of the legislative body pointed out that the various colonial governments that followed over the years had produced some good laws on slavery, but these regulations proved to be incomplete and incapable to deal with the new social conditions of the island. The ancient laws could not be applied to Atlantic slavery.

Like the other states that have been mentioned until now, England, at the time of the establishment of its ultramarine possessions, did not have a legal tradition in slave legislation. Notwithstanding this, the English who established in the first Atlantic colonies had within their legal background some jurisprudential categories that allowed them to organize the slave institution. Among these categories was the principle of absolute property. According to the Common Law, for the English colonizers, the slave was, to all intents and purposes, a patrimonial property and therefore could be used by their master as he or she wished [64-66].

The classification of the slave as a patrimonial good was in fact sanctioned in the first lines of the preamble of the Barbadian Code together with the desire to protect, as property, the work force from any violence committed by its owners ("protect them as we do many other goods and chattels") [61]. Beyond the statements in the prolog, the Barbadian Code was a very rigorous slave code, which was not intended to protect slave labor. It focused, instead, on the punishment of the slaves, considered as a threat for the safety of the white population of the island. Reading the articles of the Code emerges that the British colonists considered the Africans as barbaric people ("brutish") [61]. "The barbarism of Africans"-as Rugemer stated-“precluded them from the possession of rights as the English understood them. Unlike contemporaneous Spanish American and Brazilian legislation based on the medieval Siete Partidas, or the French Code Noir that would follow in 1680, the 1661 Slave Act did not attribute any positive rights to slaves whatsoever" [64].

In short, the regulation of 1661 sanctioned almost all the prohibitions already present in the slave legislation discussed until now (prohibition to carry weapons, restrictions regarding the freedom of movement, etc.). However, unlike many of the slave codes promulgated by the other European powers, it did not provide any measure for the possible integration of the subjects within the society. There was a lack of clear regulations on slave liberation and religious life. With the exception of the master's obligation to provide clothing to the slaves at least once a year, some of the fundamental rights of the slave that were recognized, at least formally, in the Spanish Ordenanzas and, as we will see, in the 1685 French Code Noir were not enshrined in the 1661 text: that is to say, the right to be freed and to be fed. 
What emerged from the articles of the Barbadian Code was, in conclusion, a system of regulation of slavery designed to control the entire workforce, built on the conviction that primitives and barbarian Africans were naturally destined to be slaves because of their inferiority from a cultural and racial point of view.

The political and economic model established on Barbados was very successful, and the profits made from the sugar trade during the seventeenth century were enormous [67]. In part, this exploit was attributed to the effectiveness of the slave legislation in force on the island $[65,66]$. As a result, the Barbadian Code was rapidly exported both to the other colonies owned by the British in the Caribbean and to those located in North America. The principles in this statute, a bit like the provision of Columbus in the Spanish domains, will be a fundamental reference for every slave code born in the colonies of England and in the United States [65, 68, 69].

More than 20 years after the promulgation of the Barbadian Code, one of the best-known and most studied slave codes, the so-called Code noir Louis was issued in France (1685) [70]. The legislative body was drawn up at the behest of King Louis XIV and Jean-Baptiste Colbert, minister of the King of France and strong supporter of the importance of the colonies as an economic resource for continental France. In order to fully exploit the potentialities of the conquered territories, both the sovereign and the minister considered it fundamental to rationalize the employment of the slave workforce. That rationalization was crucial to support the economic system of some of the richest and most productive colonies of the French Empire. The creation of a regulation that intervened in an exhaustive way on these aspects became soon a diriment political issue $[16,70,71]$. The complex and articulated slave code issued in 1685 was the result of this no longer delayable necessity. Its 60 articles examined in depth all practical aspects of the slave's life within the colonies: from religion to marriage, from concubinage to imprisonment, from crimes to corporal punishment and pecuniary sanctions, and even the ways in which the slave achieved freedom.

Most of its provisions focused, as in the other examples of slave codes already mentioned, on questions of public order. To ensure security, the Louis regulation roughly imposed the well-known bans on the possession of weapons and on freedom of movement, which had already been widely discussed. Although punishments and deprivations are a fundamental part of the legislative body, this seems to open-more than other previous and contemporary exemplars-to the integration of African slaves in the French colonial society. The baptism and conversion of slaves to Catholicism, their participation in religious celebrations and their abstention from work on feast days were all measures conceived, maybe, with the intention of building a more cohesive and less conflictual colonial community.

One of the most innovative aspects of the Code was undoubtedly the various regulations protecting the slave workforce. The legislator seemed to have a clear idea of the poor condition in which the slaves lived: submitted to the master's will, they could be killed, tortured or left to die of hunger and thirst. Being aware of what was happening in the colonies, the editors of the Edict tried to impose a limit on the authority of the masters, by placing it under the control of the state. For the Code, slaves were movable good, an extension of the legal personality of its owner, but the supreme government over them was a prerogative of the state authority.

The Louis regulations also contain provisions obliging the master to provide food and clothing for his slave workforce. By imposing such obligation, the legislators believed to reduce the percentage of slaves who die for hunger or who escape because of the lack of supplies.

Many of the measures enshrined in the 1685 Code Noir, like that issued in other slave code already mentioned, remained almost a dead letter. The paternalistic view of slavery that characterized several of its dispositions never rooted in French 
ultramarine possessions. The concessions made by the Code to slaves were considered by the ruling class to be too damaging for their own interests.

The reasons behind the non-application of many of the precepts contained in the Edict were not only economic. There were also racial prejudices: the conviction that blacks were inferior to whites was quite widespread in the colonies. There is no law that had the power to change that belief [72]. Hence, despite the expressed prohibition imposed by the royal legislation, the slaves continued to be mutilated, massacred, killed or left to starve. Their lives in the colonies continued for many decades to be marked by abuse and masterly arbitrariness, most frequently in the substantial indifference of the authorities. This situation will not change in a tangible way until the great revolution of Haiti $[73,74]$.

Despite resistance displayed by the ruling class and its limited application, the Code was nevertheless a fundamental model for all the French slave legislation enacted between the seventeenth and eighteenth centuries. Although it was created to regulate slavery in the Caribbean possessions of France, the Code noir Louis became the main legal reference in the field of slavery also in other French domains, in North America (Louisiana) and in Africa (Mascarene), where the plantation economy was experimented. In these colonies, the precepts of the regulation issued in 1685 continued to exert their influence even when specific legislative bodies were promulgated for each of these colonial realities. The Codes issued in Louisiana (1724) and in the Mascarene Islands (1723) were, in fact, nothing more than a revision, or rather an adaptation to the characteristics of each colony, of the famous Code Noir promulgated at the end of the seventeenth century [75].

\section{The slave codes in Denmark and Sweden}

When the colonization process undertaken by European states was on the edge and involved a great number of actors, it was a common belief that adopting special slave codes would help to have more control over possessions, avoiding revolts in them. The prescriptions of the Codes, in the eyes of the colonial administrators, were useful to reduce the conflict between the slaves and the masters. At the same time, slave laws linked the slave to his condition of slavery almost in an inextricable way.

These provisions aimed to preserve public order, and therefore the system of exploitation built by the colonists, not only by disposing the deprivations of the liberties of enslaved individuals but also by justifying these deprivations on the pretext of the ethnic and cultural inferiority of the slaves. The clear purpose of the Codes was to protect small white communities from possible assaults by black multitudes. However, in order to do this, it was not enough to prohibit the use of weapons, but it was necessary to instill the principle of superiority of the white race. The whites were to be considered by Africans as untouchable individuals whose bodies and physical integrity could not be violated by a black hand. For this reason, in many Codes, even the intention to strike a white man could be punished severely. For the same reason, unions or marriages between whites and blacks, when not expressly forbidden, were seen as a contamination, a sort of perversion of the natural order of things [75].

The provisions concerning the physical protection of whites were often accompanied by precepts that tended to discourage or prohibit manifestations of the slave culture. Religious rites, dances and African customs were considered dangerous in the Codes, because they could upset white people and be a bond between the ranks of slaves present in the colonies. The subjugated could not have their own culture because it constituted a manifestation of human nature and the slaves were not 
considered men. Their role was to work, to serve the master and to submissively follow his orders. He existed in function of his master and for nothing else.

These were the key concepts that were laid down in all the major slave codes issued in the overseas colonies during the seventeenth century. These legal precepts were considered as the substratum necessary to ensure the functioning of an exploitation colony. Whatever was the size of its slave population, a slave society had to have laws that specifically dealt with slavery. This may help to understand why the instrument of the slave code was adopted even in small realities and by states that played a very marginal role in the process of colonization of the Americas.

Denmark, for example, after taking possession of the Virgin Islands (between the end of the seventeenth century and the beginning of the eighteenth), adopted the so-called Gardelin Code (1733) in its colonies. The legal text, named after its editor-Philip Gardelin, governor of the island of Saint-Thomas-was one of the most rigid slave codes in the European colonial panorama [76]. With its adoption, the Danish administrators hoped to keep under control the huge mass of slaves employed in the sugarcane plantations born in their domains. However, as the slave revolt on Saint-John (1733) demonstrated, deprivation and oppression were not always a valid solution to the problems of public order within the colonies.

Sweden too, in the colony of Saint-Barthélemy-bought by the French at the end of the eighteenth century in exchange of some commercial privileges in the port of Gothenburg-adopted its own slave code: the Code von Rosenstein (1787). Like the Danish one, the Swedish text was thus named because of its editor, Pehr Herman Von Rosenstein, governor of the island from 1787 to 1790 [76]. It was a code inspired by French slave legislation, in particular by an ordinance on the treatment of slaves issued in Martinique in 1783. The legislative body was a kind of summary in which the tradition of European Slave laws was collected. In the norms established by Rosenstein, the African slaves were considered as treacherous and evil, not deserving to be considered human. They were not allowed to gather, to profess their beliefs, or even to ride a horse. The normative text configured itself as an instrument for the control of the entire black population: in fact, numerous articles were dedicated exclusively to the regulation of the life of the freed slaves. It was in this regard that we noted the only real innovation of the von Rosenstein Code compared to the French legislation to which, as we said, it is inspired.

\section{Conclusions}

The political and economic reasons that led to the creation of the slave codes are very clear. They were considered necessary to maintain public order in the colonies, avoiding the outbreak of riots and thus allowing the slave exploitation system to function more efficiently. In order to achieve these objectives, the codes could provide both strictly punitive rules, designed to create terror in the slave labor force, and paternalistic rules, designed to make the bitter life of the slave more bearable. The last-mentioned rules, however, should not be understood as a partial recognition of the slave's rights: they represented only concessions made in order to prevent the inevitable outbreak of riots and unrest. In fact, very few masters were tried for breaking the rules laid down in the codes: the mistreatment and abuse committed against slaves remained a constant and the authorities did not show a marked perseverance in prosecuting these crimes. This indicates that, apart from formal recognition, the rights granted to slaves, except in rare cases, remained a political expedient rather than a reality. The aforementioned helps to understand why in the colonial daily life many of the prescriptions contained in the codes remained substantially inapplicable. The ruling class often judged the norms of the 
codes to be too permissive and paternalistic: they appreciated their punitive and persecutory measures, circumventing most of the laws that attempted to limit their sovereignty. Analyzing all these elements, it seems evident that the impact of slave codification on the administration of slave workforce was relatively marginal: the will of the master remained the only true law to which slaves should have obeyed. No law, in fact, would have succeeded in undermining, containing or reducing the master's sovereignty. But the codes were not only a political instrument but also a cultural product of the slave society and are important because by studying them it is possible to analyze the characteristics of the discriminatory and segregationist system constituted in the European colonies of exploitation. One of the fundamental tasks of the codes was to try to eternalize the existing slave system, not only from an administrative and legal point of view but also from a cultural and moral point of view. It was above all in this latter perspective that the impact of the codes was significant: not only did the slave codes try to discipline the many aspects of the life of the slaves in the colonies but also contributed to further dehumanizing the African workforce. The whips, the mutilations and the draconian punitions contributed to invalidating in some way all the regulatory instruments that the same codes provided for the slave's protection. Slaves had no human dignity according to the law and therefore, in the eyes of the landowner class-who was already not very disposed to tolerate external intrusions - they did not deserve to be safeguarded.

While the application of the codes was therefore sporadic and arbitrary, much more important was the cultural impact that the slavery laws had on the societies in which they were adopted. This impact conditioned the perception of the slave institution and became the foundation of the European exploitation colonies. The idea of slave as a factor of production, as an object, is deeply rooted in all the societies that adopted slave legislation. That is why the idea of the slave (and the African slave in particular) as an inferior human being resisted even after slavery was abolished. From this point of view, the slave legislation has certainly achieved one of the objectives it aimed to pursue: the perpetuation of the economic and cultural patterns that lie behind the slave system.

\section{Author details}

Giuseppe Patisso* and Fausto Ermete Carbone

Università del Salento, Lecce, Italy

*Address all correspondence to: giuseppe.patisso@unisalento.it

IntechOpen

(C) 2020 The Author(s). Licensee IntechOpen. This chapter is distributed under the terms of the Creative Commons Attribution License (http://creativecommons.org/licenses/ by/3.0), which permits unrestricted use, distribution, and reproduction in any medium, provided the original work is properly cited. (cc) BY 


\section{References}

[1] Solow BL. Capitalism and slavery in the exceedingly long run. The Journal of Interdisciplinary History. 1987;17(4):711-737

[2] Verlinden C. L'esclavage dans

l'Europe médiévale. Vol. 119. Bruges: De Tempel; 1955

[3] Verlinden C. L'esclavage dans l'europe médiévale. 2. Italie-Colonies italiennes du Levant; Levant latin-Empire byzantin. Gent: Rijksuniversiteit; 1977

[4] Rotman Y. Les esclaves et l'esclavage: De la Méditerranée antique à la Méditerranée médiévale. París, Les Belles Lettres: VIe-XIe siècles; 2004

[5] Finley MI, Shaw BD. Ancient Slavery and Modern Ideology. London: Chatto \& Windus; 1980

[6] Fiume G. La schiavitù mediterranea tra medioevo e età moderna. Una proposta bibliografica. ESTUDIS. 2015;41:267-318

[7] Phillips WD. Slavery from Roman Times to the Early Transatlantic Trade. Manchester: Manchester University Press; 1985. p. 312

[8] Inikori JE. Slaves or serfs? A comparative study of slavery and serfdom in Europe and Africa. In: Okpewho I et al., editors. The African Diaspora: African Origins and New World Identities. Bloomington, Indianapolis: Indiana University Press; 2001:49-75

[9] Phillips WD Jr. Slavery in the Atlantic Islands and the Early Modern Spanish Atlantic World. The Cambridge World History of Slavery Vol III: AD 1420-AD 18042011. pp. 325-349

[10] Greenfield SM. Madeira and the beginnings of new world sugar culti and plantation slavery: A study in institution building. Annals of the New York Academy of Sciences. 1977;292(1):536-552

[11] Higginbottom A. Enslaved African Labour in the Americas: From primitive accumulation to manufacture with racial violence. Revista de Estudos e Pesquisas sobre as Américas. 2018;12(1):22-46

[12] Stone EW. America's first slave revolt: Indians and African slaves in Española, 1500-1534. Ethnohistory. 2013;60(2):195-217

[13] Patisso G. Schiavitù nera e legislazione schiavista nella prima fase di colonizzazione di la Espanola: La provisión del viceré Diego Colombo (6 gennaio 1522). Mediterrán

Tanulmányok, Études sur la Région Méditerranéenne. 2017;26:5-25

[14] Elliott JH. The Hispanic World: Civilization and Empire, Europe and the Americas, Past and Present. New York: Harry N Abrams Inc; 1991

[15] Patisso G. Droit des Esclaves - I Codici neri del 1685 e del 1724 nei Territori della Nuova Francia. Giornale di Storia Costituzionale. 2007;14:43

[16] Patisso G. Dall'asiento ai codes noirs: I tentativi di normativizzazione della schiavitù (sec. XV-XVIII). Eunomia Rivista Semestrale di Storia e Politica Internazionali. 2012;1(1):65-84

[17] Patisso G. Las amargas reglas del azúcar. Legislación esclavista francesa y española en la América Colonial. Dialéctica Libertadora. 2015;0(7):143-156

[18] Bacci ML. Conquista: La distruzione degli indios americani. Il Mulino: Bologna; 2005

[19] Mateo VM, Vivas FJM. La esclavitud en Hispanoamérica: Consecuencias en 
el desarrollo económico de las colonias españolas en el Nuevo Mundo. Isla de Arriarán: Revista Cultural y Científica. 2000;16:141-164

[20] Elliot JH. Empires of the Atlantic World: Britain and Spain, 1492-1830. New Haven, Conn.: Yale University Press; 2006

[21] Casas BDL. Historia De Las Indias Tomo III - Edicion, prologo, notas y cronologia Andre Saint-Lu. Volumen 110 De La Coleccion. 1st ed. Caracas: Biblioteca Ayacucho; 1986

[22] Dipp HT. Raza e historia en Santo Domingo. Santo Domingo: Editora de la Universidad Autónoma de Santo Domingo; 1974. p. 252

[23] Colon D. Provisión del virrey Diego Colon, 6 de enero de 1522.agi, Patronato, 295, 92, 104

[24] Arrom JJ. Cimarrón: Apuntes sobre sus primeras documentaciones y su probable origen. Revista Española de Antropología Americana. 1986;13:15-30

[25] Andrade M. La legislación afrocolonial en el Caribe (siglos XVIXVIII). In: 49 Congreso Internacional de Americanistas. Quito. 1997

[26] Salmoral ML. Regulación de la esclavitud negra en las colonias de América española (1503-1886): Documentos para su estudio. Vol. 6. Editum; 2005

[27] Deive CE. Los guerrilleros negros: Esclavos fugitivos y cimarrones en Santo Domingo. Fundacion cultural dominicana; 1989

[28] Domingo CS. Las Ordenanzas para la sujeción de los esclavos negros. 12 octubre1528. agi, Estado, 7, 3, ff. 26-45

[29] Peñuela CG-G. Sobre el ordenamiento jurídico de la esclavitud en las Indias españolas. Anuario de Historia del Derecho Español. 1980;50:1005-1038

[30] Lucena SM. Los códigos negros de la América española. Alcalá: Universidad de Alcalá; 1996. p. 75

[31] Molins LS. L’Afrique aux Amériques: Le Code Noir espagnol. Paris: Presses Universitaires de France-PUF; 1992. p. 200

[32] Domingo CS. Ordenanzas dirigidas a establecer las más proporcionadas providencias así para ocurrir a la deserción de los negros esclavos como para la sujeción y asistencia de éstos. AGI; 1768:1034

[33] Código de legislación para el gobierno moral, político y económico de los negros de la Isla Española. Santo Domingo: AGI; 1784. p. 1034

[34] Real Cédula Instrucción circular sobre la educación, trato y ocupaciones de los esclavos en todos sus dominios de Indias e islas Filipinas. Biblioteca Nacional (Madrid); 1789. Manuscritos, 8834, ff. $1-8 \mathrm{v}$

[35] Postigo JLB. Las dos caras de una misma moneda. Reformismo y esclavitud en Santo Domingo a fines del periodo colonial. Revista de Indias. 2014;74(261):453-482

[36] Maldonado MEC. Paternalismo, iluminismo y libertad. La vigencia de la Instrucción esclavista de 1789 y su impacto en la sociedad colonial. Historia y Sociedad. 2011;21:61-93

[37] Bando del Gobernador de Luisiana O'Reilly sobre aplicación del Código Negro para el comercio de esclavos en la Colonia. Biblioteca Nacional (Madrid), Inventario General de Manuscritos, Manuscritos de Amèrica; 1769. 19246, 24

[38] Baade HW. The Gens De Couleur of Louisiana: Comparative slave law 
in microcosm. Cardozo Law Review. 1997; 18:535

[39] Lucena Salmoral M. La instrucción sobre educación, trato y ocupaciones de los esclavos de 1789: Una prueba del poder de los amos de esclavos frente a la debilidad de la corona española. 1996

[40] Din GC. Spaniards, Planters, and Slaves: The Spanish Regulation of Slavery in Louisiana, 1763-1803. 1st ed. College Station: Texas A\&M University Press; 1999

[41] Gross AJ. Legal Transplants: Slavery and the Civil Law in Louisiana. Report No.: ID 1403422. Rochester, NY; 2009

[42] Code noir ou Loi municipale:

Servant de reglement pour le gouvernement \& l'administration de la justice, police, discipline $\&$ le commerce des esclaves négres, dans la province de la Louisianne : Entreprit par délidération [sic] du Cabildo en vertu des ordres du Roi, que Dieu garde, consignés dans sa lettre faite à Arnjuez le 14 de mai 1777. A la Nlle. Orléans: De l'imprimerie d'Antoine Boudousquié imprimeur du Roi, \& du Cabildo; 1778

[43] Ingersoll TN. Slave codes and judicial practice in New Orleans, 1718-1807. Law and History Review. 1995;13(1):23-62

[44] Territory of Orleans. Acts passed at the first session of the first Legislature of the Territory of Orleans: Begun and held in the City of New Orleans, on the 25 th day of January, in the year of our Lord one thousand eight hundred and six, and of the independence of the United States of America the thirtieth. New Orleans: Bradford \& Anderson, Printers to the Territory; 1807. x, p. 221 (Binder's title: Louisiana, Territory of Orleans)

[45] Lara SH. Legislação sobre escravos africanos na América portuguesa. Madrid: Fundación Histórica Tavera/
Digibis/Fundación Hernando de Larramendi; 2000

[46] Portugal. Código filipino, ou, ordenações e leis, do Reino de Portugal: Recompiladas por mandado d'el-rey d. filipe I. Brasília: Senado Federal, Conselho Editorial; 2004

[47] Peabody S, Grinberg K. Slavery, Freedom, and the Law in the Atlantic World: A Brief History with Documents. Boston: Bedford/St. Martins; 2007

[48] Batista N, Zafaronni RC. Direito Penal Brasileiro. Vol. I. Rio de Janeiro: Revan; 2004

[49] da Silva FR. Linhas de força da legislação ultramarina portuguesa no século XVII (1640-1699). Revista de Ciências Históricas. 1991;6:187-210

[50] Wehling A, Wehling MJ. O escravo na justiça do Antigo Regime: O Tribunal da Relação do Rio de Janeiro. ARQUIPÉLAGO-Revista da Universidade dos Açores. 1999;3:119-137

[51] de Andrade Silva J. Provisão de 23 de setembro de 1664, Collecção chronologica da legislação portuguesa. Lisboa: Impr. de J.J.A. Silva. p. 1854

[52] de Andrade Silva J. Provisão de 18 de março de 1684. In: Collecção Chronologica da Legislação Portuguesa. Lisboa: Impr. de J.J.A. Silva. p. 1854

[53] Osório I. Políticas régias sobre o tráfico de escravos: Análise da legislação produzida entre 1640 e 1706. In: Machado A et al., editors. Omni Tempore. Encontros da Primavera 20142015. Porto: Universidade do Porto, Faculdade de Letras, Biblioteca Digital; 2017:287-322

[54] Eltis D, Richardson D. Routes to Slavery: Direction, Ethnicity and Mortality in the Transatlantic Slave Trade. London, New York: Routledge; 2013 
[55] Martins RB. A obsessão com o tráfico, a legislação escravista e os códigos negreiros portugueses. In: Niterói: Associação brasileira de pesquisadores em história econômica. 2017. pp. $1-21$

[56] Sheridan RB. Sugar and Slavery: An Economic History of the British West Indies, 1623-1775. Barbados, Jamaica, Trinidad and Tobago: Canoe Press; 1994. p. 558

[57] Knight FW. The Caribbean sugar industry and slavery. Hagelberg GB, Kiple KF, Fraginals MM, editors. Latin American Research Review. 1983;18(2):219-229

[58] Higman BW. The sugar revolution. The Economic History Review. 2000;53(2):213-236

[59] Menard RR. Sweet Negotiations: Sugar, Slavery, and Plantation Agriculture in Early Barbados. Charlottesville: University of Virginia Press; 2006. p. 220

[60] An Act for the better ordering and governing of Negroes. 1661

[61] Gragg LD, Gragg P. Englishmen Transplanted: The English Colonization of Barbados, 1627-1660. Oxford: Oxford University Press; 2003. p. 254

[62] Beckles HMD, Downes A. The economics of transition to the Black labor system in Barbados, 1630-1680. The Journal of Interdisciplinary History. 1987;18(2):225-247

[63] Rugemer EB. The development of mastery and race in the comprehensive slave codes of the greater Caribbean during the seventeenth century. The William and Mary Quarterly. 2013;70(3):429-458

[64] Tomlins C. Transplants and timing: Passages in the creation of an Anglo-American law of slavery. Theoretical Inquiries in Law. 2009;10(2):389-421

[65] Nicholson BJ. Legal borrowing and the origins of slave law in the British colonies. American Journal of Legal History. 1994;38:38-54

[66] Dunn RS. The English Sugar Islands and the founding of South Carolina. The South Carolina Historical Magazine. 2000;101(2):142-154

[67] Tomlins C. Freedom Bound: Law, Labor, and Civic Identity in Colonizing English America, 1580-1865. Cambridge: Cambridge University Press; 2010. p. 641

[68] Debe DD, Menard RR. The transition to African slavery in Maryland: A note on the Barbados connection. Slavery \& Abolition. 2011;32(1):129-141

[69] Édit du roi ou Code Noir réglementant le statut des esclaves dans les îles Françaises d'Amérique mars 1685. FR ANOM, COL, Série B 11, 129

[70] Palmer V. Essai sur les origines et les auteurs du Code Noir. Revue Internationale de Droit Comparé. 1998;50-51:111-140

[71] Niort J-F. Le problème de l'humanité de l'esclave dans le Code Noir de 1685 et la législation postérieure: Pour une approche nouvelle. Cahiers aixois d'histoire des droits de l'outre-mer français (PUAM). 2008; (4):1-29

[72] Rogers D. Sguardi divergenti sull'assimilazione dei liberi di colore negli archivi del siniscalcato del Petit-Goâve, parte francese di Santo Domingo (1778-1786). QS. 2015;(1/2015)

[73] Ghachem MW. Prosecuting torture: The strategic ethics of slavery in pre-revolutionary saint-Domingue 
Slavery and Slave Codes in Overseas Empires

DOI: $h t t p: / / d x$.doi.org/10.5772/intechopen.91411

(Haiti). Law and History Review.

2011;29(4):985-1029

[74] Patisso G. Codici neri. Carocci:

Roma; 2019

[75] Patisso G. Gli schiavi della Croce bianca. Colonizzazione, legislazione repressiva e rivolte nelle Indie Occidentali danesi (1663-1733). Studi Storici: Rivista Trimestrale dell'Istituto Gramsci. 2017;58(2):369-400

[76] Patisso G. Gli svedesi a SaintBarthélemy tra economia schiavista e Codice nero von Rosenstein (sec. XVIII-XIX). Studi Storici: Rivista Trimestrale dell'Istituto Gramsci. 2016;57(2):361-388 



\title{
Chapter 5
}

\section{Traffickers: Are They Business People, Psychopaths or Both?}

\author{
Jennifer Okeke, Mel Duffy and Rosaleen McElvaney
}

\begin{abstract}
Human trafficking has become a very contentious issue, constituting one of the most grievous human rights violations and most lucrative activities for criminal gangs and individuals. The selling and buying of human beings as a commodity has become so profitable and the industry so big that armed groups and terrorist organisations are turning to trafficking in people as a source of income to fund their organisations. Traffickers motivated by profit take advantage of vulnerable individuals, ignoring the consequences of their actions on those lives. The trafficker's apparent lack of empathy or guilt and the ability to shut the self off from the impact of their actions is not unlike some of the noted characteristics of a psychopath. This chapter reviews published literature on trafficking and discusses whether there are psychopathic tendencies among traffickers or if they are primarily motivated by profit alone.
\end{abstract}

Keywords: traffickers, victims, human trafficking, profit, psychopaths

\section{Introduction}

Trafficking in persons is a grave violation of human rights that affects every country in the world [1] It is a serious crime with significantly higher numbers of victims than are represented in official data and involves the buying and selling of girls, women, boys and men for economic gain with harmful costs for the individuals, the economy and society [2]. Measuring human trafficking is challenging. Progress has been made in the collection and provision of information on the characteristics of the victims. A further challenge is gaining an adequate understanding of the traffickers. This is essential given the increasing numbers of traffickers entering into the business [3]. Traffickers are sometimes written off, rather simplistically, as psychopaths [4], yet our increased knowledge of the business of trafficking, in particular, the profitability of such a business, suggests a more complex picture. This chapter explores the economics of the business of trafficking in human beings, by looking at recent statistics on prevalence of trafficking, the rewards that some have argued is the primary motivational factor for individuals and organisations and the place of the traffickers in the demand and supply chain. The chapter also explores the profile of the traffickers and the commonalities highlighted in the literature between traffickers and psychopaths, raising the question as to whether trafficking is motivated by profit or a consequence of psychopathic behaviour. Research in this area is limited, and it is difficult to reach clear conclusions, given the diversity inherent in trafficking and those who traffic. However, given the significant impact of trafficking on individuals who have been trafficked, their 
families and wider society, an understanding of traffickers is important to include in efforts to prevent this crime in the future.

\section{Prevalence of trafficking}

Modern-day slavery continues to grow and enslave people around the world. Human trafficking involves various forms of exploitation which can be widespread in different sectors [5] The International Labour Organisation (ILO) has, since 2005, classified forced labour into three main categories: (1) forced labour imposed by the state, which includes every type of job exacted by public authorities, paramilitary or military organisations, forced prison labour and mandatory participation in general work; (2) forced labour imposed by private agents for sexual exploitation, including all types of sexual activities; and (3) forced labour imposed by private agents for labour exploitation, covering forced domestic labour, bonded labour, forced labour of migrants in various economic sectors and forced begging for gangs [6]. As of 2014, over 21 million men, women and children were estimated to be trapped in forced labour, debt bondage, trafficking or working in a slave-like state [7]. By 2016, an estimated 40.3 million people were described as trapped in modern-day slavery, implying that on any given day there were an estimated 40 million people forced to work against their will or to live in a forced marriage, with girls and women disproportionately affected [8]. This report revealed that women and girls constituted $99 \%$ of victims of forced labour for commercial sex, 58\% in other forms of exploitation and in the past 5 years, some form of modern-day slavery had been experienced by an estimated 89 million people.

Despite the improved and updated methods being used to estimate the number of those trapped in one or other form of modern-day slavery, it may never be possible to get an accurate measure of prevalence due to the clandestine nature of the industry. For example, there are no data available on the numbers of migrant children trafficked from countries such as Pakistan, Bangladesh, and some East African Countries to Gulf state, such as the United Arab Emirates and sold to wealthy sheikhs as camel jockeys [9]. In 2005, the United Arab Emirate banned under $18 \mathrm{~s}$ from being used as jockeys in camel racing, a favourite sport in the Gulf region. The ban was as a result of pressure from human rights campaigners and the international community due to the severe injuries, trauma and sometimes death suffered by the young riders, who have either been bought or kidnapped from their country of origin. However, Anti-slavery International released photo evidence that suggests that children as young as 10 years continued to be used to race camels after the ban [10]. Neither is there accurate data on organ trafficking, a form of trafficking found mostly in Northern African, Central and Southern-Eastern Europe, and Eastern Europe despite the estimate of the United Nations Office of Drug and Crime (UNODC) that up to $10 \%$ of all liver and kidney transplants are carried out with unlawfully obtained organs [1].

The report from the UNODC observes that despite the trend analysis suggesting a global increase in trafficking convictions as a result of enhanced anti-trafficking measures, there are still "vast areas of impunity" ([1], p. 23). Conviction rates in Central Asia and some parts of Europe fell by $25 \%$ in comparison to the previous past 5 years despite the increase in the detection of victims. Kevin Bales, a professor of contemporary slavery in Nottingham University asserts that the fall in conviction rates in Europe results either from more stringent border controls across Europe or from an inability to recognise victims of abuse. Individuals who might have been identified as the victim of a crime in the past in most western European countries are now being treated as illegal migrants and not as victims, and are often deported [11]. 
According to the UNODC report, there are difficulties with relying on conviction data to establish prevalence rates. The Caribbean, Central America, North America, Central and South-Eastern Europe did not convict as many as traffickers as countries in Central Asia, East Europe, Western and South Europe, despite an increase in the detection of victims in the former regions. Similarly, in some regions such as Africa and the Middle East, convictions remain very low in spite of the rise in the detection of victims. Thus the trafficking business in Africa and the Middle East remains an almost risk-free enterprise for traffickers [1].

\section{Profile of traffickers}

Human trafficking is, without doubt, a complex and complicated phenomenon. To help understand it better, one needs to examine the perpetrators, those who engage in the trafficking of vulnerable individuals, their motives, their citizenship and the structures of the trafficking business. Information on the gender of suspected, arrested and convicted offenders in human trafficking indicate that the majority were men [12]. A study of 64 countries carried out by the United Nations Global Plan Action to Combat Trafficking in Persons during the years 2010-2012 highlighted the importance of citizenship and gender, particularly in cross-border trafficking, suggesting that there is often a citizenship connection between traffickers and victims [13]. An earlier report from UNODC also stated that most perpetrators (6 in 10 traffickers) were citizens of the countries where they were convicted, suggesting that victims are acquired and sold to criminal networks in destination countries by the local criminals [14]. The TIP study demonstrated that in spite of high international mobility, people still operated mainly from within their own countries. The report further noted how traffickers go to great lengths to gain the trust of their victims, and local contacts are used to threaten retaliation on family members of victims that resist [15]. Unsurprisingly, the report from the European Union for Law Enforcement Agency (EUROPOL) also noted the high level of foreigner involvement. Thus, traffickers are often involved in both domestic and cross border trafficking [3].

The UNODC report suggests that the importance of trust between traffickers and victims may in part be the reason for the high rate of female offenders in human trafficking than in other crimes. For example, analysis for the number of prosecuted traffickers carried out by the European Commission stated that 25\% of prosecuted traffickers were female while $75 \%$ were male [16]. A report from the European Parliament noted that the rate of female traffickers within the EU was as high as $30 \%$ and that this number was higher in specific regions like the Eastern part of Europe where women become traffickers to escape sexual exploitation themselves. The role played by Nigerian women living in Europe in a highly structured and established system of madam criminal networks was also noted by the report [17]. Broad's [18] study of individuals convicted for human trafficking offences in the United Kingdom confirmed these figures. In 71 cases, $68 \%$ of the offenders convicted for various types of human trafficking offences were men while $32 \%$ were women. Interestingly, data from the European Union report revealed that while $74 \%$ of suspected traffickers with EU citizenship were male, $54 \%$ of non-EU nationals were male [2], suggesting that the prevalence of women as traffickers is higher in non-EU citizens.

Furthermore, Broad [18] argued the importance of understanding the pathways through which women become involved as traffickers, stating that sometimes, intimate relationships between a male and female trafficker will ease the woman's path into offending. The previous victimisation is also a critical pathway to trafficking 
for women. To further illustrate the complexities, intricacies and power relations between the male and female traffickers she cites an extract from her interview with a police officer in which he described a case involving a former victim

“....was, they were a couple, she'd used to work for him, but they got together, and she was sort of promoted to look after the place when he wasn't there and didn't have to, have to have sex with clients anymore. She said that he was violent with her and she'd known (name-victim) was there against her will, but she'd been too afraid to do anything about it, afraid of [name-p1]. I don't know whether that was the case or not, but that was her story" (Broad [18], p. 1065)

The most recent research data collected by the European Commission show that between 2015 and 2016, over 7500 individuals were in contact with either the criminal justice system or police in connection with trafficking within the EU and that $78 \%$ of these cases concerned sexual exploitation [2]. Member states with the highest number of reported persons in contact with law enforcement in connection with human trafficking included Romania, Germany, the Czech Republic, Bulgaria and France [2]. The data revealed that the rate of citizenship for both EU and non-EU states varied depending on whether suspected, prosecuted and convicted traffickers are considered. However, over $84 \%$ of traffickers with EU citizenship were from Romania, France, Germany, Bulgaria and Latvia (in that order) while the top five countries of suspected traffickers with non-EU citizenship were China, Nigeria, Turkey, Albania and Morocco.

According to UNODC, more opportunists, such as those in armed conflicts and terrorist groups have become traffickers, taking advantage of this profit-rich and low-risk crime to fund their cause [1]. The United Nations Security Council Counter-Terrorism Committee Executive Director (CTED) asserted that the Islamic State of Iraqi and the Levant (ISIL), a terrorist organisation, is known to openly trade and buy girls and unmarried women in slave markets. They are using encrypted applications to circulate details of their victims, such as age and marital status as well as photos and price of the women and girls before auctioning them off online [19]. ISIL is not alone as other terrorist groups are turning to trafficking in human beings, particularly women and children, to fund their organisations. The Kurdish Worker Party, now known as the Kurdistan People's Congress, is another known terrorist organisation that uses trafficking in humans to financially support its organisation [20]. Al-Qa'ida in the Islamic Maghreb (AQIM) in West and Central Africa, Macina Liberation Front (FLM) in the centre and south of Mali [21], Boko Haram in north-eastern Nigerian, Al-Shabaab in Somali, are also some of the terrorist organisations that use one or another form of human trafficking to fund their organisation [22].

Cooper [23] referred to individuals involved in such terrorist organisations as psychopaths, maintaining that although the term 'terrorist' is not a medical diagnostic label, a medical approach comparable to that used in identifying psychopathy is required to describe the different manifestations and forms of terrorists. Cooper states that while not all psychopaths are terrorists, and not all terrorists have psychopathic personalities, the salient points of coincidence are too striking to be overlooked. Not everyone agrees with this. Rotman [24] has challenged the characterisation of a terrorist as a psychopath, asserting that while it is undeniable that some terrorists show traits of cold-bloodedness and insensitivity akin to specific personality disorder diagnostic criteria, this is insufficient rationale for conclusively diagnosing terrorists as psychopaths. Rotman warned against such labelling, arguing that it can lead to legal defences or act as a mitigating factor that undermines the criminalisation of serious human rights violations. Furthermore, others note that 
what is important is understanding the terrorist's specific motivations, as there is evidence to suggest that terrorists are fundamentally ordinary people motivated by situational factors [25].

In 2017, The United Nations Security Council in resolution 2388 reiterated its deep concern that trafficking in persons in areas affected by armed conflicts continues to occur [26]. An intersection of various elements characterising armed conflicts increases the risk of trafficking in humans. One common consequence of armed conflict is the loss of the rule of law which is meant to protect and defend people in time of peace [27]. Trafficking is part of the strategy employed by armed groups not just to instil fear in the local population by projecting a violent image of themselves, but also to increase their military authority and economic resources [1]. For example, the crime of human trafficking persists in Libya as different armed groups have filled the vacuum created by civil unrest, lawlessness, and lack of government [28]. These groups sometimes clash with each other over the control of the business of human trafficking which is highly profitable, particularly of vulnerable migrants en route to Europe. Migrant women, especially Sub-Saharan women are exposed to forced prostitution and sex trafficking in brothels, particularly in the south of Libya by these armed groups and smugglers [29]. One of such clashes is the violent confrontation that took place in the town of Sabratha in Libya where wealthy smugglers and militias involved in human trafficking teamed up to fight against ISIL, whom they saw as a threat to their profitable business of human trafficking [28].

Traffickers vary in how they are organised but trafficking operations generally fall within three categories. The first category may involve a loose network of organised criminals, soloist or individual traffickers, or a highly structured international trafficking network. Individual traffickers, also known as amateur traffickers or soloists, are at the far end of the continuum and are involved in the recruitment, transportation and exploitation of their victims. In the second category of traffickers, there are no soloist/individual operations, instead, it is a small group of organised criminals who may be part of a small scale international trafficking or involved in local trafficking. This category of the criminal network is highly flexible and often comprised of friends and family members. Another form of this category may consist of the more sophisticated and middle size group, which provides the international sex market with its victims, selling victims to brothel owners in destination countries. These traffickers are sometimes involved in organising the rotation of victims between towns and states. The third category is an extremely structured criminal network that controls the entire trafficking process, from recruitment to the exploitation and disposal of victims. Other services which they may provide include forged documents and ensuring the continuity of relationship with corrupt government officials [30].

\section{The 'rewards' of human trafficking}

An examination of the reward/value/and financial worth of human trafficking enterprise may help our understanding of why more people are entering this illegal business, as data from 2013 to 2014 showed a $7 \%$ increase in the number of traffickers that entered the trafficking industry [3]. The exploitation of human beings is profitable for criminal networks and is second only to the drugs trade as a source of illicit profit. The ILO estimated in 2005 that the total illegal proceeds from the trafficking of people in 2005 were $\$ 32$ billion per year. As of 2012, the profit on forced labour, including sexual exploitation, had risen to $\$ 150.2$ billion per year, with forced sexual exploitation accounting for $\$ 99$ billion and labour 
exploitation 51.2 billion, making it the fastest growing generator of illicit proceeds [8]. The highest total annual profits were in Asia and developed economies, at $\$ 51.8$ billion and $\$ 46.8$ billion respectively, while the regions of Africa, the Middle East, Latin America/Caribbean, and Central/South-eastern Europe accounted \$51.6 billion [22]. The report estimated that the global profit per trafficked victim varied significantly based on the nature of the exploitation, which ranged from $\$ 21,800$ yearly for sexual exploitation to $\$ 2300$ for domestic labour.

Despite the lack of consensus on the estimate of persons whose organs have been trafficked illegally, a report from the Global Financial Integrity estimated that $10 \%$ of all transplants are carried out with organs that have been acquired unlawfully. According to the report, 120,000 organ transplants were performed worldwide in 2014. Thus, 12,000 operations performed that year were illegal, and this estimate comprises of only the sales of the five organs most sought after i.e., kidneys, livers, hearts, lungs, and pancreas. The report estimates that the illegal trade conservatively generates between $\$ 840$ million and $\$ 1.7$ billion, with the kidney as the most frequently transplanted organ, both illegally and legally [31].

In the context of terrorism and armed conflict, both the Office of the High Commissioner for Human Rights (OHCHR) and the Financial Task Force (FATF) have described in detail how the Islamic State of Iraq and the Levant (ISIL) fighters buy and sell Yazidi women, in slave auctions and online, for amounts ranging from $\$ 200$ to $\$ 1500$ [32]. An earlier report from FATF had reported on how internal guidance was provided to ISIL fighters on the number of slaves they were allowed to keep and maintain, and that the soldiers were allowed to pay as low as approximately $\$ 13$ for a slave [33]. In 2016, ISIL gave the Yazidi families the choice of paying $\$ 850,000$ for the return of 200 victims kidnapped from the Yazidi community in the town of Sinjar or for the victims to be sold in the slave auction. Evidence suggests that in 2014 alone, ISIL earned between $\$ 35$ million and $\$ 45 \mathrm{mil}$ lion in payment from the Yazidi community alone [22]. The United Nations Security Council's report states that Mahamadou Ag Rhissa, a businessman alleged to be involved in terrorism and human smuggling, holds women captive and allows them to be sexually exploited until payment of between 150,000-175,000CFA Franc, approximately $\$ 300-\$ 350$ is paid to him United Nations Security Council [34].

\section{Trafficking as part of the demand and supply chain}

Human Trafficking is a market that treats people like commodities through buying and selling. Demand for cheap labour and prostitution has always existed, and while the intricate and complex link between demand and supply is undeniable, increased wages in highly industrialised nations, specifically in the unskilled labour market, has contributed to this growth in demand [30]. According to Taylor and Jamieson [35], the supply of trafficked persons from specific developing countries is a function of specific economic conditions in these countries, while the demand for the services they are expected to give is also a function of specific social and economic processes in the industrialised nations. This aligns with Siddharth Kara's analysis of sex trafficking, who explains that for market forces to create a supply that meets a specific demand, other market forces must have generated the demand for that particular product in the first place since an industry needs both forces to exist [36]. Collins dictionary defines demand as to claim as a right (www.collinsdictionary). Referencing the Nordic model on prostitution, Raymond asserts that without male demand, the supply of women for commercial sex will decrease, as the market cannot survive without its consumers [37]. The implication is that traffickers must be sure of the profitability of the business to continue in the industry. 
Thus, the profit traffickers make from trafficking their victims must exceed the cost of bringing these victims from the source countries [38].

Using the analogy of sex trafficking as a disease infecting humanity to illustrate his point, Kara notes that trafficking has two components, slave trade (supply) and slavery (demand). He asserted that an understanding of sex trafficking's molecular anatomy acquisition, movement and exploitation, means understanding the modus operandi of the industry, which in turn will expose the business's vulnerable points, the forces of demand and the drivers of profit. He claimed that not only will the best strategies for treating the infection (sex trafficking) be found but it will also ensure that the long-term eradication of the condition in the "host organism", namely economic globalisation and poverty that gave rise to the infection in the first place, is addressed [36]. While traditional market theories operate on the presumption that it is a demand that creates supply, other scholars have challenged this theory, arguing that constant supply of unskilled migrant workers forced or willing to provide specific services or accept jobs can generate the demand for such services/labour rather than vice versa [39]. To support their argument, these scholars provide the following as an example:

\begin{abstract}
"For example, in the poor and developing world, many children work as "shoeshine boys", whereas few do so in the affluent world. The absence of this form of child labour in affluent countries and its presence in the poorer nations cannot be explained through reference to different levels of absolute demand for shoe shiners' labour. Here, as elsewhere, the relationship between supply and demand is mediated by a range of economic and social factors, as well as by government policies on employment (including child labour), immigration, education, and welfare" ([39], p. 26).
\end{abstract}

Agreeing with this argument, Aronowitz [40], posits that the availability of certain services creates the demand for them. He argues that the market supply of trafficked women as a result of various socioeconomic factors has generated the demand for them and that the exploitation of these women in the destination country should be blamed on the uneven power relations that occur in patriarchal communities, that objectifies woman for consumption, and other factors that disempower and marginalise. These authors concluded that demand does not just happen, waiting to be answered and that individuals are not born needing or wanting particular products and services. Instead, they learn to want what is available and seen as normal by society.

While their argument has merit and cannot be overlooked, how then can the supply of certain services, particularly in post-conflict areas where large military and predominantly male peacekeeping forces are sent, be explained if not that there was a demand for that specific services? [1] Perhaps one could agree that increased supply can lead to increased demand, but it is quite a different thing and possible going too far to suggest that supply can create demand where no demand previously existed.

\title{
6. Links between psychopaths and traffickers
}

Robert Hare has expanded the construct of psychopathy as a personality disorder, first developed by Hervey Cleckley, exemplified in what is now known as the Hare's Psychopath Checklist-Revised (PCL-R), a 20-item clinical rating scale used in the diagnosis of psychopathy [41]. Cleckley described a small group of patients who appeared sane yet lacked empathy and remorse, were deceptive, impulsive 
and manipulative, and suffered from "emotional poverty" ([42], p. 230), detailing symptoms that Hare has subsequently developed upon [41]. Hare and colleagues, building on Cleckley's work, developed the PCL-R, which describes psychopathy as a pattern of interpersonal, affective, lifestyle and antisocial traits and behaviours. High scores in this area are associated with outcomes such as greater criminality [43].

The PCL-R 20 items include glibness and superficial charm, grandiose sense of self-worth, need for stimulation and/or proneness to boredom, pathological lying, cunning and manipulation, lack of remorse or guilt, shallow affection, callousness and/or lack of empathy, parasitic orientation, poor behavioural controls, promiscuous sexual behaviour, early behavioural problem, lack of realistic, long term goals, impulsivity, irresponsible, failure to accept responsibility for own actions, having had many short term marital relationships, juvenile delinquency, revocation of conditional release [41]. The PCL-R has evolved from a two factor model of (1) interpersonal and affective factor, reflecting unemotional and callous traits and (2) lifestyle and anti-social factors reflecting reckless, impulsive and criminal behaviour to a four-factor model that identifies features in four domains: (1) interpersonal, (2) affective, (3) lifestyle, and (4) antisocial [44].

Malatesti and McMillian [45] have defended philosophically the use of Hare's concept of psychopathy against criticism from some quarters questioning the validity of the scale as a diagnostic tool for identifying psychopathy. They asserted that in a practical sense the PCL-R is a robust scientific (p. 12) concept because it allows empirical research to be conducted upon the neural bases of individual functional impairment. The view of psychopathy as a personality disorder has also been criticised. Cowan [46] argues that the diagnosis of psychopathy as an antisocial personality disorder reduces the appalling moral insanity of the psychopath. According to Cowan, psychopaths, are capable of learning the rules of public interaction and social conducts, not because they care about these things but because it serves their purpose. The problem is not necessarily what the psychopath does, but his relationship to what he does; the psychopath understands right from wrong but does not understand why [47].

Cowan ([46], p. 296) describes psychopathy as an 'absence and deficit' of relatedness the absence of Aidos (the winged goddess of ancient Greece, also known as "shame", that exposes us to condemning eyes for what we have said or done that we should not have), and Eros (the ancient Greek god that brings things out of chaos, infusing a conscience in us that allows desires to be fulfilled in such a way that our loving is rewarding to ourselves and our beloved). She therefore focuses on the principle of relatedness and those capacities that allow us to be able to relate to each other ethically. She maintained that being a psychopath means that the character structures lack something important at the core that enables individuals to relate to each other empathically. This deficit is understood to explain the apparent absence of morality, ethics, shame or guilt.

In analysing the link between psychopathy and crime, Hare and colleagues [41] highlight disproportionate representation of those diagnosed as psychopaths, using the PCL-R, in the criminal justice system. Hare and his colleagues particularly noted that psychopaths have high crime rates, arguing that their poor behavioural control and impulsivity might lead to reactive forms of violence and aggression, which is perhaps why they can easily intimidate and victimise the vulnerable with force as a tool to achieve control and power over others. It has been argued that these traits of violence, aggression, control and power are not unlike those associated with human traffickers. Spidel et al. [48] comment on the prevalence of psychopathic offenders with regard to sex trafficking, expressing their discontent at the fact that little attention has been paid to examining the role of psychopathy in traffickers who 
pimp women in prostitution for profit. In their analysis of 22 perpetrators using the PCL-R, they found that one-third of the pimps examined met the diagnostic cut-off point in the PCL-R for a diagnosis of psychopathy. The characteristics of the pimps were consistent with those of a psychopath. Spidel and colleagues described how at the recruitment stage, these pimps employed charm by professions of love/friendship for his victim, and the promise of material and financial gains to lure his victim into the sex trade. As he becomes more controlling and domineering, he eventually resorts to violence, or the threat of violence to control the victims that resist. Reid [49] made a similar observation in her analysis of the parallels between the characteristics and strategies employed by traffickers to entrap and keep their victims and those associated with psychopaths. Some of the characteristics and tactics used by the traffickers that Reid identified include romancing or flattering the victim, building trust or becoming an ally with her, drugging or isolating her, lies and false promises, and the use of coercion through intimidation or the threat of violence.

A review of the literature on the methods used by traffickers on their victims also demonstrates this similarity, as traffickers use manipulations to charm and lure victims into the sex industry, seize their earning and use psychological coercion, violence and intimidation to extract complete obedience and authority [50]. Greer and colleagues compared the characteristics of traffickers to those of psychopaths that include acts of brutality and violence, lack of guilt, empathy or remorse for their victims. Referencing several court cases where traffickers have used the most extreme kind of violence and threat to control and manipulate the victims, they stated that when a comparison is made on the most extreme sexual offenders, it is essential to remember that traffickers have similar character and behaviour profiles to psychopaths.

\section{Conclusion}

The above discussion has highlighted trafficking as a profitable industry and raised the question as to whether the business rewards of trafficking act as a primary motivator for trafficking or whether motivation for trafficking might be better or alternatively explained by the presence of psychopathic features in traffickers. Research is limited on this question preventing us making definitive conclusions. It must also be acknowledged that there is considerable diversity inherent in the phenomenon of trafficking and it may be too simplistic to consider all traffickers within the same lens. However, given the cost to society of trafficking, the physical and mental health consequences of trafficking for victims that places a considerable burden not only on those individuals trafficked but also on health systems, it is important to examine the motivations and characteristics of those who traffic if attempts to intervene in trafficking are to be successful. While mental health-related issues are the most dominant in trafficking cases due to psychologically traumatic events, other experiences associated with trafficking includes chronic physical pain, sexually transmitted disease such as HIV/AIDS, reproductive and sexual health complications, unwanted pregnancies, complications from unsafe termination, physical disability, acute injuries, sleep problem, torture and even death [51]. The financial gain to traffickers is undisputed. However, the authors suggest that in order to understand the motivation for trafficking better, it is necessary to examine the characteristics of the trafficker. It is evident from the research conducted in this field that traffickers are often charming and display a grandiose sense of self-worth to convince their victims of their importance. There is also evidence to suggest that they are pathological liars, cunning and manipulative as they knowingly make false promises of jobs and a better life to vulnerable victims, 
but more importantly, they have no remorse for their action, as the victim is seen merely as a commodity to use and re-use for profit. In the global efforts to prevent human trafficking, a better understanding of the motivation for trafficking is essential. This understanding will shape interventions for prevention. The question of whether human traffickers are in it for the profits or are motivated by psychopathic tendencies, or both, is one worthy of further investigation.

\section{Acknowledgements}

The authors wish to acknowledge Dublin City University for providing funding towards the first author's dissertation work.

\section{Author details}

Jennifer Okeke, Mel Duffy and Rosaleen McElvaney*

Dublin City University, Dublin, Ireland

*Address all correspondence to: rosaleen.mcelvaney@dcu.ie

\section{IntechOpen}

(C) 2020 The Author(s). Licensee IntechOpen. This chapter is distributed under the terms of the Creative Commons Attribution License (http://creativecommons.org/licenses/ by/3.0), which permits unrestricted use, distribution, and reproduction in any medium, provided the original work is properly cited. (cc) BY 


\section{References}

[1] United Nations Office on Drugs and Crime. Global Report on Trafficking in Person Booklet 1. Vienna, Austria: United Nations; 2018

[2] European Commission. Data Collection on Trafficking in Human Beings in the EU. Belgium: European Union; 2018

[3] The European Union Agency for Law Enforcement Cooperation. Situation Report: Trafficking in Human Beings in the EU. The Hague: EUROPOL; 2016

[4] Hargreaves-Cormany HA, Patterson TD, Muirhead YE. A typology of offenders engaging in the Sex Trafficking of Juveniles (STJ): Implications for risk assessment. Aggression and Violent Behavior. 2016;30:40-47. DOI: 10.1016/j. avb.2016.06.011

[5] Aronowitz AA, Koning A. Understand human trafficking as a market system: Addressing the demand side of trafficking for sexual exploitation. Journal Revue Internationale de Droit Pénal. 2014;85: 669-696

[6] International Labour Organisation (2005) Forced Labour and Human Trafficking: Estimating the Profits. Geneva: International Labour Organisation

[7] International Labour Organisation. Profits and Poverty: The Economic of Forced Labour. Geneva, Switzerland: International Labour Organisation; 2014

[8] International Labour Organisation. Global Estimates of Modern Slavery: Forced Labour and Forced Marriage. Geneva: International Labour Organisation; 2017

[9] Popkin J. NBC: Boys Forced to be Camel Jockeys in UAE. New York: National Broadcasting Company; 2006
[10] Anti-Slavery International. Ten Year Olds Forced to Risk Lives Racing Camels in UAE. London, UK: Anti-Slavery International; 2010. Available from: https://www.antislavery.org/ten-yearolds-forced-risk-lives-racing-camelsuae/ [Accessed: 28 March 2019]

[11] The Guardian. Trafficking Conviction Fell 25\% Despite Rising Number of Victims in Europe. London, UK: The Guardian; 2019

[12] United Nations Office on Drugs and Crime. The Globalization of Crime. A Transnational Organised Crime Assessment. "A Ground-Breaking Assessment of Transnational Organized Crime Activities that INTERPOL will Use in Its Work." Vienna, Austria: United Nations Office on Drugs and Crime; 2010

[13] United Nations Office on Drugs and Crime. Global Report on Trafficking in Person. Vienna/Geneva: United Nations Office on Drugs and Crime; 2014

[14] United Nations Global Initiative to Fight Human Trafficking. Global Report on Trafficking in Persons. Vienna, Austria: United Nations Office on Drugs and Crime; 2009

[15] United Nations Office on Drugs and Crime. Global Report on Trafficking in Persons. Vienna, Austria: United Nations Office on Drugs and Crime; 2016

[16] European Commission. Eurostat Methodologies and Working paper. Trafficking in Human Beings. Luxembourg: European Union; 2013

[17] European Parliament. The Gender Dimension of Human Trafficking. Strasbourg, France: European Parliament Research Service; 2016. Available from: https://epthinktank.eu/2016/02/10/ 
the-gender-dimension-of-humantrafficking/ [Accessed: 28 March 2019]

[18] Broad R. 'A vile and violent thing': Female traffickers and the criminal justice response. British Journal of Criminology. 2015;55(6):1058-1075. DOI: $10.1093 /$ bjc/azv072

[19] United Nations Security Council, Counter-Terrorism Committee Executive Directorate. Identifying and Exploring the Nexus between Human Trafficking, Terrorism, and Terrorism Financing. New York: United Nations Security Council, Counter-Terrorism Committee Executive Directorate; 2017

[20] Cinar B. Human trafficking is used for recruiting terrorists. In: Second Annual Interdisciplinary Conference on Human Trafficking. University of Nebraska; 2010

[21] The Financial Action Task Force. Anti-Money Laundering and CounterTerrorism Financial Measures. Paris, France: The Financial Action Task Force; 2016

[22] The Financial Action Task Force. Financial Flows from Human Trafficking. Paris, France: The Financial Action Task Force; 2018

[23] Cooper HHA. Psychopath as terrorist. Legal Medical Quarterly. 1978;2(4):253-262

[24] Rotman E. Therapeutic jurisprudence and terrorism. Thomas Jefferson Law Review. 2008;30(2):525

[25] Sageman M. Understanding Terror Networks. United States of America: University of Pennsylvania Press; 2004

[26] United Nations Security Council. Report of the Secretary General on Trafficking in Person in Armed Conflict Pursuant to Security Council, Resolution 2388 (2017). New York: United Nations; 2018.
Available from: www.un.org/sc/ ctc/news/document/s-2018-1042report-secretary-general-traffickingpersons-armed-conflict-pursuantsecurity-council-resolution-2388-2017/ [Accessed: 22 March 2019]

[27] United Nations High Commissioner for Refugees. Global Trends. Forced Displacement in 2017. Vienna, Austria: United Nations High Commissioner for Refugees; 2017

[28] Global Initiative Against Transnational Organised Crime. Responding to the Human TraffickingMigrant Smuggling Nexus. With a Focus on the Situation in Libya. Geneva, Switzerland: Global Initiative Against Transnational Organised Crime; 2018

[29] Refworld. 2018 Trafficking in Persons-Libya. United States of America: United States Department of States; 2018. Available from: https:// www.refworld.org/docid/5b3e0af04. html [Accessed: 28 March 2019]

[30] United Nations Global Initiative to Fight Human Trafficking. Analysing the Business Model of Trafficking in Human Beings to Better Prevent the Crime. Austria: Organization for Security and Co-operation in Europe; 2010

[31] Global Financial Integrity. Transnational Crime and the Developing World. Washington, DC: Global Financial Integrity; 2017. Available from: https://www.gfintegrity. org/wp-content/uploads/2017/03/

Transnational_Crime-final.pdf [Accessed: 28 March 2019]

[32] Office of High Commissioner for Human Rights. "They came to destroy" ISIL Crimes Against the Yazidis.

Geneva, Switzerland: Office of High Commissioner for Human Rights; 2016. Available from: https://www.ohchr.org/ Documents/HRBodies/HRCouncil/ CoISyria/A_HRC_32_CRP.2_en.pdf [Accessed: 28 March 2019] 
[33] The Financial Action Task Force. Financing the Terrorists Organisation Islamis States in Iraqi and the Levant (ISIL). Paris, France: The Financial Action Task Force; 2015

[34] United Nations Security Council. Mahamadou Ag Rhissa. 2018.

Available from: https://www.un.org/ securitycouncil/content/mahamadouag-rhissa [Accessed: 04 April 2019]

[35] Taylor I, Jamieson R. Sex trafficking and the mainstream of market culture. Crime, Law and Social Change. 1999;32(3):257-278. DOI: 10.1023/A:1008302724190

[36] Kara S. Sex Trafficking. Inside the Business of Modern Day Slavery. United States: Columbia University Press; 2009

[37] Raymond JG. Prostitution on demand: Legalizing the buyers as sexual consumers. Violence Against Women. 2004;10(10):1156-1186. DOI: $10.1177 / 1077801204268609$

[38] Wheaton EM, Schauer EJ, Thomas V. Economics of human trafficking. International Migration. 2010;48(4)

[39] Anderson B, O’Connell Davidson J. Trafficking-A demand led problem? A multi-country pilot study. Save the Children. Stockholm, Sweden; 2002

[40] Aronowitz AA. Human Trafficking, Human Misery: The Global Trade in Human Beings. London: British Library Cataloguing; 2009. Available from: https://is.cuni.cz/studium/predmety/ index.php?do $=$ download $\&$ did $=33454 \&$ kod=JPM346 [Accessed: 28 March 2019]

[41] Hare RD, Neumann CS.

Psychopathy: Assessment and forensic implication. The Canadian Journal of Psychiatry. 2009;54(12):791-802

[42] Hare RD, Black PJ, Walsh Z. In: Archer RP, Wheeler EMA, editors.
Forensic Uses of Clinical Assessment Instrument. 2nd ed. London, UK: Routledge; 2013. pp. 230-254

[43] Gray NS, Hill C, McGleish A, Timmons D, MacCulloch MJ, Snowden RJ. Prediction of violence and self-harm in mentally disordered offenders: A prospective study of the efficacy of HCR-20, PCL-R, and psychiatric symptomatology. Journal of Consulting and Clinical Psychology. 2003;71(3):443-451. DOI: 10.1037/0022-006X.71.3.443

[44] Neumann CS, Hare RD, Newman JP. The super-ordinate nature of the psychopathy checklist-revised. Journal of Personality Disorders. 2007;21(2):102-117. DOI: 10.1521/ pedi.2007.21.2.102

[45] Malatesti L, McMillan J. Defending psychopathy: An argument from values and moral responsibility. Theoretical Medicine and Bioethics. 2014;35(1):7-16. DOI: $10.1007 /$ s11017-014-9277-5

[46] Cowan L. The psychopath: What's love got to do with it? Psychological Perspectives. 2014;57(3):291-311. DOI: 10.1080/00332925.2014.936241

[47] Hoppenbrouwers SS, Nazeri A, Jesus DRD, Stirpe T, Felsky D, Schutter DJLG, et al. White matter deficits in psychopathic offenders and correlation with factor structure. PLoS One. 2013;8(8):e72375. DOI: 10.1371/ journal.pone.0072375

[48] Spidel A, Greaves C, Cooper BS, Herve H, Hare RD, Yuille JC. The psychopath as pimp. The Canadian Journal of Police \& Security Services. 2006;4(4):205-211

[49] Reid JA. Entrapment and enmeshment schemes used by sex traffickers. Sexual Abuse: A Journal of Research and Treatment. 2016;28(6):491-511. DOI: $10.1177 / 1079063214544334$ 
[50] Greer BT, Cotulla G,

Seddighzadeh H. Should sex traffickers

be subject to sexually violent predator

laws? Journal of Criminal Psychology.

2016;6(3):121-133. DOI: 10.1108/

JCP-03-2016-0008

[51] Zimmerman C, Hossain M, Watts C.

Human trafficking and health: A

conceptual model to inform policy,

intervention and research. Social

Science \& Medicine. 2011;73(2):327-335.

DOI: $10.1016 /$ j.socscimed.2011.05.028 


\title{
Chapter 6
}

\section{Child Trafficking: The Construction of a Social Problem}

\author{
Paula Cristina Martins
}

\begin{abstract}
Child trafficking is a public health problem and a serious violation of human rights. However, it is not a product of modern times; rather, it is a phenomenon observed across history. Nevertheless, it is not viewed as a social problem because it only affects a limited number of individuals, and these individuals are children. In fact, the social status of children and the importance attached to their difficulties, the social exclusion of problem children (the children of others), and the double negativity attributed to child victims might explain why this crime is not generally recognized as a problem that must be addressed. As a topic of high consensus and low intensity, its increasing presence in the political discourse and in child protection practices is not accompanied by the active involvement of the general population in its prevention or combat. In this chapter, we discuss the ambivalent presence of child trafficking in Portugal and within Europe, considering the official data on the phenomenon with regard to the aspects of crime and victimization.
\end{abstract}

Keywords: child trafficking, social problem, victims, child protection, trafficking in human beings

\section{Is child trafficking perceived as a social problem in Portugal?}

We live in a time in which claims proliferate about a multitude of issues regarding social reality and people's lives. Because some of these issues are understood as adversely affecting a significant part of the population, they create a collective discourse and demands for action. When important societal groups (e.g. politicians, social change groups, the news media and numerous citizens) recognize these claims as legitimate and valid, they become social problems. As such, from a social constructionist perspective, the emergence and recognition of social problems are based on both the empirical evidence of their existence and impact as well as on the perceptions of their implications and need to be solved [1].

As Best [2] mentioned, social progress paradoxically creates social problems for different reasons. On the one hand, it generates a general expectation of perfectibility, which fosters a growing intolerance towards social difficulties and shortcomings. On the other hand, as the biggest challenges of humanity are within our reach (e.g. increased life expectancy, control of diseases), those that once were considered small now seem bigger and more serious (e.g. quality of life, lifelong learning). Moreover, the growing exigence of societies, together with the multiplication of relationships and communication networks, lowers the tolerance threshold of the population. Finally, because social progress improves life expectancy and standards of living, it fosters fears of loss as well as inflates perceived risks and defensive postures [2]. 
At given times and in relation to certain phenomena, a discrepancy exists not only between social perceptions and the available data on the issues but also among the perceptions of different social groups. For instance, policymakers might be attentive to a certain subject based on their knowledge, and this view might not be shared or valued in the same way by society as a whole. We believe that child trafficking meets this standard worldwide and, specifically, in Portugal.

Regarding Portugal, the following reasons (some general, others countryspecific) are put forward to contend that child trafficking is not perceived as a social problem as previously defined: (i) it is relatively unknown among most of the population, (ii) it involves children as victims, (iii) it involves children who are often from disadvantaged backgrounds and/or foreign origins, (iv) it is a police matter and (v) it involves a small group of the population.

Let us discuss each aspect briefly.

\section{A strange social phenomenon: the role of media and research}

Research on the public awareness of trafficking in human beings (THB) is scarce. However, as Sharapov [3] asserts, it is a distant subject for most of the population. Various European countries (e.g. Scotland, Belgium, Czech Republic, Finland and Romania) generally view it as having little relevance to their daily lives. This sense of detachment is not so much due to the lack of information on the subject, as to how this information is framed (i.e. primarily as a legal and criminal issue on the margins of normal everyday life) [4]. Portuguese reports on people's awareness of human trafficking are in line with this general tendency. In a study conducted by Sani, Nunes and Caridade [5], the authors used a convenience sample to find that most respondents showed a poor understanding of THB and recognized the lack of information concerning this phenomenon in Portugal. Most participants viewed THB as the exploitation of immigrants and socially disadvantaged people in search of work. More than half (58.5\%) had not heard any information about it over the last 2 years. Among those who had heard information, social media stood out as the privileged method of communication regarding this phenomenon.

Although the relationships among public opinion, the media and public policies are complex and controversial, the available evidence shows that political and media discourses on human trafficking significantly influence public opinion, and (conversely) public opinion affects media and policymaking [3, 4].

With regard to Portugal, the role the media plays in framing the public discourse on human trafficking has received specific attention. Research examining the written press between 2001 and 2004 [6] substantiated the media representation of human trafficking as infrequent, superficial and stereotyped. News on this topic was poor, barely visible and associated with criminal activity and deviant people from other countries and minorities. In a second study focusing on the news published in a tabloid newspaper in 2008, despite the increased visibility of the phenomenon, Couto, Machado, Martins, and Gonçalves [7] identified similar trends in the coverage: it was framed as a criminal problem, essentially involving deviant groups, and is generally related to illegal immigration. This representation facilitates the adoption of a passive and moralizing attitude of devaluation regarding the phenomena and depreciates the people involved. As has been indicated with regard to child trafficking in other European countries [8], a cross-border problem that affects almost only asylum seekers and immigrants or particular cases is unlikely to affect the general community. This assumption leads to the underestimation of the risks of child trafficking and to the weakening of the social relevance of prevention and protection strategies. 
Research on human trafficking and, in particular, child trafficking, is critical. Producing and disseminating knowledge helps sensitize people in general. Moreover, it substantiates more effective processes of identification, prevention, and protection, as well as helps support victims and prosecute criminals [9].

As Clemente [10] stated, the Portuguese investigation concerning human trafficking has developed more slowly and inconsistently than that in other countries (the first publications date back to 2000) [11]. Driven by the increasing attention of the national authorities to the phenomenon, within the framework of international agreements, the academic research made its greatest development beginning in 2007 onwards. As in other European countries, where the empirical literature on child trafficking is scarce [12], the scientific approach to this problem in Portugal since the beginning consisted primarily of secondary research articles on the sexual exploitation of women based on official statistics. For various reasons, this research appears to report only one-third of the referrals per year [11]. Reports on the prevalence of the phenomenon to monitor and evaluate prevention, protection and rehabilitation programmes have been more systematic and frequent than that regarding trafficked victims, the circumstances of their victimization or the trafficking process, its rationale, dynamics and other people involved. Nevertheless, the study of the social representations of human trafficking, in particular those of specific groups including practitioners, has been a significant part of the investigation undertaken in Portugal in this field, yet with sampling limitations. In these types of scholarly papers, child trafficking is often referred to in connection with the characterization of the age of the victims. However, research specifically focusing on child trafficking is scarcer. In this regard, the RCAAP ${ }^{1}$ portal is a privileged source of access to Portuguese academic production. From 2006 to 2016, 12 papers on human trafficking were registered from Portuguese repositories [13]. However, only eight titles include the keywords "child trafficking" as of 2019: a working paper and seven master's theses.

In short, the still incipient scientific production and media coverage focusing on criminal cases reinforce the lack of information associated with public opinion and, to that extent, create a distance with regard to this phenomenon.

\section{The status of victims: children}

As has been elaborated elsewhere [14], a widespread social consensus exists regarding child welfare matters. Although these matters are frequently used by politicians and the media as rhetorical devices and emotional assets [15], this discursive intensity is not always consistently translated into policies or practices. On the other hand, this unanimity, even if it arouses ethical shock and emotional indignation, does not induce social pressure or collectively persistent action in relation to children's issues.

If children whose parents fail to protect their best interest are socially vulnerable, relatively invisible and voiceless, child victims are viewed even as more helpless. This issue is especially relevant because, as Gearon [16] argued, child trafficking narratives are pervaded by the notion of victimhood, conveying representations of helplessness, vulnerability and lack of agency. This convergent negativity (those of children and victims) [14] easily evokes empathic social responses but does not necessarily make the victim a priority.

\footnotetext{
${ }^{1}$ RCAAP is a Portuguese digital platform that aggregates the open access scientific production registered in the national institutional repositories and, since 2010, also the scientific production of Brazil available from the Brazilian Institute of Information Science and Technology (IBICT).
} 
Furthermore, the formal requirements for eligibility to the protection system, which are understood in light of the social representations of victimhood, create a paradox. On the one hand, the confirmation of the status of a victim is a mandatory requirement for accessing assistance. On the other hand, when victims do not comply with the social expectations of powerlessness and passivity, the question of their responsibility often arises regarding the situation in which they find themselves. Although they are children, if their participation in trafficking is understood as active and voluntary, then their status as child victims gives way to that of the criminal children: those who should be blamed, convicted and punished, rather than protected [16]. Although the victim is viewed as an object of behaviors and situations beyond their control or ability to self-determine, the circumstances of children allegedly involved in criminal activities are dimmed, and their behaviors and condition tend to be abstracted and decontextualized [14]. In short, whether they match the stereotype of a victim or not, children who are victims of trafficking have no voice or do not deserve to be heard. Either case applies to what Clemente [10] called "the deafening silence of trafficked people" (p. 663).

\section{The status of victims: poor, deviant and from abroad}

Public opinion is an indication of societal attitudes towards certain phenomena. With regard to human trafficking, if public opinion expresses the culture of society, then it might reflect the social discrimination of women and children as well as a social tolerance towards violence and exploitation [8], which would enable an understanding of the symbolic construction of this phenomenon. On the other hand, because public opinion influences policymaking, if well-formed and informed, it can also help reduce the structural factors that underlie trafficking [3].

Victims of child trafficking and exploitation often come from abroad and the margins of society. According to the final report of the study of groups at high risk for human trafficking in the European Union [8], the risk of child trafficking is significantly higher for children with disabilities or who engage in risky behaviors, from dysfunctional, disadvantaged and/or social excluded families, communities or neighborhoods in areas of conflict or crisis. Generally, they might be viewed as problem children. This label reinforces their inherent negativity [14], social invisibility and exclusion [17]; they are the children of others. As such, instead of a positive approach to the phenomenon based on a human rights perspective, they might evoke attitudes of socially organized denial [18], rejection, disinterest or criticism.

\section{Framing the phenomenon: a justice system problem}

Thus, the genesis of trafficking is essentially sociopolitical, culminating in a legal phenomenon. Experts [16] have criticized the criminal perspective that has dominated child trafficking "as immigration-led and prosecution-focused" (p. 497) and as a threat to human and state security [19]. This simplistic view overshadows the broader dimension of the phenomenon, which as Gearon [16] asserted is not limited to international movements (legal or illegal) or migrant children. In fact, as Palmer [20] claimed, child trafficking is a complex, multidimensional and dynamic process; it is a shape-shifting phenomenon characterized by different patterns across countries. It involves national citizens, migrants (i.e. other EU citizens), immigrants from third world countries, children with their families and unaccompanied asylum-seeking children. It might begin long before it is detected, with or without family involvement, for a variety of purposes, and as part of more or less 
sophisticated networks. However, according to Crawley's research in the UK [21], even the intervention of health and welfare professionals is permeated by the logic of immigration control [22], where the concern with the protection of the territory overrides that of children. In the same vein, Clemente [10] characterized the Portuguese support system for victims of trafficking as victim-oriented in theory but as focused on internal security objectives in practice. This feature corresponds to the current trend of protection systems, which are increasingly focused on control rather than care [23].

This partial viewpoint hinders interventions focused on the rights and needs of children and their protection [16]. As experts have argued, the majority of children who eventually become victims of exploitation and/or trafficking have previously been deprived of their rights [24]. In this sense, they contend that the criminal matrix of the definition of child trafficking frequently overshadows its true nature and origin: child trafficking is primarily a matter of rights and protection, and, as such, it reveals the shortcomings of protection and welfare systems [24, 25]. Therefore, the priority or almost exclusive emphasis on legal and procedural aspects and the subsequent production of penal legislation, national action plans and support measures for victims at the expense of action towards the structural conditions that underlie trafficking are criticized. Enforcing the United Nations Convention on the Rights of the Child is the most effective way to prevent the exploitation and trafficking of children and youth as well as safeguard their rights and respond to their needs.

\section{The extent of the problem: statistics and relevance}

Data available on human trafficking and, specifically, child trafficking provide only an approximation of the reality. In addition to being a hidden phenomenon [19], illegal and clandestine [26], concepts of trafficking differ across countries as various reports have highlighted. Because trafficking is usually closely connected to crimes such as illegal immigration, aid to illegal immigration, forgery and criminal association, the distinction among these phenomena is not clear [24]. Consequently, defining these terms involves a wide range of legislation [27] and a variety of mechanisms to identify phenomena. Furthermore, even at the national level, experts have identified many discrepancies in the data reported across different sources, as in the case of Portugal [11]. These findings support the idea of numerous unreported cases (the dark figures of trafficking). Therefore the low numbers of child trafficking represent the tip of the iceberg $[19,28]$.

Additionally, the eligibility criteria for acquiring the status of trafficking victim and receiving assistance significantly modify the available data on this phenomenon.

Especially with regard to child trafficking, the criterion used to set the age of the victim, whether at the time of referral or at the beginning of trafficking, remains a sensitive issue. Neves and Pedra [11] drew attention to the fact that many victims have been subjected to exploitation for several years, even though their identification in the system occurred during adulthood. This consideration provides a different basis for calculating the number of child trafficking victims as well as targets and adjusts the interventions made available to people in these conditions within the legal and protection systems. In fact, according to Catch and Sustain [29], trafficked children (especially those with a long history of being exploited) tend to be treated by the legal and the protection systems according to their immigration status or the crimes in which they might have been involved, rather than the crimes that they have suffered along the way. This procedure is contrary to Directive 
2011/36/EU, which recommends the development of comprehensive child-sensitive protection systems and the mobilization of recovery processes as soon as children are identified as victims of trafficking.

Another eligibility criterion concerns the distinction between the child trafficking statistics and the risk of child trafficking (i.e. trafficked children and those vulnerable to exploitation and trafficking). In line with this view, researchers have claimed that the groups of children targeted to prevent and combat trafficking (currently unaccompanied asylum-seeking children, child victims of trafficking and child victims of sexual exploitation) should be revised to include accompanied child migrants, undocumented children and homeless children [24]. According to scholars and practitioners, within the logic of prevention and effective interventions, authorities should expand their focus to include children at risk of being trafficked, favoring more comprehensive interventions in addition to focused responses. This option would imply overcoming a segmented view of the intervention, based on children's status, to adopt an ecological, systemic, multidimensional and dynamic perspective of children's vulnerability [24].

For the reasons outlined above and given the absence of reliable and disaggregated data [29], comparisons of national data are far from linear [24].

Nevertheless, despite the scarcity of consistent data, according to the United Nations Office on Drugs and Crime [30], human trafficking could likely reach up to 4 million victims. Most are female (72\%) and trafficked for sexual exploitation, although significant regional variations are observed [30]. The Organization for Security and Cooperation in Europe (OSCE) estimates that children account for over $30 \%$ of the world's human trafficking [31]. According to the $2018 \mathrm{Global}$ Report on Trafficking in Persons, in 2016, 23\% of these children were girls, which is more than double than that identified in 2004 [32]. As the International Labour Organization (ILO) specified, $26 \%$ of the 20.9 million people who were victims of forced labour between 2002 and 2011 were children [33].

As noted in the report of Catch and Sustain [29], child trafficking occurs in all European countries, without a clear division among countries of origin, destination or transit. In the European Union (EU) in 2015-2016, approximately 56\% of the victims identified were from non-EU countries. The majority were female (68\%), and the dominant forms of exploitation were for sexual and labour purposes (56 and $26 \%$, respectively); relevant geographical variations were also observed. Children accounted for $23 \%$ of the victims detected and for $23 \%$ of all victims of trafficking for sexual exploitation [34]. However, considering the cases reported to/by NGOs and official agencies, experts in this field estimate that the dark figures might be five times higher than official statistics report [35].

The "official data on human trafficking (TSH) in Portugal indicate a residual phenomenon, with approximately 80 cases reported each year on average, with a total of 250 victims in 2009, 2010 and 2011. Of these cases, less than $25 \%$ were confirmed (58)" ([11], p. 23). Regarding child trafficking, prior to 2010, national data were subsumed under the general data of human trafficking. Nonetheless, since national data on human trafficking began being collected, reports indicate that few children were victims of this type of crime (e.g. in 2008, the minimum age of the reported cases was 1 year old; in 2009, the minimum age was 12 years old). In accordance with the Report of the Group of Experts on Action against Trafficking in Human Beings [35], between 2008 and 2011, 17 children met this condition, the majority of whom were female (median age $=14$ years old). Sexual exploitation, labour exploitation $(n=3)$ and attempted adoption $(n=3)$ were the identified purposes of trafficking.

Table 1 details the number of child trafficking referrals considering the total number of human trafficking referrals in Portugal from 2010 to 2017. Data, 


\begin{tabular}{|c|c|c|c|c|c|c|c|c|}
\hline Year & 2010 & 2011 & 2012 & 2013 & 2014 & 2015 & 2016 & 2017 \\
\hline $\begin{array}{l}\text { No. of child } \\
\text { trafficking } \\
\text { referrals }\end{array}$ & $7^{1}$ & $10^{2}$ & $39^{3}$ & 49 & 27 & $18^{4}$ & 26 & $45^{5}$ \\
\hline $\begin{array}{l}\text { Total no. of } \\
\text { human trafficking } \\
\text { referrals }\end{array}$ & $86^{6}$ & $71^{7}$ & $125^{8}$ & 308 & 197 & $193^{9}$ & 261 & 175 \\
\hline $\begin{array}{l}\% \text { of child } \\
\text { trafficking } \\
\text { referrals }\end{array}$ & $8.1 \%$ & $14.1 \%$ & $31.2 \%$ & $15.9 \%$ & $13.7 \%$ & $9.3 \%$ & $9.9 \%$ & $25.7 \%$ \\
\hline $\begin{array}{l}{ }^{1} \text { Ref. [36] (first report } \\
{ }^{2} \text { Ref. [37]. } \\
{ }^{3} \text { Ref. [38]. } \\
{ }^{4} \text { Ref. [39]. } \\
{ }^{5} \text { Ref. [40]. } \\
{ }^{6} \text { Ref. [36]. } \\
{ }^{7} \text { Ref. [41]. } \\
{ }^{8} \text { Ref. [38]. } \\
{ }^{9} \text { Ref. [39]. }\end{array}$ & sagg & stat & $r c h$ & & & & & \\
\hline
\end{tabular}

Table 1.

Child trafficking referrals in Portugal (2010-2017).

compiled from different sources, represent cases reported before investigation and substantiation. Absolute figures are relatively low, both in relation to human trafficking in general and to child trafficking specifically; however, notable variations have been found over time. The percentage of child trafficking referrals varied from $8.1 \%$ in 2010 to $31.2 \%$ in 2012 .

According to Neves and Pedra [11], 82.4\% of the trafficked children in Portugal are 15 years or older. In addition, those who began to be trafficked in childhood tend to be exploited for longer periods than those who start the process in adulthood. In fact, $44 \%$ of trafficked children have been exploited longer than 4 years. According to these authors, if the criterion used to set the age of the victim is the beginning of trafficking, then this number would be approximately $30 \%$ of all cases of trafficking.

\section{An outline of the problem}

As Clemente [10] asserted, the introduction of the issue of human trafficking in Portugal was prompted by the need to transpose the international directives issued by the United Nations and the European Commission into national law. When Portugal adopted the United Nations Convention against Transnational Organized Crime and the additional Protocol to Prevent, Suppress and Punish Human Trafficking (especially with regard to women and children) in 2004, all legislative changes that followed have given rise to the definition and development of specific policies and procedures. National Plans against Human Trafficking have played a decisive role in the adoption of an integrated intervention strategy, combining interventions at different levels and multiple actors.

In 2007, the Portuguese authorities developed the first National Plan against Human Trafficking (2007-2010) (I PNCTSH) [31], which had four strategic domains: (1) to understand the phenomenon and disseminate information; (2) to prevent, elucidate and train; (3) to protect, support and integrate; and (4) to conduct criminal investigation and prosecute traffickers [31]. With regard to children, (i) they are recognized as being among the most vulnerable populations to human 
trafficking (along with women), particularly those living in poverty; (ii) trafficking is considered as a violation of their right to be free and protected; and (iii) victims trafficked for reasons of sexual and/or labour exploitation require special assistance and protection. Considering children's and youths' vulnerability, the I PNCTSH considers the following specific areas of intervention: (i) to educate children by promoting creative debates and activities in schools about human rights, children's rights and human trafficking and (ii) to support trafficked children by providing special measures to promote their rights and protection aiming at their global development.

This Plan led to the creation of the Observatory on Human Trafficking (OTSH) in 2008, which was established by Decree-law no. 229 on November 27, 2008. It is responsible for collecting, producing, processing and analyzing data on human trafficking, including child trafficking.

In 2009, two initiatives stood out in this domain [27]: (a) the certification of documents for foreign children attending Portuguese schools (Immigration and Borders Service $[\mathrm{SEF}$ ] goes to school) and (b) the creation of the first temporary shelter for 6- to 18-year-old refugee children and (CACR). This centre is expected to provide specialized assistance to children and youth in the asylum process (i.e. legal, social and psychological support).

The second National Plan against Human Trafficking (2011-2013) (II PNCTSH) [42] defined the same areas of intervention as the I PNCTSH. Nonetheless, the special situation of children was not differentiated in this Plan, neither conceptually nor in terms of specific measures.

In 2013, Portugal joined (a) the "European Cross-Actors Exchange Platform for Trafficked Children on Methodology Building for Prevention and Sustainable Inclusion", which aimed to develop an evidence-based intervention model targeting children who are vulnerable to trafficking and promote knowledge about criminal procedures concerning THB in the EU, and (b) the "Improving and Monitoring Protection Systems against Child Trafficking and Exploitation" (IMPACT) Project, which aimed to improve child protection and welfare policies to prevent and protect children, particularly those vulnerable to trafficking and exploitation [24].

The third National Plan (2014-2017) (III PNCTSH) [43] had five strategic areas: (1) prevent, inform, understand and investigate; (2) educate, train and capacitate; (3) protect, intervene and empower; (4) investigate criminality; and (5) cooperate. Regarding children, it included actions such as the development of education for children, adolescents and adults, as well as the development of protocols for the prevention, detection and protection of child victims of trafficking. The implementation of standardized care protocols for the identification, referral and intervention of victims of trafficking, among others, and for child victims of trafficking, in particular, by the National Health Service (NHS), was particularly important.

The fourth National Plan (2018-2021) (IV PNCTSH) [40] defined three strategic objectives: (i) to develop knowledge and raise awareness on THB, (ii) to improve the quality of interventions for trafficking victims, and (iii) to strengthen the fight against organized crime networks. With regard to children, an emphasis was put on the development of guidelines and protocols for intervening with children across different services as well as on reinforcing networking within different services, including the NHS and the National Network for the Support and Protection of Trafficking Victims.

As the four national plans against human trafficking show, children are included as victims of trafficking and are occasionally specifically targeted. However, none of the plans address the specificity of child trafficking. 


\section{The specificities of child trafficking}

The Portuguese Penal Code (Law no. 59/2007) defines child trafficking as enticing, transporting, harboring or housing a child or transferring, offering or accepting the child for the purpose of sexual exploitation, labour exploitation, begging, slavery, the removal of organs or adoption, among other criminal activities (Article 160) [24]. In fact, research shows that, most of the time, children are trafficked for labour exploitation (e.g. domestic servitude, agricultural labour, car washing, factory labour), sexual exploitation (e.g. prostitution, pornography and forced marriage), illegal adoption and criminal exploitation (e.g. cannabis cultivation, robbery, begging) [44].

As detailed, this definition entails the intentional action of the offender to exploit a vulnerable person. In the case of children, the critical elements of the definition of human trafficking do not apply [34]: the means (coercion, fraud or deception, abuse of power or of a position of vulnerability) and the victim's consent. However, the issue of consent is not exempted from controversy because of the debate concerning the age of consent [19], an issue related to the criterion used to set the age of the victim, as previously discussed.

Associated with age and the corresponding development level are, among others, the issues of: a) capacity to consent to their involvement in certain activities or relationships, especially those that are deviant or criminal; b) the responsibility inherent to this (in) capacity; c) the different developmental needs that children might exhibit depending on their age; d) their plasticity and vulnerability to the external world and the consequent and serious implications of their involvement in harmful relationships and activities; e) longer periods of exploitation than those of trafficked adults; and f) more support needed, given the higher likelihood to develop trauma.

As Greenbaum, Yun and Todres ([45], p. 161) argued, "Given the often multiple vulnerabilities leading to trafficking, the complex trauma experienced during (and sometimes before) the trafficking period, and the myriad adverse effects of exploitation, the needs of the child victim may be extensive and multi-faceted". In fact, the exploitation and trafficking of children are often associated with adverse experiences of abuse, neglect and other forms of violence that harm their physical and mental health. Empirical evidence indicates that between approximately onefourth and one-half of all trafficked children are victims of physical or sexual abuse $[26,46]$. These forms of maltreatment are associated with psychological disorders such as posttraumatic stress disorder, substance abuse, self-harming behaviour, suicide ideation/attempts, depression and various affective disorders and behavioral difficulties [26].

Thus, interventions must be multidimensional and address different groups and levels of victims' needs, not only those that result from trafficking but also those that are at its origin. Child trafficking shares with the other forms of human trafficking multiple, complex and systemic causes, especially specific structural features of the life contexts. Family dynamics are especially relevant for children: dysfunctional families, family abuse/neglect and violence are key variables [24]. Social and political factors such as poverty, social and economic exclusion, limited opportunities to pursue education, scarce and precarious employment, genderbased violence and social inequalities between countries and regions are also important enabling factors. Likewise, more distal elements, such as exploitative relationships, organized crime, illegal migration, corruption and armed conflict play key roles in this phenomenon [43]. 


\section{Child trafficking as a matter of child protection}

Child protection systems are the fundamental framework for providing assistance to child victims or those vulnerable to trafficking [20]. In Portugal, a victim of child trafficking is considered as at risk, falling under Protection Law no. 23/2017 and subject to the same assistance as any national child, regardless of nationality or type of risk. Any person identified as a victim of child trafficking should be reported to a public prosecutor who activates a protection measure.

Based on a review of 20 multinational projects funded by the European Commission on child victims of trafficking, including Portugal, Palmer [20] concluded that "trafficked children across Europe are not receiving the state care and protection that they, as children, are entitled to" (p. 7). This study showed the structural flaws in child protection services at three levels: victim detection, support and service coordination. In short, services fail to adjust their level and type of support to the specific needs of these children and youth, either initially, when detecting and referring cases, or in the provision of appropriate assistance. If in some cases a dominant concern exists with the child's immigration status that overrides the response to their needs, in others the response to these children's needs is subsumed within the generic provision available to all children at risk. Solutions range from those that compromise children's freedom to those that do not guarantee their protection or meet their needs, providing overly bureaucratic services. In these circumstances, child protection systems are more harmful than protective and can even facilitate the exploitation and trafficking of these children [47], actively compromising their rights.

Additionally, combating and preventing child trafficking requires a systemic approach in which communication among the health, education, welfare and justice systems is critical [20]. Regarding Portugal, international reports have mentioned the lack of standardized procedures and referral mechanisms [24].

Despite the recognition of the inclusive nature of health, education, welfare and justice sectoral policies, the status of children continues to determine the type of services and rights to which they have access. In accordance with experts, legislation is inclusive, but procedures are not, and the strategic planning and coordination of actions have flaws. However, others argue for the need for comprehensive laws to integrate the different policy domains, procedures and services [24].

Despite the centrality of the child protection system regarding child victims or those at risk of being trafficked, referrals in Portugal are made through two types of entities: criminal agencies (OPC) and NGOs and the Authority for Working Conditions (ACT). Regarding the OPC, the Immigration and Borders Service $(\mathrm{SEF})$ is responsible for detecting unaccompanied asylum-seeking children and for referring them to the Portuguese Refugee Council (CPR) [24] because it is assumed that they are vulnerable to trafficking [19]. The identification of a case triggers its referral for criminal investigation and court proceedings [24]. After referral, the cases proceed through an assessment process during which they can be classified as confirmed, not confirmed or under investigation. This assessment is complex. Usually a panoply of related offenses exist whose legal distinction is challenging, such as aid to illegal immigration, recruitment of illegal labour, kidnapping, slavery, sham marriages/marriages of convenience, counterfeit and false documents, criminal association, domestic violence or violation [36] and smuggling [12]. This procedure confirms, once again, the police and security framing of an essentially sociopolitical phenomenon.

A common reference in the literature on this topic is the need for the specific training of practitioners who, at different levels, work with and for children, especially those with child victims or children at risk of being trafficked to identify and 
provide the necessary and appropriate assistance. Immigration officers and other police forces are the frontline staff in most of the national referral mechanisms in Europe. Experts contend that the adequate training of these professionals is critical to ensure that victims are correctly identified and receive appropriate support [19], including cooperation with relevant agencies. In addition to these officials [24], from a comprehensive perspective, teachers [32] and healthcare professionals [48] would benefit from training to identify the signs of exploitation and effectively intervene.

\section{Conclusion: what to do with a problem of human beings that is not perceived as a social problem?}

Following Pinto et al. [13], child trafficking is not merely a "distant history" taught in school, but it is also geographically and sociologically distant, as portrayed by the media, and a distant interest for research. Law, politics/public administration, research and education are key instruments for fostering the social appreciation of this problem.

The law is a fundamental constituent of society; it is based on justice and is a driver of awareness. Retrospectively, it reflects social and cultural historicity. Looking forward, however, the law sets the standards for behaviour within a culture and promotes psychosocial adjustment. In this sense, legal changes, under international agreements, build an ethical mindset based on human rights that is progressively shared by populations. Education, training and social pedagogy for the community, their organizations and the media must be an ongoing and relentless social task to create a relational culture that is inclusive, rights-based and culturally sensitive.

Child trafficking results from the failure to protect children and safeguard their rights. It is thus a failure towards all children. Protection should be a systemic and ecological feature of the contexts of children's lives. Additionally, the response to the various needs of each and every child should be the primary concern of children's services and programmes. For this purpose, instead of a policymaking approach based on a patchwork of scattered and partial measures, we need effective and integrated public policies, particularly child and family policies, informed by rigorous and systematic research. Moreover, the proliferation of plans with goals insufficiently developed and evaluated should give way to a cohesive national antichild trafficking approach.

The identification of the child victims of trafficking is a critical condition for the provision of the appropriate support. The gaps observed in most EU countries, including Portugal [20], led the experts to recommend the revision of the criteria and thresholds to be eligible for the child protection system. With respect to Portugal, the Protection Law, based on the distinction between risk and danger, excludes from the threshold for referral children in low-risk situations. In these conditions, the probability of not detecting potential victims of trafficking is not negligible [20]. Therefore, within a broader perspective of the concept of child protection, we endorse the revision of these thresholds and the consideration of different levels of intervention according to the level of risk identified.

Another crucial aspect of the intervention is the first service with which the child victims come into contact for the first time because it determines the subsequent provision made available to them. Regarding children at risk, the interaction among the services involved (e.g. health, education, Immigration and Borders Service, criminal justice, labour), should occur, in any situation, under the 
coordination of the Child Protection System, regardless of the specific status of the child (e.g. immigration status).

These changes will lead to the cultural shift [16] necessary to assign importance to the big and small issues of our time, regardless of the condition of the people affected, their age or number, so that a problem that affects other people is, by definition, a social problem.

\section{Acknowledgements}

This study had the financial support of Research Centre on Child Studies (CIEC), by the Strategic Project UID/CED/00317/2013, through the National Funds through the Foundation for Science and Technology (FCT) and co-financed by European Regional Development Funds (FEDER) through the Competitiveness and Internationalization Operational Program (POCI) with the reference POCI-01-0145-FEDER-007562.

\section{Conflict of interest}

The authors declare no conflict of interest.

\section{Author details}

Paula Cristina Martins

Research Centre on Child Studies (CIEC), University of Minho (UM), Braga, Portugal

*Address all correspondence to: pcmartins@psi.uminho.pt

\section{IntechOpen}

(C) 2020 The Author(s). Licensee IntechOpen. This chapter is distributed under the terms of the Creative Commons Attribution License (http://creativecommons.org/licenses/ by/3.0), which permits unrestricted use, distribution, and reproduction in any medium, provided the original work is properly cited. (cc) BY 


\section{References}

[1] Rubington E, Weinberg MS. The Study of Social Problems: Seven Perspectives. 7th ed. New York, NY: Oxford University Press; 2010

[2] Best J. Social progress and social problems: Toward a sociology of gloom. Sociological Quarterly. 2001;42(1):1-12

[3] Sharapov K. Understanding Public Knowledge and Attitudes towards Trafficking in Human Beings Research Paper. Part 1. Budapest: Center for Policy Studies, Central European University; 2014. Retrieved from: http://webcache.googleusercontent. $\mathrm{com} /$ search?q=cache:IfbjThK2OIJ:lastradainternational.org/ lsidocs/3119-Public-knowledgeand-attitudes-towards-thb-2014. $\mathrm{pdf}+\& \mathrm{~cd}=1 \& \mathrm{hl}=\mathrm{pt}-\mathrm{PT} \& \mathrm{ct}=\mathrm{clnk} \& \mathrm{gl}=\mathrm{pt}$

[4] Sharapov K. Sharapov 2014. Understanding Public Knowledge and Attitudes towards Trafficking in Human Beings Research Paper. Part 2. Budapest: Center for Policy Studies, Central European University; 2015. Retrieved from: https://cps.ceu.edu/sites/cps.ceu. edu/files/cps-working-paper-upkatpublic-knowledge-and-attitudestowards-thb-2015.pdf

[5] Sani A, Nunes L, Caridade S. Relatório Tráfico de Seres Humanos. Porto: Fundação Fernando Pessoa; 2016

[6] Peixoto J, Soares A, Costa P, Murteira S, Pereira S, Sabino C. O tráfico de migrantes em Portugal: Perspectivas sociológicas, jurídicas e políticas. 2005. Retrieved from: http://www.oi.acidi.gov.pt/docs/ Estudos\%20OI/Estudo_OI_12.pdf

[7] Couto D, Machado C, Martins C, Gonçalves R. A construção mediática do tráfico de seres humanos na imprensa escrita portuguesa. Análise Psicológica. 2012;30(1-2):231-246
[8] European Commission (EC). Study on High-Risk Groups for Trafficking in Human Beings. Final Report. Luxembourg: Publications Office of the European Union; 2015. Retrieved from: https://ec.europa.eu/anti-trafficking/ sites/antitrafficking/files/study_on_ children_as_high_risk_groups_of_ trafficking_in_human_beings_0.pdf

[9] Kangaspunta K, Clark M, Dixon J, Dottridge M. An Introduction to Human Trafficking: Vulnerability, Impact and Action. New York: UN Office on Drugs and Crime; 2008

[10] Clemente M. Human trafficking in Portugal: An ethnography of research and data. Studi emigrazione. International Journal of Migration Studies. 2017;208:663-686

[11] Neves M, Pedra C. A Proteção dos Direitos Humanos e as Vítimas do Tráfico de Pessoas - Rotas, Métodos, Tipos de Tráfico e Setores de Atividade em Portugal. Lisboa: IEEI; 2012

[12] Derluyn I, Broekaert E. On the way to a better future: Belgium as a transit country for trafficking and smuggling of unaccompanied minors. International Migration. 2005;43(4):31-53

[13] Pinto R, Valente I, Guia M. The frequency of the subject "trafficking of people" in master's dissertations and doctoral thesis available in the "estudo geral da uc" (2006-2016). Debater a Europa. 2017;17:75-96

[14] Martins P. ${ }^{1}$ Children as victims and as perpetrators: From symbolic incongruence to ineffective practice. In: Sharma V, Brink A, editors. Childhood through the Looking Glass. Oxford: Interdisciplinary Press; 2016. pp. 49-60

[15] Stryker R. Violent children and structural violence: Re-signaling 'RAD kids' to inform the social work 
professions. Children and Youth

Services Review. 2013;35(8):1182-1188

[16] Gearon A. Child trafficking: Young people's experiences of front-line Services in England. The British Journal of Criminology. 2019;59(2):481-500.

DOI: $10.1093 /$ bjc/azy042

[17] UNICEF. The State of the World's Children. Excluded and Invisible. Unicef House: New York; 2006

[18] Norgaard K. We don't really want to know: Environmental justice and socially organized denial of global warming in Norway. Organization and Environment. 2006;19:347-370. DOI: 1086026606292571

[19] Westwood J. The social construction of risk in child trafficking discourses: A study of melodramatic tactics in child trafficking narratives [doctoral thesis]. 2010. Retrieved from: http://clok.uclan. ac.uk/3717/3/Westwood\%20Joanne\%20 Final\%20e-Thesis\%20 (Master\%20 Copy).pdf

[20] Palmer E. Trafficked children and child protection systems in the European Union. European Journal of Social Work. 2019;22(4):551-562. DOI: 10.1080/13691457.2018.1441134

[21] Crawley H. Child first, migrant second: ensuring that every child matters. Immigration Law Practitioners Association. 2006. Available from: http://www.ilpa.org.uk/ [Accessed: April 20, 2007]

[22] Cunningham S, Tomlinson J. Starve them out: Does every child really matter? A commentary on section 9 of the asylum and immigration (treatment of claimants, etc.) act, 2004. Critical Social Policy. 2005;25(2):253-275

[23] Lorenz W. European policy developments and their impact on social work. European Journal of Social Work. 2017;20(1):17-28
[24] IMPACT. IMPACT - Melhorar e Monitorizar os Sistemas de Proteção Contra o Tráfico e a Exploração de Crianças. 2014. Relatório Transnacional. Retrieved from: https://www. cesis.org/admin/modulo_news/ ficheiros_noticias/201404011010211impactrelatoriotransnacional.pdf

[25] Perista P, Brázia A. (s/d). Sistemas de proteção e bem-estar das crianças: que impactos no assegurar de direitos e na proteção contra o tráfico e a exploração? Retrieved from: https:// www.cesis.org/site/upload/Artigo_Siste maProte\%C3\%A7\%C3\%A3oBemEstard asCrian\%C3\%A7as.pdf [Accessed: April 17, 2019]

[26] Ottisova L, Smith P, Shetty H, Stahl D, Downs J, Oram S. Psychological consequences of child trafficking: An historical cohort study of trafficked children in contact with secondary mental health services. PLoS One. 2018;13(3):e0192321. DOI: 10.1371/ journal.pone.0192321

[27] RASI. Relatório Anual de Segurança Interna 2009. Ministério da Administração Interna. 2009. Retrieved from: http://www.ansr.pt/ InstrumentosDeGestao/Documents/ Relat\%C3\%B3rio\%20Anual\%20de\%20 Seguran\%C3\%A7a\%20Interna\%20 (RASI)/RASI\%202009.pdf

[28] ECPAT. Joint East West Research on Trafficking In Children for Sexual Purposes in Europe: The Sending Countries. 2004. Retrieved from: http://lastradainternational.org/ lsidocs/223\%20Joint\%20east\%20 west\%20research\%20(ECPAT.pdf [Accessed: April 25, 2019]

[29] Catch and Sustain. Anti-Trafficking Intervention Programme Targeted to Vulnerable Children. Luxembourg: European Federation for Street Children; 2015

[30] UNODC. The Evolution of the UNODC Global Report on Trafficking in 
Persons. 2019. Retrieved from: https:// delta87.org/2019/02/evolution-unodcglobal-report-trafficking-in-persons/ [Accessed: April 25, 2019]

[31] I National Plan for Preventing and Combating Trafficking in Human Beings (I PNCTSH) (2007-2010). Resolução do Conselho de Ministros no. 81/2007. Diário da República, 1 . $^{\mathrm{a}}$ série - No. 119 - 22 de Junho de 2007. Retrieved from: https://www. otsh.mai.gov.pt/wp-content/uploads/ TSH-I_Plano_Nacional.pdf

[32] UNODC. 2018 Global Report on Trafficking in Persons. New York: United Nations; 2018. Retrieved from: https://www.unodc.org/documents/ data-and-analysis/glotip/2018/ GLOTiP_2018_BOOK_web_small.pdf

[33] ILO. ILO Global Estimate of Forced Labour: Results and Methodology. Geneva: ILO; 2012

[34] European Commission (EC). Data Collection on Trafficking in Human Beings in the EU. Final Report - 2018. Brussels. 2018. DOI: 10.2837/193237. Retrieved from: https://ec.europa.eu/ home-affairs/sites/homeaffairs/files/ what-we-do/policies/european-agendasecurity/20181204_data-collectionstudy.pdf

[35] GRETA. Report Concerning the Implementation of the Council of Europe Convention on Action against Trafficking in Human. 2013. Retrieved from: https://www.legislationline.org/ documents/id/18620 [Accessed: April 18, 2019]

[36] Observatório do Tráfico de Seres Humanos (OTSH). Annual Statistical Report on THB 2009. 2010. Retrieved from: https://www.otsh.mai.gov.pt/ wp-content/uploads/REC-OTSH_ Relatorio_Anual_TSH_2009.pdf

[37] Observatório do Tráfico de Seres Humanos (OTSH). Annual Statistical
Report on THB 2010. 2011. Retrieved from: https://www.otsh.mai.gov.pt/ wp-content/uploads/REC-OTSH_ Relatorio_Anual_TSH_2010.pdf

[38] RASI. Relatório Anual de Segurança Interna 2012. Ministério da Administração Interna. 2012.

Retrieved from: http://www.ansr.pt/ InstrumentosDeGestao/Documents/ Relat\%C3\%B3rio\%20Anual\%20de\%20 Seguran\%C3\%A7a\%20Interna\%20 (RASI)/RASI\%202012.pdf

[39] RASI. Relatório Anual de Segurança Interna 2015. Ministério da Administração Interna. 2015. Retrieved from: http://www.ansr.pt/ InstrumentosDeGestao/Documents/ Relat\%C3\%B3rio\%20Anual\%20de\%20 Seguran\%C3\%A7a\%20Interna\%20 (RASI)/RASI\%202015.pdf

[40] IV National Plan for Preventing and Combating Trafficking in Human Beings (IV PNCTSH) (2018-2021). Resolução do Conselho de Ministros no. 80/2018. Diário da República, 1 . $^{\mathrm{a}}$ série - No. 116 - 19 de junho de 2018. Retrieved from: https://www.otsh.mai. gov.pt/wp-content/uploads/TSH-IV_ Plano_Nacional.pdf

[41] RASI. Relatório Anual de Segurança Interna 2011. Ministério da Administração Interna. 2011.

Retrieved from: https://www.dn.pt/ DNMultimedia/DOCS+PDFS/relatorio. pdf

[42] II National Plan for Preventing and Combating Trafficking in Human Beings (II PNCTSH) (2011-2013). Resolução do Conselho de Ministros no. 94/2010. Diário da República, 1. ${ }^{\mathrm{a}}$ série - No. 231 - 29 de Novembro de 2010. Retrieved from: https://www. otsh.mai.gov.pt/wp-content/uploads/ TSH-II_Plano_Nacional.pdf

[43] III National Plan for Preventing and Combating Trafficking in Human Beings (III PNCTSH) (2014-2017). 
Resolução da Assembleia da República no. 156/2013. Diário da República, 1 a $^{a}$ série - No. 253 - 31 de dezembro de 2013. Retrieved from: https://www.otsh. mai.gov.pt/wp-content/uploads/TSHIII_Plano_Nacional.pdf

[44] Stanley N, Oram S, Jakobowitz S, Westwood J, Borschmann R, Zimmerman C, et al. The health needs and healthcare experiences of young people trafficked into the UK. Child Abuse and Neglect. 2016;59:100-110

[45] Greenbaum V, Yun K, Todres J. Child trafficking: Issues for policy and practice. The Journal of Law, Medicine and Ethics. 2018;46:159-163. DOI: $10.1177 / 1073110518766029$

[46] Kiss L, Yun K, Pocock N, Zimmerman C. Exploitation, violence, and suicide risk among child and adolescent survivors of human trafficking in the Greater Mekong Subregion. JAMA Pediatrics. 2015;169(9):1-8. DOI: 10.1001/ jamapediatrics

[47] GATE. Guardians Against Child Trafficking and ExploitationEuropean Report. Italy: KMOP and Defence for Children International; 2013

[48] Greenbaum J, Bodrick N. Global human trafficking and child victimization. Pediatrics. 2017;140(6):e20173138 



\section{Edited by Jane Reeves}

This edited volume, Modern Slavery and Human Trafficking, is a collection of reviewed and relevant research chapters, offering a comprehensive overview of recent developments in the field of modern slavery and human trafficking. The book comprises single chapters authored by various researchers and edited by an expert active in the aforementioned research area. Each chapter is complete in itself but united under a common research study topic. This publication aims at providing a thorough overview of the latest research efforts by international authors on modern slavery and human trafficking, and opening new possible research paths for further novel developments. 